\title{
ATIVIDADE ANTIFÚNGICA DE METABÓLITOS SECUNDÁRIOS PRODUZIDOS PELO ENDÓFITO DE MANDIOCA Bacillus pumilus MAIIIM4a
}

\section{FLÁVIA MANDOLESI PEREIRA DE MELO}

Dissertação apresentada a Escola Superior de Agricultura

"Luiz de Queiroz", Universidade de São Paulo, para obtenção do título de Mestre em Agronomia, Área de Concentração: Microbiologia Agrícola.

P I R A C I C A B A

Estado de São Paulo - Brasil

Maio - 2005 


\title{
ATIVIDADE ANTIFÚNGICA DE METABÓLITOS SECUNDÁRIOS PRODUZIDOS PELO ENDÓFITO DE MANDIOCA Bacillus pumilus MAIIIM4a
}

\author{
FLÁVIA MANDOLESI PEREIRA DE MELO
}

Licenciatura e Bacharelado em Ciências Biológicas

Orientadora: Profa. Dra. MARLI DE FÁTIMA FIORE

Dissertação apresentada à Escola Superior de Agricultura "Luiz de Queiroz", Universidade de São Paulo, para obtenção do título de Mestre em Agronomia, Área de Concentração: Microbiologia Agrícola.

P I R A C I C A B A

Estado de São Paulo - Brasil

Maio - 2005 
Dados Internacionais de Catalogação na Publicação (CIP) DIVISÃO DE BIBLIOTECA E DOCUMENTAÇÃO - ESALQ/USP

Melo, Flávia Mandolesi Pereira de

Atividade antifúngica de metabólitos secundários produzidos pelo endófito de mandioca Bacillus pumilus MAIIIM4a/ Flávia Mandolesi Pereira de Melo. - - Piracicaba 2005.

84 p. : il.

Dissertação (mestrado) - - Escola Superior de Agricultura Luiz de Queiroz, 2005. Bibliografia.

1. Antifúngico 2. Bactéria endofítica 3. Controle biológico (Fitossanidade) 4. Fungo fitopatogênico 5. Mandioca 6. Microbiologia 7. Microscopia eletronônica de varredura I. Título

CDD 633.4

"Permitida a cópia total ou parcial deste documento, desde que citada a fonte - O autor" 


\section{Dedico}

Aos meus queridos PAIS Eduardo Pereira de Melo e Giselle Mirian Mandolesi de Melo, pelo intenso amor, carinho com que me ensinaram a viver, pelo apoio, incentivo, pela minha formação, por dedicarem suas vidas aos seus filhos, pôr serem exemplos de vida e por acreditarem em mim.

Aos meus irmãos Fabiano, Francine e Fernanda Mandolesi P. de Melo, pelo carinho, pela amizade, paciência, apoio em todos os momentos e pela FELICIDADE de tê-los como IRM ÃOS.

\section{OFERECO}

Ao meu namorado Fabiano Silva Romão por todo o amor, por todo o apoio e pelo exemplo de bondade, correção e dedicação.

\section{Amo muito vocês!!!!!!}




\section{Agradecimentos especiais}

- A Deus, pela minha existência e por estar sempre ao meu lado;

- Aos meus pais, Eduardo e Giselle, por todo amor e apoio, por serem tão especiais e pelo privilégio de ser sua filha:

- Aos meus queridos irmãos, Fabiano, Francine e Fernanda, pela paciência, carinho, compreensão e pelo amor que sempre tiveram comigo:

- Ao meu namorado Fabiano Silva Romão pelo amor, carinho, paciência e por acreditar sempre em mim:

- Á Dra. Shirlei Scramin, pela orientação e amizade. Um exemplo de competência e companheirismo. Pessoa por quem tenho admiração e carinho:

- Ao Prof. Dr. Itamar Soares de Melo pela confiança e amizade desde minha graduação e principalmente pela orientação, a qual contribuiu para meu crescimento profissional e pessoal;

- Á Profa. Dra. Marli de Fátima Fiore pela orientação, carinho, amizade, pelas valiosas sugestões e competência profissional; 
- Aos grandes amigos Luiz Alberto Moraes e Raquel sempre dispostos a ajudar, pelas sugestões, longas conversas, pela competência profissional, a qual admiro muito e principalmente, pela nossa sincera amizade;

- Aos meus grandes amigos Francine (irmã), Nyvea, Graziela, Felipe Tosta Moura e João, por todos os ótimos momentos que tivemos nesses anos de convívio, pela paciência, apoio, carinho, festas, pela ajuda profissional e principalmente pela sólida amizade:

- Á Embrapa Meio Ambiente, nas pessoas em que me apoiaram e as quais, sempre me despertaram profunda admiração, Irene Schio, César de Rosso, Hugo de Souza, Alexandre Sereda, Wagner Portes, Dagmar Oliveira, Hiran Carvalho, Angela Valente e Rosely dos Santos, pela agradável convivência e exemplo de competência:

- A Prof. ${ }^{a}$ Dr. ${ }^{a}$ Maria Magali S.R. Soares, pelo incentivo, apoio e carinho, e por terem sido as principais incentivadoras da minha entrada na carreira científica:

- Á Profa Dra. Márcia Ortiz do Instituto Agronômico de Campinas (IAC), pelo auxílio e apoio nesta tese:

- Aos Docentes que participaram da Banca de Qualificação, Dr. Wellington Araújo, Profa. Dra. Aline Kleiner e Profa. Dra. Regina Monteiro, pelas valiosas sugestões; 
- Ao Laboratório Thompson-Unicamp onde realizei minhas análises químicas e onde fui tão bem acolhida:

- Aos técnicos do Laboratório de Química de Produtos Naturais, Hugo Leonardo, César de Rosso e Helena sempre dispostos a ajudar e pelo excelente profissionalismo;

- À Maria Amélia de T. Leme e Victor Simão, pelas revisões, correções da bibliografia, pela simpatia e disposição:

- A todos os funcionários, estagiários e terceirizados da Embrapa Meio Ambiente, por todo o incentivo, carinho e pela grande amizade nesses anos;

- A Empresa Brasileira de Pesquisa Agropecuária - Centro Nacional de Pesquisa e Avaliação do Impacto Ambiental (Embrapa- Meio Ambiente), em Jaguariúna-SP, por ceder-me o Laboratório de Química de Produtos Naturais, Microbiologia Ambiental, Fitopatologia para a realização dos experimentos;

- A todos os amigos que direta ou indiretamente influenciaram neste trabalho. 


\section{SUMÁRIO}

Página

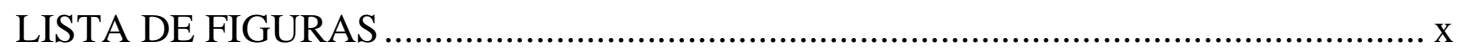

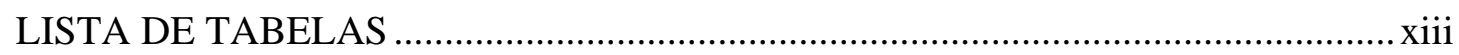

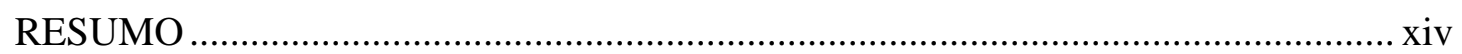

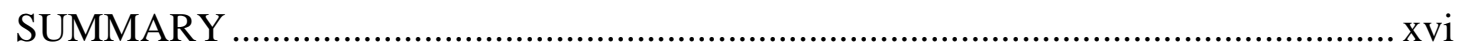

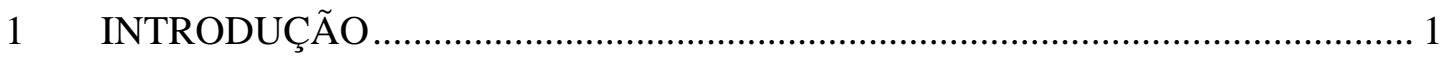

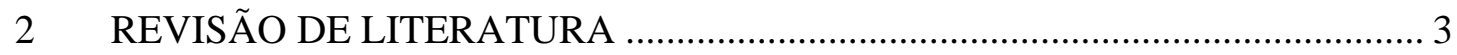

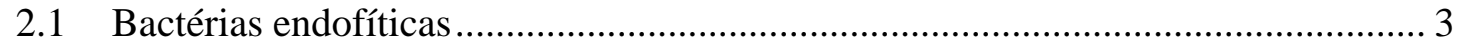

2.2 Diversidade de bactérias endofíticas .................................................................... 4

2.3 Efeitos benéficos de bactérias endofíticas nas plantas ............................................ 6

2.4 Controle Biológico de fungos fitopatogênicos por bactérias endofíticas ................. 9

2.4.1 Bactérias para o controle de Pragas na Agricultura............................................... 10

2.5 Gênero Bacillus como endófito de mandioca........................................................ 12

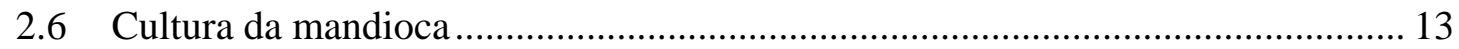

2.7 Metabólitos antifúngicos produzidos por Bacillus .............................................. 14

2.8 Métodos cromatográficos para identificações de substâncias ............................... 15

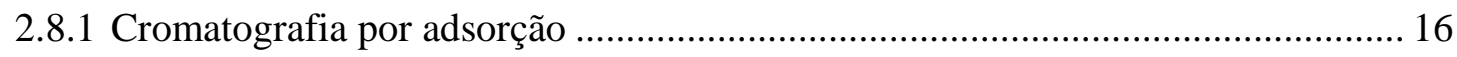

2.8.2 Cromatografia em Camada Delgada (CCD) ..................................................... 17

2.8.3 Cromatografia Gasosa Acoplada ao Espectrômetro de Massas ............................. 18

2.8.4 Cromatografia líquida acoplada ao espectrômetro de massas (CL/EM) .............. 19

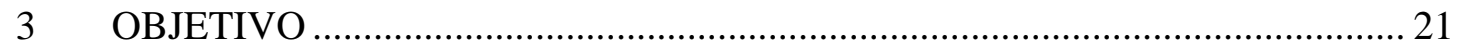

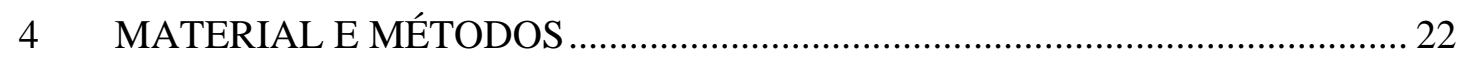

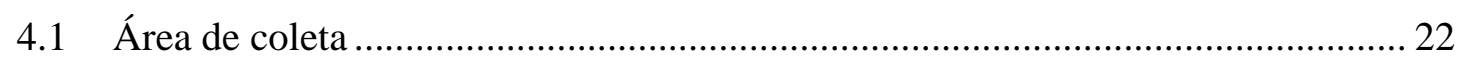

4.2 Isolamento das Bactérias endofíticas da mandioca ................................................ 22

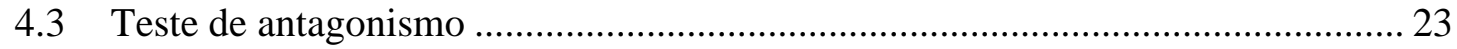

4.4 Triagem das melhores linhagens com ação antagonista ........................................ 23

4.5 Identificação da bactéria endofítica utilizando o gene 16S rDNA ......................... 24 
4.6 Identificação da bactéria selecionada por análise de ácidos graxos ...................... 25

4.7 Análise de Biomassa do Bacillus pumilus .......................................................... 26

4.8 Obtenção de extratos orgânicos de Bacillus pumilus ............................................ 26

4.9 Teste de Antibiose utilizando-se os extratos EB-1, EB-2 e EB-3 ......................... 27

4.10 Análise dos extratos orgânicos das bactérias endofíticas por métodos

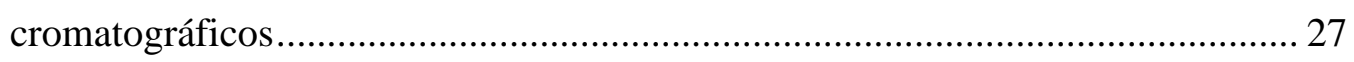

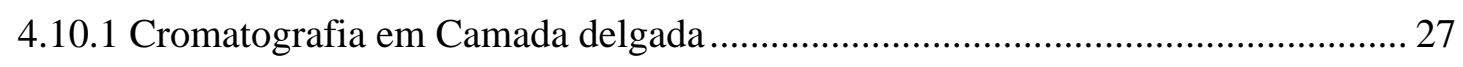

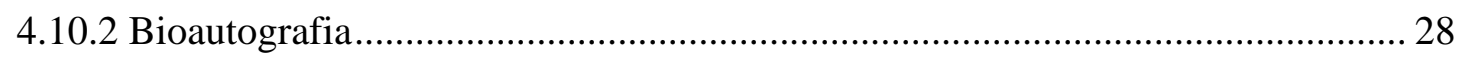

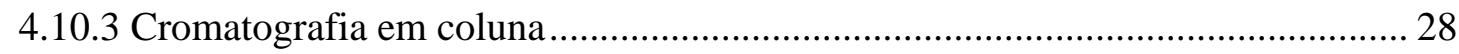

4.10.4 Derivatização das amostras dos extratos brutos com Diazometano $\left(\mathrm{CH}_{2} \mathrm{~N}_{2}\right)$

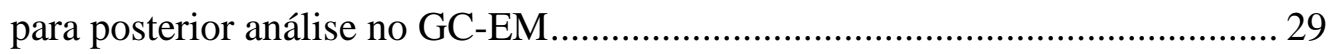

4.10.5 Preparação do Diazometano............................................................................... 29

4.10.6 Metilação dos extratos com Diazomentano ........................................................... 30

4.10.7 Análise por cromatografia gasosa acoplada ao espectrômetro de massa

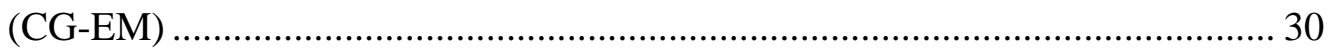

4.10.8 Cromatografia Líquida acoplada ao espectrômetro de massas ............................. 31

4.11 Inoculação da suspensão de Bacillus pumilus em plantas de mandioca obtidas

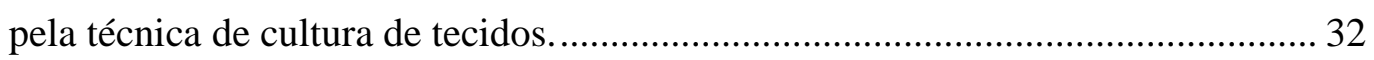

4.11.1 Preparação da amostra para microscopia eletrônica. ............................................ 34

4.11.2 Solução Karnovksy modificado (Técnica padrão segundo Kitajima \&

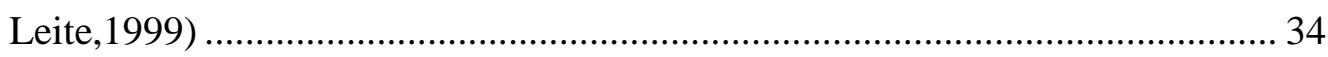

4.12 Resistência do Bacillus pumilus a diferentes antibióticos em diferentes

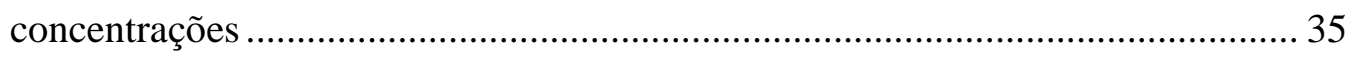

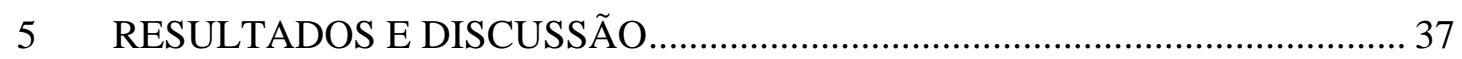

5.1 Coleta e isolamento de bactérias endofíticas de mandioca................................... 37

5.2 Métodos de identificação utilizando perfil de ácidos graxos (FAME) e o

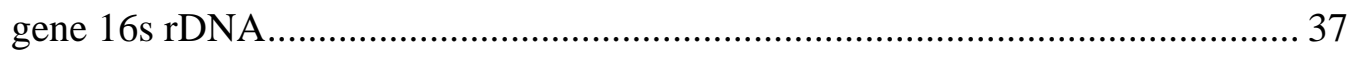

5.3 Colonização das bactérias endofítcas em diferentes partes da mandioca............... 41

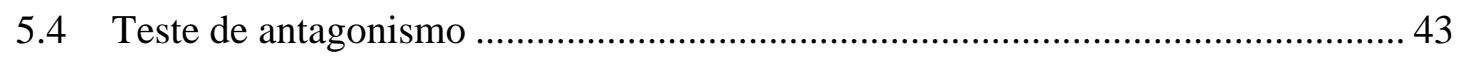


5.5 Cinética de crescimento da bactéria B. pumilus .................................................. 45

5.5.1 Produção de biomassa de B. pumilus em diferentes meios de cultura.................... 45

5.6 Extração de metabólitos secundários de B. pumilus, MAIIIM4a ........................... 49

5.7 Estudos dos metabólitos secundários produzidos por Bacillus pumilus, MAIIIM4a por diferentes métodos de análise......................................................50

5.7.1 Cromatografia em camada Delgada (CCD) ................................................... 50

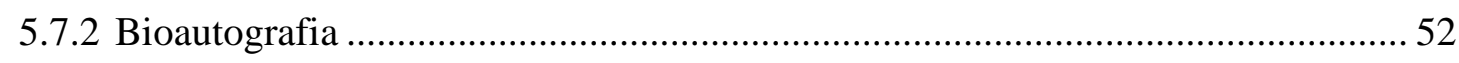

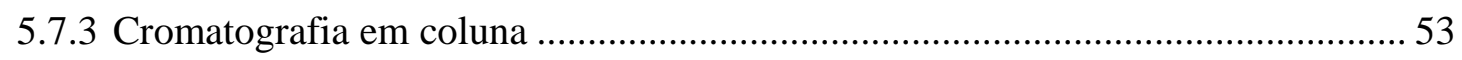

5.7.4 Cromatografia gasosa acoplada ao espectrômetro de massas................................. 53

5.7.5 Cromatografia líquida acoplada ao espectrômetro de massas (LC-EM/EM) ........ 55

5.8 Obtenção de mutantes da bactéria B. pumilus resistentes a antibióticos. .............. 60

5.9 Colonização de B. pumilus em raízes, manivas, e folhas da mandioca in vitro .... 61

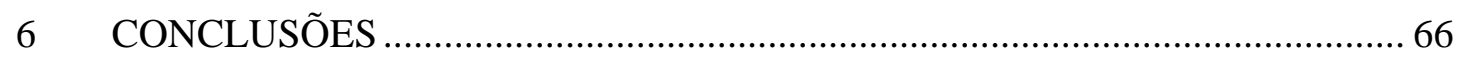

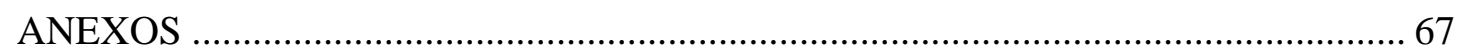

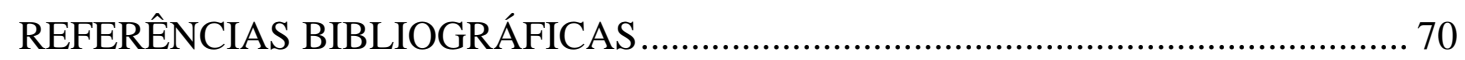




\section{LISTA DE FIGURAS}

1 Casa de farinha dos índios Ticunas na aldeia Patauá, próximo ao rio Manacapuru na Amazônia, onde foram feitas coletas de etnovariedades de mandioca

2 Extração dos metabólitos secundários da bactéria selecionada com diferentes solventes: hexano, dicloromentano e acetato de etila

3 Frações coletadas pela técnica de cromatografia em coluna

4 Equipamento utilizado na preparação do diazometano .30

5 Planta de mandioca cultivada em meio MS (MURASHIGE, T \& SKOOG)

6 Transferência da planta do meio sólido, limpeza das plantas com água esterilizada e inoculação das plantas em meio MS líquido

7 Inoculação de $10^{8}$ cels/mL da bactéria no meio MS líquido para posterior observação da colonização nas diferentes partes da planta

8 Secção das amostras em fragmentos pequenos (2x2) e fixadas em solução Karnovksy modificado

9 Dendograma baseado na composição de ácidos graxos das bactérias do gênero Bacillus.

10 Relações filogenéticas entre a seqüência parcial de 16S rRNA do endofítico B. pumilus MAIIIM4a e de outras linhagens de Bacillus retiradas do GenBank 
11 Padrão típico de crescimento de uma cultura bacteriana em sistema fechado .46

12 Biomassa em meio de cultura TS em diferentes tempos de incubação .46

13 Biomassa em meio de cultura KB em diferentes tempos de incubação .47

14 Biomassa em meio de cultura BD em diferentes tempos de incubação

15 Determinação de biomassa em meio de cultura CN em diferentes tempos de incubação .48

16 Média da biomassa de todos os meios de cultura, TS, CN, BD e KB em diferentes tempos de incubação .48

17 Teste de antibiose frente ao fitopatógeno $P$. aphanidermatum com os extratos em diclorometano, em acetato de etlia, em hexano e o controle respectivamente .50

18 Cromatografia em camada delgada utilizando os diferentes extratos da bactéria e também o controle, placa visualizada em câmara de UV com dois comprimentos de ondas (254/366nm)

19 Espectros de eletrospray (ESI) do pumilacidina: a) modo negativo e b) modo positivo .56

20 Espectros ms/ms de fragmentação induzida por colisão (CID) dos pumilacidina, a) CID do composto $\mathrm{m} / \mathrm{z}$ 1079.1; b) cid do composto $\mathrm{m} / \mathrm{z}$ 1065.0; c) cid do composto m/z 1051.0 e d) CID do composto m/z 1037.0...... .56 
21 Expansão dos espectros ms/ms de fragmentação induzida por colisão (CID) dos pumilacidina

22 Expansão dos espectros ms/ms de fragmentação induzida por colisão (CID) dos pumilacidina

23 Expansão dos espectros ms/ms de fragmentação induzida por colisão (CID) dos pumilacidina

24 Expansão dos espectros ms/ms de fragmentação induzida por colisão (CID) dos pumilacidina .58

25 Valores calculados e observados para o pumilacidina c16.

26 Sequência de aminoácidos ligados a uma cadeia de ácidos graxos pumilacidina $\mathrm{m} / \mathrm{z} 1051.0$ (c16)

27 Pumilacidina, metabólito antifúngico produzido pelo Bacillus pumilus, estrutura cíclica

28 Caracterização estrutural e sequenciamento dos aminoácidos para o pumilacidina $\mathrm{m} / \mathrm{z} 1051.0$

29 Microscopia eletrônica de varredura na região do caule

30 Microscopia eletrônica de varredura na região da raiz.

31 Microscopia eletrônica de varredura na região do caule da raiz .... .65 


\section{LISTA DE TABELAS}

1 Bactérias endofíticas isolados de variedades selvagens de mandioca da Amazônia........37

2 Identificação de algumas bactérias endofíticas, por FAME e por análise do de

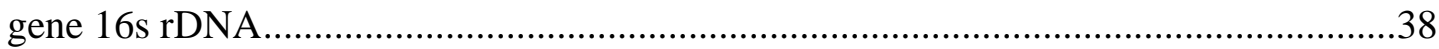

2.1 Análise da linhagem MAIIIM4a pela técnica de análise de ácidos graxos .39

3 Gêneros de bactérias endofíticas identificados de diferentes partes da planta de mandioca, na Amazônia .43

$4 \quad$ Triagem das bactérias pelo teste de antagonismo frente ao patógeno Pythium aphanidermatum

5 Inibição do crescimento miceliano de fungos fitopatogênicos por bactérias endofíticas, isoladas de mandioca

6 Avaliação da atividade dos diferentes extratos de B. pumilus sobre os fungos fitopatogênicos R. solani, P. aphanidermatum e S. rolfsii.

7 Rfs das frações dos extratos visualizadas sob lâmpada UV com dois comprimentos de onda 254/366 nm

8 Resultados dos testes de bioautigrafia com os extratos da bactéria MAIIIM4a que apresentaram atividade antifúngica .52

9 Substâncias identificadas no extrato hexânico utilizando CG/EM .54

10 Substâncias identificadas no extrato diclorometano utlizando CG/EM . .54

11 Substâncias identificadas no extrato acetato de etila utilizando CG/EM... .55

12 Resistência da bactéria MAIIIM4a, a diferentes concentrações de antibióticos 61 


\title{
ATIVIDADE ANTIFÚNGICA DE METABÓLITOS SECUNDÁRIOS PRODUZIDOS PELO ENDÓFITO DE MANDIOCA Bacillus pumilus MAIIIM4a
}

\author{
Autora: FLÁVIA MANDOLESI PEREIRA DE MELO \\ Orientadora: Dra. MARLI DE FÁTIMA FIORE
}

\section{RESUMO}

Microrganismos endofíticos são definidos como organismos que habitam em pelo menos durante um período de seu ciclo vital, o interior de um vegetal, sem causar aparentemente nenhum dano a este. Na busca de novos organismos e novos metabólitos secundários, um estudo foi conduzido visando avaliar a diversidade química de bactérias endofíticas por meio do isolamento e identificação de metabólitos secundários produzido por bactérias endofíticas de etnovariedades de mandioca, mantidas por tribos indígenas da Amazônia brasileira. Sessenta e sete bactérias endofíticas de mandioca foram selecionadas e submetidas à uma seleção através de testes de antagonismo in vitro. A bactéria endofítica, Bacillus pumilus foi a que apresentou forte ação inibitória contra os fitopatógenos Rhizoctonia solani, Pythium e Sclerotium rolfsii. Essa bactéria foi identificada através do sequenciamento de um fragmento do gene de 16S rRNA e por meio da análise de ácidos graxos (FAME). A obtenção dos metabólitos da bactéria selecionada foi realizada através da extração dos meios de cultura com os solventes hexano, acetato de etila e diclorometano. Após a concentração dos extratos, seus constituintes químicos foram realizados através de cromatografia em camada delgada, cromatografia em coluna, cromatografia gasosa acoplada ao espectrômetro de massas 
(CG-EM) e cromatografia líquida acoplada ao espectrômetro de massas (CL-EM). Os extratos obtidos por meio de diclorometano e acetato de etila continham diferentes componentes químicos que mostraram atividade inibitória contra os três fitopatógenos testados. O método cromatográfico CL-EM permitiu a identificação de uma substância antifúngica produzida pela bactéria endofítica, Bacillus pumilus, conhecida como pumilacidina. 


\title{
ANTIFUNGAL ACTIVITY OF SECONDARY METABOLITES PRODUCED BY Bacillus pumilus MAIIIM4a, AN ENDOPHYTIC FROM CASSAVA
}

\author{
Author: FLÁVIA MANDOLESI PEREIRA DE MELO \\ Adviser: Dra. MARLI DE FÁTIMA FIORE
}

\section{SUMMARY}

Endophytic microorganisms are defined as organisms that inhabit the interior of a vegetable at least during a period of the vital cycle, without causing any apparent damage. In the search for new organisms and new secondary metabolites, a study was conducted to evaluate the chemical diversity of endophytic bacteria through the isolation and identification of secondary metabolites produced by endophytic bacteria of cassava cultivated by Brazilian Amazon Indian tribes. Sixty seven endophytic bacteria isolated from cassava were screened using in vitro antagonisms tests. An endophytic bacterium, the Bacillus pumilus, which showed a strong inhibitory activity against Rhizoctonia solani, Pythium aphanidermatum and Sclerotium rolfsii was selected. This bacterium was identified by sequencing of 16S rRNA genes and by FAME. The bacterial endophytic localization was confirmed by cassava cell tissue examination using scanning electron microscopy. The bacterial metabolites were extracted from the culture media using the solvents hexan, ethyl acetate and dichloromethane. After concentrate the extracts their chemical constituents were analyzed using thin layer chromatography (TLC), chromatography column, gas chromatography coupled with mass spectrometry (GC/MS) and liquid chromatography coupled with mass spectrometry (LC/MS). The extracts obtained with dichloromethane and ethyl acetate contained different chemical 
xvii

compounds that showed inhibitory activity against the three plant-pathogenic fungi tested. The LC/MS method allowed the identification of an antifungal compound produced by the $B$. pumilus, which is known as pumilacidin. 


\section{INTRODUÇÃo}

A biodiversidade microbiana é muito pouco conhecida, mormente em habitats específicos, como o interior das plantas e em habitats extremos. Em geral, os dados são conservadores e subestimados. Mesmo sendo ainda muito pouco conhecida, a biodiversidade microbiana é responsável pela produção de centenas de substâncias farmacêuticas, como vacinas, enzimas, antibióticos, além de ser fonte de alimentos, representando dezenas de bilhões de dólares em todo o mundo. A versatilidade bioquímica e diversidade de endofíticos representam uma enorme variedade de genes que são ainda desconhecidos. Está se descobrindo cada vez mais funções gênicas, particularmente, para remediação ambiental e propósitos industriais. Assim, o uso de bactérias e fungos abre novas áreas de exploração biotecnológica, que dita a necessidade de isolar, caracterizar e determinar a biodiversidade microbiana em diferentes espécies de plantas.

Microrganismos endofíticos, geralmente fungos e bactérias, são aqueles que vivem sistematicamente no interior das plantas, sem causar aparentemente dano a seus hospedeiros. São distintos dos microrganismos epifíticos, que vivem na superfície dos órgãos e tecidos vegetais.

A mandioca (Manihot esculenta Crantz) é uma planta arbórea cuja origem e distribuição, acredita-se, ser o Brasil. O gênero apresenta cerca de 98 espécies e a característica mais utilizada na classificação popular de etnovariedades de mandioca é a diferença entre o sabor amargo ou doce, que muitas vezes está relacionado com a presença de ácido cianídrico em diferentes concentrações, o que confere toxicidade à cultura. 
As etnovariedades de mandioca representam uma forma de recurso genético que deve ser preservada e conservada, pois, poderá ser utilizada pelos melhoristas em programas de melhoramento genético no futuro. A mandioca é uma das principais espécies cultivadas por agricultores das regiões tropicais. Nesse contexto, o conhecimento das bactérias endofíticas dessa cultura, será importante para se resgatar possíveis perdas e inoculá-las em plantas não adaptadas, como também visando proteção contra pragas.

Bactérias endofíticas isoladas de etnovariedades de mandioca estão presentes em todas as espécies vegetais, permanecendo em estado de latência ou colonizando ativamente os tecidos de forma local ou sistêmica. Por ocuparem um nicho ecológico semelhante àqueles ocupados por patógenos, as bactérias endofíticas apresentam grande potencial para o controle biológico. Este controle pode ser resultante de diversos mecanismos: competição por espaço e nutrientes na planta hospedeira; produção de compostos antimicrobianos; indução de resistência sistêmica.

Apesar de devidamente comprovada a existência da microbiota endofítica, muitas pesquisas ainda necessitam ser feitas a respeito de aspectos ecológicos, genéticos e fisiológicos dessa interação. Antes disso, é interessante se conhecer a diversidade desses organismos, sua presença, freqüência e funções.

Há uma série de razões para que se aprofundem os estudos com endofíticos. Primeiro, a falta de informações para elucidar a base biológica dessas interações. Segundo, porque os endofíticos são vantajosos, pois muitos benefícios para a planta têm sido atribuídos, principalmente devido à capacidade destes de produzirem metabólitos secundários que têm várias aplicações como no biocontrole de fitopatógenos, promoção de crescimento de plantas, indução de resistência sistêmica, drogas de uso farmacêutico como os antibióticos e agentes anticancerígenos. 


\section{REVISÃO DE LITERATURA}

\subsection{Bactérias endofíticas}

Microrganismos endofíticos são todos aqueles que habitam, pelo menos durante um período de seu ciclo vital, o interior de um vegetal. A distinção entre microrganismos endofíticos, epifíticos (que vivem na superfície de plantas) e fitopatogênicos (responsáveis por moléstias em plantas) é de cunho puramente didático, havendo uma gradação entre eles e ficando, portanto, muito difícil de serem estabelecidos claros limites entre as três categorias. Também os fungos micorrízicos e as bactérias fixadoras de nitrogênio, que vivem em íntimo relacionamento com plantas hospedeiras, são microrganismos endofíticos (Azevedo, 1998b).

Com exceção das bactérias transmitidas pelas sementes, os organismos penetram no tecido da planta, primariamente, através da zona radicular, embora porções da parte aérea, como flores, caules, cotilédones, possam ser utilizados como ponto de entrada (Kobayashi \& Palumbo, 2000). Dentro da planta os endófitos podem permanecer próximo ao local de entrada ou disseminarem-se dentro das células, nos espaços intercelulares ou no sistema vascular (Bell et al., 1995).

Os colonistas internos, em potencial, encontram seus hospedeiros por quimiotaxia, eletrotaxia ou acidentalmente. Motilidade da bactéria rizosférica associativa benéfica tem sido descrita para várias bactérias, incluindo Azospirillum brasilense $e$ Pseudomonas fluorescens (You et al., 1995). Em geral, a entrada no tecido da planta pode ser via estômato, lenticelas, ferimentos, áreas de emergência de raízes laterais e germinação radicular (Huang, 1986). Extensiva colonização por bactérias endofíticas tem sido observada nos ferimentos que ocorrem naturalmente como resultado do crescimento da planta (Sprent \& de Faria, 1988) ou nas zonas de emergência das raízes secundárias (Jacobs et al.,1985). 
As preferências bacterianas para colonização de áreas específicas da planta parecem ser específicas das espécies ou estirpes. Em geral, as bactérias endofíticas colonizam os espaços intercelulares (Reinhold \& Hurek, 1988). Poucos são os relatos demonstrando a colonização intracelular (Mahaffee et al., 1997; Quadt-Hallmann \& Kloepper, 1996), embora ela tenha sido detectada em gramíneas (Hurek et al., 1994), trigo (Gantar et al., 1991), arroz (You \& Zhou, 1989), batata (Frommel et al., 1991), cana de açúcar (James et al., 1994) e algodão (Quadt-Hallmann et al., 1997).

As pesquisas com microrganismos endofíticos, embora tenham sido iniciadas no século XVIII, somente nos últimos 20 anos os seus efeitos benéficos sobre a planta e a sua diversidade genética começaram a ser entendidos e estudados. No início dos anos 80 Webber (1981) foi um dos primeiros pesquisadores a relatar a importância de microrganismos endofíticos na proteção de plantas contra doenças. Posteriormente, outros benefícios foram descobertos. À medida que microrganismos endofíticos, principalmente fungos e bactérias, foram sendo bem estudados, verificou-se que eles poderiam possuir outras propriedades importantes, tais como a de conferir maior resistência de seus hospedeiros a condições de estresse hídrico, alterar propriedades fisiológicas de plantas que os albergam, produzir hormônios vegetais e outros compostos, tais como enzimas e fármacos de interesse biotecnológico. Além do mais, o estudo de microrganismos tem despertado interesse acadêmico, pois novas espécies microbianas têm sido descobertas, principalmente quando hospedeiros tropicais são investigados (Azevedo et al., 2000). O estudo de microrganismos endofíticos também mostrou que estes podem produzir metabólitos secundários, tais como antibióticos, outras substâncias antimicrobianas e citostáticas.

\subsection{Diversidade de bactérias endofíticas}

O número de espécies de bactérias endofíticas isoladas de uma determinada planta está diretamente associado à parte do hospedeiro que é utilizada no isolamento. Em Trifolium pratense L. 31 espécies de 14 gêneros diferentes foram recuperadas de dentro da folhagem, raízes e nódulos. 
A população de endofíticos, que habita uma determinada espécie de planta, depende das condições de sanidade do hospedeiro. Reiter et al. (2002), demonstraram que as populações de endofíticos isolados de caule de batata são diferentes quando se considera plantas sadias ou infectadas com patógenos. Resultados similares foram obtidos com bactérias da rizosfera de árvores de abacate infectadas com Phytophthora cinnamomi (Yang et al., 2001). A maior diversidade de endófitos em plantas doentes sugere o envolvimento destes microrganismos na defesa da planta contra o patógeno. Em plantas de citros, cultivadas no estado de São Paulo e Minas Gerais, Araújo et al. (2002), isolaram as seguintes espécies: Bacillus pumilus, Curtobactrium flaccumfaciens, Enterobacter cloacae, Methylobacterium spp (incluindo M. extorquens, $M$. fujisawaense, M. mesophilicum, M. radiotolerans e M. zatmanii), Nocardia sp., Pantoea agglomerans e Xanthomonas campestris. Em plantas com sintomas da clorose variegada a maior freqüência de espécies isoladas pertencia ao gênero Methylobacterium, enquanto que $C$. flaccumfaciens foi mais freqüentemente isolada de plantas assintomáticas; tal fato sugere que este organismo exerce alguma função na resistência do citros àquela doença. P. agglomerans foi isolada de plantas de citros independentemente de serem sintomáticas ou não. Pantoea agglomerans, juntamente com a espécie bacteriana Sphingomonas sanguinis têm sido isoladas como endofíticos em batata doce no Japão (Adachi et al., 2002).

O gênero Bacillus é citado em alguns trabalhos como a principal bactéria endofítica que ocorre em determinadas plantas (Hallmann et al., 1997). As espécies de Bacillus mais freqüentemente citadas como endofíticas são: Bacillus cereus (Araújo et al., 2002, Araújo et al., 2001, Pleban et al., 1995), Bacillus subtilis (Bai et al., 2002, Araújo et al., 2001), Bacillus megaterium (Sturz et al., 1997, Elvira-Recuenco \& van Vuurde, 2000, Araújo et al., 2001), Bacillus insolitus (Sturz et al., 1997), Bacillus brevis (Sturz et al., 1997), Bacillus pumilus (Araújo et al., 2002, Araújo et al., 2001), e Bacillus lentus (Araújo et al., 2001); estas espécies de Bacillus têm sido encontradas em uma grande variedade de espécies de plantas, tais como: ervilha (Elvira-Recuenco \& van Vuurde, 2000), Zea mays L. (Lalande et al., 1989), Gossypium hirsutum L. (Misaghi \& Donndelinger, 1990). 


\subsection{Efeitos benéficos de bactérias endofíticas nas plantas}

Trabalhos conduzidos na primeira metade do século XIX consideravam as bactérias endofíticas como contaminantes resultantes de incompleta desinfestação superficial ou como patógenos latentes (Hollis, 1949). Pesquisas recentes, porém, demonstraram que as bactérias endofíticas podem aumentar o crescimento das plantas e reduzir os sintomas de doenças causadas por vários patógenos de plantas (Chen et al., 1995; Frommel et al., 1991; Pleban et al., 1995) Do mesmo modo a baixa tolerância de plantas axênicas a estresses são atribuídos, em parte, à ausência de microrganismos endofíticos (Xu et al., 1995).

As bactérias endofíticas têm uma multitude de aplicações que aumentam a produção agrícola; elas aumentam o crescimento do trigo por meio da produção de fitohormônios (Barbieri et al., 1986), aumentam a produção de arroz por meio do aumento da disponibilidade de minerais (Murty \& Ladha, 1988), aumentam a resistência de plantas de algodão às doenças (Chen et al., 1995), contribuem no manejo de pragas do milho (Fahey et al., 1988), fixam nitrogênio no arroz e trigo (Webster et al., 1997) e aumentam a formação de tubérculos de batata em condições de estresse de calor (Bensalim et al., 1998). Ambientalmente o uso de endofíticos específicos pode ser preferível ao uso de fertilizantes químicos e aos pesticidas, não somente devido ao menor custo e tempo, mas por contribuir com um sistema agrícola sustentável. Zinniel et al. (2002) sugeriram que as bactérias endofíticas poderão ser utilizadas, futuramente, como produtoras de enzimas degradativas, para controlar certas doenças de plantas ou decompor produtos úteis.

As bactérias endofíticas, dependendo de seu efeito sobre as plantas hospedeiras, podem ser classificadas em três categorias: promotoras do crescimento da planta, inibidoras do crescimento da plantas e neutras quanto ao crescimento da planta (Sturz et al., 2000). Estirpes bacterianas que têm efeitos benéficos na saúde das plantas são denominadas como bactérias associativas benéficas da planta, bactérias promotoras de crescimento da planta (PGPB) ou rizobactérias promotoras do crescimento da planta (PGPR). As PGPB podem promover o crescimento da planta diretamente ou indiretamente, via o biocontrole de doenças, produção de fitormônios ou aumento do “status” nutricional da planta. 
Vários gêneros de bactérias endofíticas têm sido isolados de tecidos de plantas leguminosas e estas incluem: Aerobacter, Aeromonas, Agrobacterium, Bacillus, Chryseimonas, Curtobacterium, Enterobacter, Erwinia, Flavimonas, Pseudomonas e Sphungomonas (Gagne et al., 1985; Sturz et al., 1997; Elvira-Recuenco \& van Vuurde, 2000; Oehrle et al., 2000). O número de espécies de bactérias não rizobianas encontradas nos nódulos das leguminosas são geralmente altas. Sturz et al., (1997) caracterizaram 15 espécies bacterianas nos nódulos de trevo vermelho e verificaram que a densidade populacional variava de $10^{4}$ bactérias viáveis por grama de nódulos frescos. Em geral, nos tecidos de plantas as populações bacterianas endofíticas variam de $10^{2}$ a $10^{4}$ bactérias viáveis por grama (Kobayashi \& Palumbo, 2000).

Bai et al., (2002) demonstraram que três bactérias isoladas da superfície desinfestada de nódulos de soja, quando inoculadas juntas com os rizóbios aumentaram a nodulação e o peso das plantas, quando comparado àquelas que somente receberam o rizóbio. Estas bactérias foram classificadas como espécies de Bacillus (Bacillus thuringiensis e Bacillus subtilis) e foram incapazes de formar nódulos ou aumentar o crescimento da soja quando inoculadas sozinhas. Estes isolados bacterianos formam endósporos e poderiam ser adaptáveis à formulação dos inoculantes comerciais para aplicação nas culturas a campo.

O efeito positivo da inoculação combinada de algumas bactérias endofíticas com Rhizobium spp pode ser atribuído a uma nodulação mais precoce, um aumento no número de nódulos ou a uma melhora geral no desenvolvimento das raízes. O endófito que aumenta a eficiência do processo simbiótico em uma leguminosa, não necessariamente o faz em outra leguminosa. Em feijão, por exemplo, aumento na nodulação foi observado quando Rhizobium spp foram co-inoculados com Bacillus polymixa (Pedersen et al., 1995) ou com Azospirillum brasilense (Burdman et al., 1996). Em plantas de soja o sinergismo entre Bacillus e Rhizobium na rizosfera promove o crescimento e desenvolvimento da planta (Halverson \& Handelsman, 1991). Camacho et al. (2001), porém, verificaram que, embora a estirpe Bacillus sp CECT 450 aumentasse a nodulação em feijão (Phaseolus vulgaris L.) quando co-inoculadas com Rhizobium tropici CIAT 899, elas reduziram a nodulação em soja quando co-inoculadas com 
Bradyrhizobium japonicum USDA 110. A estirpe de Bacillus sp CECT 450 não afeta o crescimento do feijoeiro quando inoculado sozinho, sugerindo que a sua ação na planta é mediada pelo Rhizobium (Camacho et al., 2001). Em grão de bico (Cicer arietinum L.) Goel et al. (2002) também demonstraram o efeito benéfico da co-inoculação das sementes no processo de fixação do dinitrogênio atmosférico. Neste caso o autor utilizou as estirpes MRS23 e CRP55b de Pseudomonas e o rizóbio Mesorhizobium sp; aos 100 dias após a semeadura havia 100\% mais nódulos no grão de bico co-inoculado, do que nas plantas que receberam apenas o rizóbio.

Em nódulos de raízes de trevo foram isoladas 12 espécies de bactérias além do rizóbio, das quais oito foram específicas para este tecido (Sturz et al., 1997). Usando meio não seletivo, os autores constataram que $R$. leguminosarum bv trifolii constituiu somente 8,8 \% das bactérias recuperadas nos nódulos. A nodulação nas raízes do trevo foi aumentada quando $R$. leguminosarum bv trifolii foi co-inoculada com Bacillus insolitus, B. brevis ou Agrobacterium rhizogenes, Bacillus megaterium, Bordetella avium e Curtobacterium luteum promoveram o crescimento do trevo vermelho individualmente ou em combinação com $R$ leguminosarum bv trifolii.

Um grande número de bactérias endofíticas fixadoras de $\mathrm{N}_{2}$ tem também sido isoladas de culturas não-leguminosas. Baldani et al. (1986) isolaram Herbaspirillum seropedicae de raízes e caules de milho, arroz e sorgo esterilizados superficialmente. Cavalcante e Döbereiner (1988) e Gillis et al. (1990) isolaram uma bactéria diazotrófica tolerante a ácido, a Acetobacter diazotrophicus, associada com cana de açucar. Acetobacter diazotrophicus foi isolado de plantas de café (Jimenez-Salgado et al., 1997) e Herbaspirillum seropedicae e outros Herbaspirillum sp de plantas de banana e abacaxi (Weber et al., 2000). A bactéria diazotrófica Klebsiella oxytoca foi isolada de caule de batata doce cultivada no Japão (Adachi et al., 2002). Espécies deste gênero já foram anteriormente isoladas de diferentes culturas (McInroy \& Kloepper, 1991).

Bactérias do gênero Methylobacterium podem estar relacionadas à fixação biológica do nitrogênio em culturas não-leguminosas. Embora tenha sido demonstrada a existência de um isolado deste gênero que nodula e fixa nitrogênio em simbiose com legumes (Sy et al., 2001), outras Methylobacterium spp. foram isoladas de plantas como algodão, 
milho doce (McInroy \& Kloepper, 1991) e cultivares selvagens e tradicionais de arroz (Elbeltagy et al., 2001).

\subsection{Controle biológico de fungos fitopatogênicos por bactérias endofíticas}

Controle biológico é um processo natural de regulação populacional através de inimigos naturais. A utilização de inimigos naturais para o controle de populações de pragas propiciou o surgimento do controle biológico aplicado como uma biotecnologia baseada na utilização de recursos genéticos microbianos, insetos predadores e parasitóides, assim como os semioquímicos, substâncias utilizadas na comunicação intra e inter-específica (planta-inseto, inseto-inseto). A utilização de agentes de controle biológico e semioquímicos se insere no agronegócio através do controle natural de pragas e doenças de plantas, em substituição ou complementação aos pesticidas químicos no manejo integrado de pragas. Seu uso aumenta a qualidade do produto agrícola e reduz a poluição do meio ambiente contribuindo para a preservação dos recursos naturais e aumentando a sustentabilidade dos agroecossistemas.

Bactérias endofíticas estão presentes em todas as espécies vegetais, permanecendo em estado de latência ou colonizando ativamente os tecidos de forma local ou sistêmica. Por ocuparem um nicho ecológico semelhante àqueles ocupados por patógenos as bactérias endofíticas apresentam grande potencial para o controle biológico (Hallmann et al., 1997). Este controle pode ser resultante de diversos mecanismos: competição por espaço e nutrientes na planta hospedeira; produção de compostos antimicrobianos (Pleban et al., 1997); indução de resistência sistêmica (M'piga et al., 1997; Benhamou et al., 1996; Duijff et al., 1997).

Dentre os gêneros mais estudados como agentes de controle biológico estão Bacillus e Pseudomonas. Entretanto, um grande número de bactérias apresenta antagonismo contra vários tipos de fungos e bactérias patogênicas. Em batata (Solanum tuberosum) e trevo vermelho (Trifolium pratense) foram isoladas 25 espécies de bactérias endofíticas, de 18 gêneros, das quais 74\% apresentaram in vitro antibiose ao fungo patogênico Rhizoctonia solani (Sturz et al., 1998). Em arroz, foram isoladas bactérias endofíticas 
que apresentaram forte atividade antifúngica contra R. solani, Pythium myriotylum, Guamannomyces graminis e Heterobasidium annosum (Mukhopadhyay et al., 1996).

Com o auxílio da engenharia genética, novas formas de controle biológico vêm sendo desenvolvidas a partir de bactérias endofíticas. A introdução de genes exógenos nestas bactérias possibilita a aquisição de novas características utilizadas no controle de doenças e pragas. A bactéria Clavibacter xyli subsp. cynodontis é um endófito capaz de colonizar o xilema de várias espécies vegetais. Esta bactéria foi modificada para expressar o gene cryA(c), de Bacillus thuringiensis, que codifica uma proteína com atividade inseticida contra a broca do colmo de milho Ostrinia nubilalis (Fahey et al., 1988; Lampel et al., 1994). O gene cryA(c) foi inserido num vetor suicida que não se replica em Clavibacter xyli subsp. cynodontis. Um fragmento genômico de Clavibacter xyli subsp. cynodontis foi utilizado na construção para induzir recombinação do vetor com o cromossomo da bactéria. Os transformantes resultantes apresentaram grande estabilidade do gene inserido no cromossomo bacteriano.Uma alternativa na construção de vetores de expressão estáveis e que se mantenham em maior número de cópias nos transformantes seria a utilização de plasmídios nativos, obtidos das próprias bactérias endofíticas (Uratani et al., 1992).

\subsubsection{Bactérias para o Controle de Pragas na Agricultura}

À primeira vista as plantações modernas (monoculturas) são como verdadeiros paraísos para insetos, habitats ideais para a reprodução e alimentação de um amplo espectro de espécies. Todavia, muitos fatores adversos para os insetos também se fazem presentes, como clima não propício, o longo tempo de geração de algumas espécies, além de um grande número de espécies de inimigos naturais. Entre estes inimigos estão as doenças causadas por microrganismos patogênicos (Burges \& Pillai, 1987).

Com tantos problemas em potencial para os insetos, estes deveriam estar sempre naturalmente sob controle, sem se tornarem pragas. Todavia, estes inimigos naturais e doenças muitas vezes se abatem sobre os insetos tarde demais para que sejam evitados danos econômicos ou até a morte das plantas atacadas (Burges \& Pillai, 1987). 
Nestes últimos 20 a 25 anos o homem vem estudando os processos naturais de doenças de insetos, isolando e selecionando cepas eficientes dos microrganismos responsáveis, desenvolvendo sistemas de produção e formulação de inóculos e testandoos no campo. Este processo teve como resultado o desenvolvimento da tecnologia dos bioinseticidas microbianos, com alguns sucessos comerciais e aceitação entre os produtores. O controle biológico de pragas no Brasil tem um grande caminho a ser trilhado, com a biodiversidade tropical encerrando um grande número de espécies ainda desconhecidas, adaptadas às nossas condições ambientais, com potencial para uso tecnológico no controle das pragas encontradas nas culturas brasileiras.

Dentre as bactérias esporulantes, merecem especial destaque às espécies do gênero Bacillus, que se caracterizam pela produção de toxinas e enzimas, causando doenças nos insetos infectados. A espécie mais estudada e utilizada no campo é B. thuringiensis, que apresenta patogenicidade seletiva, de acordo com a estirpe em questão (Vankova, 1979). Esta é uma espécie bastante heterogênea. As características bioquímicas e serológicas estão relacionadas à especificidade e virulência das estirpes, realçando a necessidade de maior aprofundamento nos estudos taxonômicos dos membros desta espécie. Outra característica importante é sua ampla distribuição, sendo encontrada tanto em ambientes de clima tropical assim como nas zonas temperadas, o que a classifica como espécie cosmopolita (Krywienczyk \& Fast, 1978). O primeiro registro de produção comercial de B. thuringiensis data de 1938, para o controle de lagartas. Atualmente no Brasil são encontrados três produtos a base de B. thuringiensis: Dipel, Thuricide e Bactospeine (Habib \& Andrade, 1984).

As principais variedades de $B$. thuringiensis são: $B$. thuringiensis var. kurstaki, $B$. thuringiensis var. tenebrionis e $B$. thuringiensis var. israelensis que causam doenças em lagartas, coleópteros e dipteras, respectivamente (Habib \& Andrade, 1984). A toxina produzida por $B$. thuringiensis mais relevante para sua efetividade no controle de pragas é chamada de d-endotoxina. Este é o componente principal dos produtos comerciais à base de $B$. thuringiensis e é sintetizado durante o processo de esporulação e formação do cristal protéico. Ele não tem ação tóxica e sua dissolução no elevado pH do trato gastrointestinal dos insetos é que causa a liberação da d-endotoxina. A toxicidade desta 
toxina depende do hospedeiro e é passível de adapatação co-evolutiva, propiciando a ocupação de novos nichos ecológicos (Burges, 1981).

Outra espécie de Bacillus com algum potencial para o controle de insetos é $B$. cereus, que também tem ampla distribuição geográfica e é um saprófita de solos. Causa doenças em insetos com líquido intestinal na faixa neutra de $\mathrm{pH}(6,6$ - 7,4), como himenópteros desfolhadores de essências florestais, o que a difere de B. thuringiensis, cujas toxinas agem em níveis de pH elevados (Habib \& Andrade, 1984).

Bacillus popilliae e $B$. lentimorbus são espécies que provocam a chamada doença leitosa tipo A e B em larvas de besouros da ordem Scarabaeidae, sendo utilizadas para o controle do escaravelho japonês Popillia japonica. São patógenos obrigatórios com a vantagem de ter esporos resistentes a altas temperaturas, baixos teores de umidade e radiação ultravioleta, além de apresentar alta longevidade nos corpos de larvas mortas e no solo. No Brasil têm potencial para o controle de escarabeídeos de toletes de cana (Eutheola humilis, Stenocrates spp. e Migdolus morretesi) (Habib \& Andrade, 1984).

Dentre as bactérias não esporulantes encontra-se a Serratia marcescens que ocorre em larvas e pupas de Anthonomus grandis (bicudo do algodoeiro) (Andrade et al., 1994). Apresenta o inconveniente de também ser potencialmente um patógeno ao homem. Há relatos de casos de septicemia e infecções generalizadas causadas por S. marcescens. Dentre as Pseudomonas tem-se três espécies, patógenas potenciais de insetos: $P$. fluorescens, P. chlororaphis e P. aureofaciens. Tal qual o exemplo anterior, a dificuldade de adoção destas espécies se dá pelo fato de que entre elas ocorrem estirpes que são também patógenas a plantas e vertebrados (Andrade et al., 1994).

\subsection{Gênero Bacillus como endófito de mandioca}

O gênero Bacillus é caracterizado como bactéria Gram-positiva, aeróbia ou anaeróbia facultativa, formato circular, formação de esporos e, contêm mais de 60 espécies as quais apresentam diferenças fenotípicas (Claus \& Berkeley, 1986). Espécies de Bacillus tem características especiais que fazem deles candidatos em potencial como agentes de controle biológico. Primeiramente, eles são bem conhecidos como produtores de antibióticos com atividade antagônica contra fungos e bactérias patogênicas (Loeffler 
et al., 1986; Krebs et al., 1998). Segundo, eles formam esporos que podem ser facilmente formulados, e tem alta viabilidade comparada com células vegetativas (Bochow et al., 1995). Terceiro, eles são comumente encontrados no solo (Stabb et al., 1994). A atividade antagônica tem sido freqüentemente associada com produção de metabólitos secundários e com propriedades antibióticas (Silo-Suh et al., 1994; Stabb et al., 1994; Asaka \& Shoda, 1996).

A maioria dos antibióticos produzida por Bacillus spp. tem sido caracterizada como dipeptídeos ou peptídeos cíclicos com baixo peso molecular (Loeffler et al., 1986; Nakano \& Zuber, 1990). De acordo com Silo-Suh et al. (1994), os metabólitos produzidos por Bacillus spp. podem afetar a microflora na rizosfera. Tão importante quanto à produção de antibióticos, a habilidade de colonizar endofiticamente tem sido considerada um fator relevante no papel dos microrganismos como agentes de controle biológico contra patógenos vasculares (Kloepper et al., 1999).

\subsection{Cultura da mandioca}

A mandioca é uma planta dicotiledônea da família Euphorbiaceae e gênero Manihot. Este gênero compreende várias espécies, das quais destacam, do ponto de vista econômico, a $M$. utilissima Pohl (sinonímia da espécie $M$. esculenta Crantz) e a $M$. dulcis Pax. A principal diferença botânica existente entre estas duas espécies parece residir no fruto que, na primeira, é alado e na segunda, é liso. As variedades cultivadas no Estado de São Paulo pertencem à espécie $M$. utilíssima que tanto podem se apresentar na forma doce como na amarga. A mandioca é uma planta de origem brasileira. Os índios já a cultivavam, por ocasião do descobrimento do Brasil. Hoje em dia, é explorada em todo o território brasileiro, em todos os países sul e centro-americanos e nas Antilhas. Em outras regiões do mundo de clima tropical e subtropical a mandioca é também cultivada, principalmente em Java, nas Filipinas, no Ceilão, na Tailândia, em grande parte da África e em Madagascar. A importância econômica da cultura está na produção de raízes tuberosas e feculentas, que são utilizadas na alimentação de humanos e animais, na fabricação de produtos alimentícios diversos e na produção de álcool (EMBRAPA MANDIOCA E FRUTICULTURA, 2004). 
As variedades de mandioca chamadas "bravas" podem provocar intoxicações quando ingeridas cruas ou mesmo cozidas devida à presença da substância "linamarina" (glicosídeo cianogenético) capaz de produzir o ácido cianídrico (HCN), quando na presença dos ácidos ou enzimas encontradas no estômago. As variedades relatadas como "mansas" (aipim ou macaxeira) também possuem essa substância, porém, em quantidades inócuas. A secagem pelo calor do sol ou por secadores elimina a “linamarina” por volatilização. Por outro lado, a cocção pode não eliminá-la totalmente, razão pela qual a mandioca "brava", ainda que cozida, pode ocasionar problemas (EMBRAPA MANDIOCA E FRUTICULTURA, 2004).

A presença dessa substância tóxica é constatada em todas as partes do vegetal. Nas folhas são encontradas as maiores porcentagens, as raízes possuem teores mais elevados do que a polpa. A variação do teor em HCN nas plantas de mandioca, não está associada somente às variedades das plantas, mas também, à idade (as mais novas, em geral, são mais ricas), como também está sujeita a influencia do meio ambiente, como solo, clima e altitude. Existem relatos de variedades que, sendo venenosas em uma localidade, passam a ser "mansas" quando plantadas em outros lugares, e vice-versa.

Resultados obtidos sob as mais variadas condições mostram que a cultura da mandioca acumula de 1,93 a 10,96 kg de nitrogênio, de 0,56 a 1,89kg de fósforo e de 4, 69 a 9, 04 kg de potássio / tonelada de raízes de tubérculos (Howeler, 1981). Apesar da alta exigência nutricional, principalmente em nitrogênio e potássio, e, portanto, ser considerada uma cultura que esgota os solos, a mandioca é tradicionalmente cultivada sem a aplicação de fertilizantes (Howeler, 1981) e não responde de maneira consistente, à adição de nitrogênio, mesmo em solos com baixa disponibilidade de nutrientes, como salientada por Gomes (1988).

\subsection{Metabólitos antifúngicos produzidos por Bacillus}

Os antibióticos são metabólitos secundários que se acumulam no meio de cultura no fim da fase de crescimento exponencial (quando da fase estacionária). Estes produtos não são essenciais para o crescimento e reprodução dos microrganismos que os produzem, nem aparentemente lhes confere nenhuma vantagem evolutiva. No entanto, 
em termos competitivos, os microrganismos produtores de antibióticos são favorecidos em relação aos não produtores. Esses tipos de substâncias químicas matam ou inibem o crescimento de outras espécies microbianas, mesmo em pequenas quantidades. Nesse sentido, os antibióticos têm sido utilizados com fins terapêuticos no tratamento de doenças infecciosas.

Antibióticos antifúngicos têm função de controlar biologicamente patógenos de plantas (Mckeen et al., 1986; Fravel, 1985; Phae et al., 1990; Potera, 1994; Leifert et al., 1995) e fungos pós-colheita (Klish et al., 1993). Várias dessas substâncias antifúngicas têm sido caracterizadas e muitas são polipeptídeos compostos em sua maioria por aminoácidos e alguns outros resíduos. Como exemplo tem-se a fungicina M-4 produzida pelo Bacillus licheniformis, a qual é composta por 34 resíduos de aminoácidos de sete tipos (Lebbadi et al., 1994) e a Rhizoctina A produzida pelo Bacillus subtilis ATCC6633 que é um phosphono-oligopeptídeo (Kluger et al., 1993).

\subsection{Métodos cromatográficos para identificações de substâncias bioativas}

De modo geral, as técnicas cromatográficas são de larga aplicação em química e bioquímica, na pesquisa e na indústria. Segundo Collins \& Bonato (1990) estas técnicas cromatográficas variam desde as de extrema simplicidade, que podem ser facilmente manipuladas por não-peritos, até as de alta sofisticação, usadas somente por especialistas. Entre estes dois extremos existem muitas variações de maior ou menor complexidade.

Os termos “cromatografia”, “cromatograma” e “método cromatográfico” são atribuídos ao botânico Mikhael Semenovich Tswett, que em 1906, utilizou-os em dois trabalhos descrevendo suas experiências na separação dos componentes de extratos de folhas e gema de ovo, onde usou colunas de vidro recheadas com vários sólidos, finalmente divididos, e arrastou os componentes com éter de petróleo. O nome deriva-se das palavras gregas “chrom” (cor) e "graphe” (escrever), embora o processo não dependa da cor, exceto para facilitar a visualização dos componentes separados.

Entre os métodos modernos de análise, a cromatografia ocupa um lugar de destaque devido a sua facilidade em efetuar a separação, identificação e quantificação das 
espécies químicas, por si mesma ou em conjunto com outras técnicas instrumentais de análise, como, por exemplo, a espectrofotometria ou a espectrometria de massas (Collins \& Bonato 1990).

A cromatografia é um método físico-químico de separação de componentes de uma mistura, realizada através da distribuição destes componentes entre duas fases, que estão em contato íntimo. Uma das fases permanece estacionária enquanto a outra se move através dela. Durante a passagem da fase móvel sobre a fase estacionária, os componentes da mistura são distribuídos entre as duas fases, de tal forma que cada um dos componentes é seletivamente retido pela fase estacionária, resultando em migrações diferenciais destes componentes (Collins \& Bonato, 1990).

Entretanto, considera-se que a classificação mais importante em cromatografia baseia-se no mecanismo de separação, que pode ser por processos físicos, químicos ou mecânicos. Os processos físicos são de sorção-adsorção (partição) e são baseados principalmente em atrações eletrostáticas ou dipolares (forças de van der Walls), incluindo a formação de pontes de hidrogênio.

Quando se trata de um sólido, como sílica ou alumina, como fase estacionária, a adsorção do soluto ocorre na interfase entre o sólido e a fase móvel, devido à presença de grupos ativos nas suas superfícies. A dessoração do soluto implica na volta deste a fase móvel. Este é o mecanismo mais comumente encontrado em cromatografia em camada delgada (CCD), em cromatografia gás-sólido (CGS), cromatografia líquidosólido (CLS) e cromatografia supercrítica com fase estacionária sólida (CSS).

\subsubsection{Cromatografia por adsorção}

Empiricamente considera-se a cromatografia quando se usa uma coluna recheada com um sólido (fase estacionária) e uma fase móvel líquida, onde a sorção isotérmica (adsorção) refere-se a um aumento da concentração do material (que está excesso na fase móvel) entre as superfícies das fases móvel e estacionária. Esta cromatografia em coluna (adsorção) pode ser primeiramente escolhida porque é tecnicamente mais simples não exigindo instrumentação esmerada. Dependendo do tamanho da coluna usada, é facilmente aplicada para fins preparativos, devendo ser monitorada, principalmente, por 
cromatografia em camada delgada. A fase móvel, quando está passando através do adsorvente na coluna, arrasta consigo os componentes da amostra que está sendo cromatografada. A velocidade de movimento descendente de um componente depende de sua adsorção pela fase estacionária, isto é, quanto mais fracamente o componente for adsorvido mais rápido é sua passagem pela coluna, e vice versa. Conclui-se, portanto, que quanto maior a diferença entre os coeficientes de adsorção, mais completa será a separação do composto (terá maior grau de pureza). Esta separação dos componentes de uma mistura é devido às diferenças nas forças de adsorção (forças eletrostáticas de van der waals) entre eles e o adsorvente (Collins \& Bonato, 1990).

\subsubsection{Cromatografia em Camada Delgada (CCD)}

Cromatografia em camada delgada (CCD) consiste na separação dos componentes de uma mistura através da migração diferencial sobre uma camada delgada de adsorvente retido sobre uma superfície plana. Esta técnica teve início com os trabalhos de Izmailov e Shraiber em 1938, sendo que somente a partir da década de 60 passou a ser largamente utilizada, de tal forma que hoje é praticamente indispensável em qualquer laboratório que envolva análise de substâncias orgânicas e organometálicas.

O grande desenvolvimento desta técnica é conseqüência natural das múltiplas vantagens que ela oferece, tais como: fácil compreensão e execução, separações em breve espaço tempo, versatilidade, grande reprodutibilidade e baixo custo. Pode ser de aplicação analítica ou preparativa, cuja escala está na dependência da espessura da camada de adsorvente e da amostra em análise (Collins \& Bonato, 1990).

O processo de separação está fundamentado, principalmente, no fenômeno da adsorção. Entretanto, usando fases estacionárias tratadas pode ocorrer também por partição ou troca iônica, o que permite seu emprego tanto na separação de substâncias hidrofóbicas como hidrofílicas. A CCD é a mais simples e a mais econômica das técnicas cromatográficas quando se pretende separação rápida e identificação visual. Ela tem demonstrado ser de valor extraordinário na análise de substâncias orgânicas e inorgânicas, acompanhamento de reações em sínteses e de processos de purificações. Seria muito difícil relacionar todas as aplicações da CCD; mais fácil seria citar que ela 
está presente em quase todos os laboratórios de química ou biologia, em face de fatos como a existência de diferentes fases móveis e estacionárias, diferentes técnicas de desenvolvimento e visualização, a sua rápida execução, a sua reprodutibilidade e ao seu custo não elevado (Collins \& Bonato, 1990).

\subsubsection{Cromatografia Gasosa Acoplada ao Espectrômetro de Massas}

Gases ou substâncias volatilizáveis podem ser separados, utilizando a técnica denominada “Cromatografia Gasosa”. A separação baseia-se na diferente distribuição da amostra entre uma fase estacionária (sólida ou líquida) e uma fase móvel (gasosa).

A cromatografia gasosa é uma técnica com um poder de resolução excelente, tornando possível, muitas vezes, análise de dezenas de substâncias presentes em uma mesma amostra. Um dos principais motivos que tornam a cromatografia gasosa de uso bastante acentuado é a sua sensibilidade. Dependendo do tipo de substância analisada e do detector empregado, consegue-se detectar cerca de $10^{-12} \mathrm{~g}$. Essa sensibilidade faz com que haja necessidade de apenas pequenas quantidades de amostra, o que em certos casos, é um fator crítico e limita a utilização de outras técnicas. É importante salientar ainda que a cromatografia gasosa é excelente como técnica quantitativa, sendo possível a obtenção de resultados quantitativos em concentrações que variam de picogramas a miligramas. A espectrometria de massas (EM) utiliza o movimento de íons em campos elétricos e magnéticos para classificá-los de acordo com sua relação massa-carga. Desta maneira, a espectrometria de massas é uma técnica analítica por meio da qual as substâncias químicas são identificadas, através da separação de íons gasosos de acordo com o campo elétrico e magnético. O instrumento que realiza essa operação é conhecido como espectrômetro de massas. A EM oferece informação qualitativa e quantitativa sobre a composição atômica e molecular de materiais inorgânicos e orgânicos. (Collins \& Bonato, 1990).

A cromatografia gasosa associada à espectrometria de massas (CG/EM) tem sido considerada uma técnica analítica adequada para a análise de misturas complexas. Tem, no entanto, a grande limitação de ser aplicável apenas a moléculas relativamente voláteis e termicamente estáveis. 


\subsubsection{Cromatografia líquida acoplada ao espectrômetro de massas (CL/EM)}

A cromatografia líquida nasceu essencialmente como uma técnica de separação, mas com os recursos que ela apresenta atualmente, passou a ocupar um lugar de grande destaque como técnica analítica qualitativa e quantitativa (Collins \& Bonato, 1990).

Atualmente é grande o número de problemas relacionados com a contaminação ambiental e a CLAE (Cromatografia Líquida de Alta Eficiência) é muito utilizada na solução destes problemas. Alguns pesticidas são facilmente determinados através da CLAE.

O acoplamento da cromatografia líquida com espectrometria de massas tem sido estudado há cerca de 25 anos e as vantagens iniciais que incentivaram o desenvolvimento desta técnica multidimensional são: detector universal para CL; potencial para análises de compostos não voláteis; potencial para análise de compostos termolábeis; evita a necessidade de derivação do analito; baixos limites de detecção; identificação não ambígua dos analitos e avaliação de pureza dos picos. Entretanto a história da CL/EM tem sido caracterizada pelas muitas tentativas em resolver as incompatibilidades fundamentais geradas entre estas duas técnicas (Collins \& Bonato, 1990).

O primeiro problema é a quantidade do efluente da coluna que pode ser introduzida no sistema de vácuo do EM. Normalmente a CLAE emprega colunas analíticas (cerca de 4,6 mm diâmetro) e vazões típicas de $1 \mathrm{ml} \mathrm{min}^{-1}$.

O segundo problema é a composição do efluente da coluna. A interface CL/EM impõe restrições quanto à composição da fase móvel, tais como tampão fosfato, EDTA, reagente par-iônico como tetraalquilamônio e alquilsulfonatos, são proibidos.

O terceiro problema é o tipo de analito a ser utilizado. Para obter sucesso no acoplamento de CL/EM é necessário o desenvolvimento de técnicas de ionização capazes de ionizar compostos altamente polares, termolábeis, iônicos e/ou compostos de massa molar alta (Collins \& Bonato, 1990).

A cromatografia gasosa associada à espectrometria de massa (CG/EM) tem sido considerada uma técnica analítica adequada para a análise de misturas complexas. Tem, no entanto, a grande limitação de ser aplicável apenas a moléculas relativamente voláteis 
e termicamente estáveis. Um acoplamento semelhante entre a cromatografia líquida e a espectrometria de massa (CL/EM) é de todo o interesse, para a análise de compostos sem aquelas características, para os quais a análise por CG/EM só podia ser utilizada recorrendo a derivatizações que tornam o processo analítico muito demorado. Uma das maiores dificuldades nesta combinação tem sido a diferença fundamental entre as condições de operação, sendo de salientando, entre elas, os fluxos de líquido do CL incompatíveis com o sistema de vácuo do EM da ordem de $10^{-3}$ a $10^{-6} \mathrm{~Pa}$. Várias interfaces têm sido desenvolvidas sendo que a interface à pressão atmosférica (API) quando operada no modo "electrospray” é única no seu grande potencial para a análise de uma variedade de moléculas com uma vasta gama de massas moleculares, com uma sensibilidade da ordem dos fentomole. A ionização por “electrospray” requer um fornecimento constante de líquido e é por isso facilmente acoplada a um sistema de separação, tal como um cromatógrafo líquido. Uma fonte de “electrospray” funciona, portanto, como interface para CL/EM (Collins \& Bonato, 1990).

Com o desenvolvimento a nível instrumental, CL/EM tornou-se uma técnica que pode ser aplicada num grande número de áreas, como, por exemplo, ambiente e bioanálise.

O maior sucesso da técnica tem sido na sua aplicação na análise de moléculas biológicas não voláteis. Entre estas se encontram os peptideos e proteínas que podem ser protonados principalmente nas zonas básicas, ou seja, nos grupos amino terminais.

Os oligonucleotideos podem ser carregados no modo iônico negativo, neste caso o grupo fosfato fornece a carga por abstracção do próton. Moléculas neutras, tais como oligossacarídeos, podem também ser detectadas porque se ligam a íons $\mathrm{Na}^{+}$ou outros metais alcalinos como agente de carregamento. 


\section{OBJETIVO PRINCIPAL}

- Isolar bactérias endofíticas da cultura de mandioca e caracterizar os metabólitos secundários produzidos por aquela que apresentar maior atividade biológica contra fungos fitopatogênicos, tais como Rhizoctonia solani, Pythium aphanidermatum e Sclerotium rolfsii causadores de podridões radiculares.

\section{Objetivos Específicos:}

- Coletar plantas inteiras de mandioca provenientes do estado da Amazônia para isolamento de bactérias endofíticas;

- Realizar testes de antagonismo in vitro dos isolados, para avaliação do halo de inibição do micélio;

- Identificar por duas técnicas (FAME e $16 \mathrm{~S}$ rDNA) a bactéria endofítica selecionada dentre os isolados;

- Análise de biomassa total da bactéria selecionada em diferentes meios de cultura;

- Obter extratos orgânicos do isolado selecionado com diferentes solventes;

- Teste de antibiose frente aos fitopatógenos, Rhizoctonia solani, Pythium aphanidermatum e Sclerotium rolfsii causadores de podridões radiculares;

- Análise dos extratos orgânicos do isolado selecionado por diferentes métodos cromatográficos;

- Observar por microscopia eletrônica de varredura a colonização e o endofitismo do isolado selecionado em diferentes partes da planta de mandioca. 


\section{MATERIAL E MÉTODOS}

\section{1 Área de coleta}

Foram coletadas plantas inteiras de mandioca mantidas por pequenos agricultores e tribos indígenas no estado do Amazonas, na região de Autazes (Fig.1). As plantas foram mantidas a baixa temperatura e transportadas para o laboratório de Microbiologia Ambiental da Embrapa Meio Ambiente onde procedeu-se ao isolamento dos microrganismos endofíticos. Em cada local amostrado, foram retiradas de três a seis plantas.
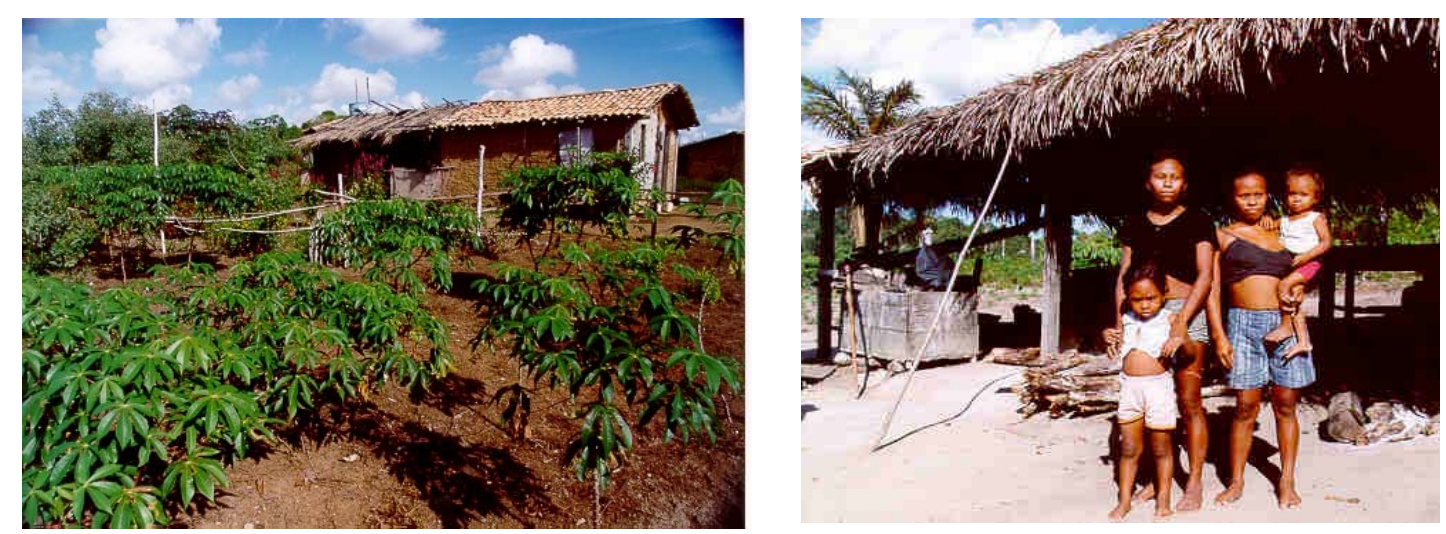

Figura 1 - Casa de farinha dos índios Ticunas na Aldeia Patauá, próximo ao Rio Manacapuru na Amazônia, onde foram feitas coletas de etnovariedades de mandioca.

Fotos: I.S Melo

\subsection{Isolamento das bactérias endofíticas da mandioca}

O material botânico coletado foi processado após a coleta, tendo sido lavado abundantemente com água corrente e detergente neutro para retirar o excesso de microrganismos epifíticos. Em seguida, em câmara asséptica, o material foi imerso em álcool 70\% por $1 \mathrm{~min}$, em hipoclorito $2 \%$ por 6 min e novamente em álcool $70 \%$ por 30 s, para retirar o excesso de hipoclorito. Lavou-se, então, em água destilada esterilizada 
da qual retirou- se $50 \mu \mathrm{L}$ para fazer o controle da assepsia (Pereira, 1993). Após a assepsia, pequenos fragmentos medindo aproximadamente $8 \mathrm{X} 8 \mathrm{~cm}$ foram plaqueados em meio de cultura Tryptona Soya Agar (TSA) e amido caseína. Ambos os meios de cultura foram suplementados com $1000 \mu \mathrm{L} \mathrm{mL}^{-1}$ do fungicida benomyl, para inibir o crescimento de fungos.

Para cada parte da planta (raiz, manivas e folhas) e, para cada planta, foram feitas três placas de cada meio de cultura, cada uma com sete pedaços do tecido vegetal. As culturas foram incubadas em sala com temperatura ambiente entre $25^{\circ} \mathrm{C}$ e $27^{\circ} \mathrm{C}$ e luz constante.

A avaliação do crescimento bacteriano foi feita a cada dois dias, por um período de 10 dias. As bactérias endofíticas foram retiradas da "placa-mãe” e transferidas para outras placas com o mesmo meio de cultura. Colônias individuais foram purificadas pelo método do esgotamento por estrias cruzadas e então, conservadas em óleo mineral e armazenadas a $4^{\circ} \mathrm{C}$. As freqüências dos endófitos foram calculadas através do número de colônias obtidas dividido pelo número de fragmentos incubados.

\subsection{Teste de antagonismo}

Sessenta e sete isolados bacterianos foram submetidas a uma seleção através de testes de antagonismo in vitro. Estas bactérias foram crescidas em meio de cultura sólido BDA (Batata-Dextrose-Ágar). Após o crescimento da bactéria em placas previamente esterilizadas, o fitopatógeno Pythium foi inoculado na outra extremidade da placa para avaliação do halo de inibição do micélio. Após esse "screening”, as bactérias que apresentaram maior inibição contra o patógeno, foram utilizadas na avaliação de seus metabólitos secundários.

\subsection{Triagem das melhores linhagens com ação antagonista}

Da avaliação acima foi selecionada uma bactéria endofítica com forte atividade antagônica frente ao Pythium. A linhagem selecionada, identificada como Bacillus pumilus, foi submetida ao teste de antagonismo frente a mais dois fitopatógenos, Rhizoctonia solani e Sclerotium rolfsii. 


\subsection{Identificação da bactéria endofítica utilizando o gene 16S rDNA}

Os isolados foram cultivados em $10 \mathrm{~mL}$ de meio de cultura TSA líquido e incubados por 48 horas a $28^{\circ} \mathrm{C}$, em agitador a $120 \mathrm{rpm}$. Após esse período, a suspensão bacteriana foi recolhida em tubos de $15 \mathrm{~mL}$ e centrifugada por 15 minutos a $7.000 \mathrm{~g}$; o sobrenadante foi descartado. O precipitado foi ressuspendido em $500 \mu \mathrm{L}$ de TE (TrisHCl 1 M pH 7,5, 10 mL; EDTA 0,5 M pH 8,0, 2 mL; água destilada, $1000 \mathrm{~mL}$ ) e centrifugado 13.000 g; O sobrenadante foi novamente descartado e o precipitado ressuspendido em $500 \mu \mathrm{L}$ de TE, onde foram adicionados $30 \mu \mathrm{L}$ de SDS 10\% e 0,5 g de sílica. O material foi agitado em "bead beating” (Biospec products) por $30 \mathrm{~s}$, para lise do envoltório celular. O DNA foi extraído com fenol/clorofórmio 1:1 e precipitado com isopropanol e $\mathrm{NaCl}(5 \mathrm{M})$. Em seguida procedeu-se a lavagem do DNA com etanol 70\% e o secamento a $37^{\circ} \mathrm{C}$. Após a ressuspensão do DNA seco em $50 \mu \mathrm{L}$ de água ultrapura esterilizada (Milli-Q), ele foi estocado a $-20^{\circ} \mathrm{C}$. Todas as amostras foram tratadas com RNAse (10 $\left.\mathrm{mg} \mathrm{ml}^{-1}\right)$.

Para amplificar o DNA das bactérias endofíticas, reações de PCR foram realizadas em um volume final de $50 \mu \mathrm{L}$, contendo $5 \mu \mathrm{L}$ (10 ng) de DNA molde; 0,2 $\mu \mathrm{M}$ do iniciador F968 (5'-AACGCGAAGAACCTTAC -3') (Nubel et al, 1996) e do iniciador R1387 (5'-CGGTGTGTACAAGGCCCGGGAACG-3') (Heuer et al., 1997); $200 \mu \mathrm{M}$ de cada dNTP (Gibco BRL); 3,75 mM de MgCl; 0,5 U de Taq DNA polimerase (Life Technologies $\left.{ }^{\circledR}\right)$. Em todos os experimentos foi adicionada uma reação sem DNA como controle negativo. Foi utilizado termociclador (Gene AMP PCR System 9700) programado para gerar uma desnaturação inicial de $4 \min$ a $94^{\circ} \mathrm{C}$; 2 ciclos de $1 \mathrm{~min}$ a $94^{\circ} \mathrm{C}, 1 \mathrm{~min}$ a $60^{\circ} \mathrm{C}, 2 \min$ a $72^{\circ} \mathrm{C} ; 2$ ciclos de $1 \mathrm{~min}$ a $94^{\circ} \mathrm{C}, 1 \min 59^{\circ} \mathrm{C}, 2 \min$ a $72^{\circ} \mathrm{C} ; 2$ ciclos de $1 \mathrm{~min}$ a $94^{\circ} \mathrm{C}, 1 \mathrm{~min}$ a $58^{\circ} \mathrm{C}, 2 \mathrm{~min} 72^{\circ} \mathrm{C} ; 2$ ciclos de $1 \mathrm{~min}$ a $94^{\circ} \mathrm{C}, 1 \mathrm{~min}$ a $57^{\circ} \mathrm{C}$, $2 \min 72^{\circ} \mathrm{C}$; 2 ciclos de $1 \mathrm{~min}$ a $94^{\circ} \mathrm{C}, 1 \min 56^{\circ} \mathrm{C}, 2 \min 72^{\circ} \mathrm{C}$; 20 ciclos de $1 \mathrm{~min}$ a $94^{\circ} \mathrm{C}$, $1 \min 55^{\circ} \mathrm{C}$, $2 \min 72^{\circ} \mathrm{C}$, e uma extensão final de $10 \min$ a $72^{\circ} \mathrm{C}$. Foram utilizados $5 \mu \mathrm{L}$ da reação de PCR para a observação em gel de agarose $(1,2 \%)$ de um fragmento de aproximadamente 450 pb. O produto do PCR foi purificado com o kit (Ultra Clean PCR clen-up) de acordo com as instruções do fabricante e sequenciado com o primer R1387. 
As identificações foram realizadas pelo sequenciamento de genes, pela amplificação do gene que codifica a subnidade 16S do RNA ribossômico em termociclador (Gene AMP PCRSystem 9700) de 67 bactérias endofíticas isoladas da mandioca. As amostras foram seqüenciadas e depois analisadas por meio do BLASTn (http://www.ncbi.nlm.nih.gov/BLAST), contra a base de dados (GenBank), onde foi observada a similaridade destas seqüências com o 16S rDNA de espécies já depositadas nesta base de dados.

\subsection{Identificação da bactéria selecionada por análise de ácidos graxos}

Isolados de bactérias endofíticas foram identificadas através do perfil de ácidos graxos do envoltório celular, por cromatografia gasosa modelo 6850 Agilent.

O sistema de Identificação Microbiano Sherlock (MIS) (MIDI, Inc., Neward, EUA) analisa e identifica microrganismos isolados de cultura pura em meio artificial. O Sherlok usa um procedimento de preparação de amostras e cromatografia gasosa para qualificar e quantificar a composição do perfil de ácidos graxos que compõem a membrana celular de microrganismos desconhecidos, comparando estes com a biblioteca (de perfil de linhagens referentes) armazenada no computador.

Para a extração de ácidos graxos há cinco etapas: Coleta - recomendada que seja feita no $3^{\circ}$ quadrante, aproximadamente quatro alças. Saponificação - o reagente de saponificação (metanol, $\mathrm{NaOH}, \mathrm{H}_{2} \mathrm{O}$ ) e alta temperatura provocam a morte e lise das células. Metilação - converte os ácidos graxos em metil ésteres de ácidos graxos, que apresentarão maior volatilidade para análise de cromatografia gasosa. Extração - metil ésteres de ácidos graxos são removidos da fase aquosa e transferidos para a fase orgânica pelo procedimento de extração líquido-líquido. Lavagem - o reagente de lavagem é adicionado para remover ácidos graxos livres e resíduos de reagentes.

Para identificação das bactérias endofíticas utilizando o padrão de ácidos graxos, estas foram cultivadas em meio TSA, pelo método de estrias cruzadas e incubadas a $28 \pm$ $1^{\circ} \mathrm{C}$, por $24 \pm 2$ horas. Decorrido este tempo, foram coletados, aproximadamente, $40 \mathrm{mg}$ (quatro a seis alças com capacidade para $10 \mu \mathrm{L}$ ) da cultura no $3^{\circ}$ quadrante e transferidos para tubos Kimax (100X13 mm). Depois, foram executadas as quatro etapas para 
extração dos ácidos graxos celulares (saponificação, metilação, extração e lavagem). Foi utilizado o cromatógrafo gasoso com injetor automático (modelo 6850, Agilent), e detector Flame Ionization Detector (FID) (modelo 7683 Agilent). A interface foi obtida pelos programas ChemStation A. 09.01[1206] e o método e a biblioteca selecionada foram TSBA 40.

\subsection{Análise de Biomassa do Bacillus pumilus}

O aumento da biomassa total da bactéria, Bacillus pumilus cultivada em diferentes meios líquidos (Caldo Nutriente, Nutriente Ágar, LB, Czapek e BDA) pôde ser monitorado por medidas da densidade óptica da cultura. Alíquotas da cultura em crescimento foram retiradas em determinados intervalos de tempo (0, 6, 24, 48, 72 horas) e mediu-se então a absorbância da cultura contra um comprimento de onda de 600 nm (Perkin-Elmer, Mod. Lambda 20) em uma cubeta de quartzo de $1 \mathrm{~mL}$. Para tal utilizou-se um espectrofotômetro "zerado" com meio de cultura isento de inóculo que é denominado "branco".

Cada medida obtida correspondeu à densidade óptica (DO) da cultura em um dado momento do crescimento. A absorbância aumentou proporcionalmente ao aumento do número de células (biomassa) no meio de cultura.

\subsection{Obtenção de extratos orgânicos de Bacillus pumilus}

Bacillus pumilus foi cultivada em meio líquido (BD). O meio (5500 mL) foi incubado em um shaker - $28^{\circ} \mathrm{C} / 150 \mathrm{rpm}$ - cerca de 72, horas aproximadamente. Após o crescimento da bactéria, o meio com a bactéria crescida, foi centrifugado em centrífuga refrigerada SORVALL (10000 rpm a $28^{\circ} \mathrm{C}$ ), para se obter os componentes liberados pelo metabolismo da bactéria presentes no sobrenadante, sendo o resíduo sólido descartado.

Dos $5000 \mathrm{~mL}$ do sobrenadante, foram utilizadas alíquotas de $500 \mathrm{~mL}$ de cada vez para as sucessivas extrações com hexano $(200 \mathrm{~mL})$, diclorometano $(200 \mathrm{~mL})$ e acetato de etila (200 mL) em funil de separação (Fig.2). Esse processo foi repetido três vezes para cada operação. As respectivas fases orgânicas foram reunidas e secas com sulfato de sódio anidro. Após a filtração e evaporação do solvente em evaporador rotatório, 
obteve-se os extratos brutos: hexânico (EB1- 7mg), diclorometânico (EB2- 8mg) e acetato de etila (EB3- 8mg).

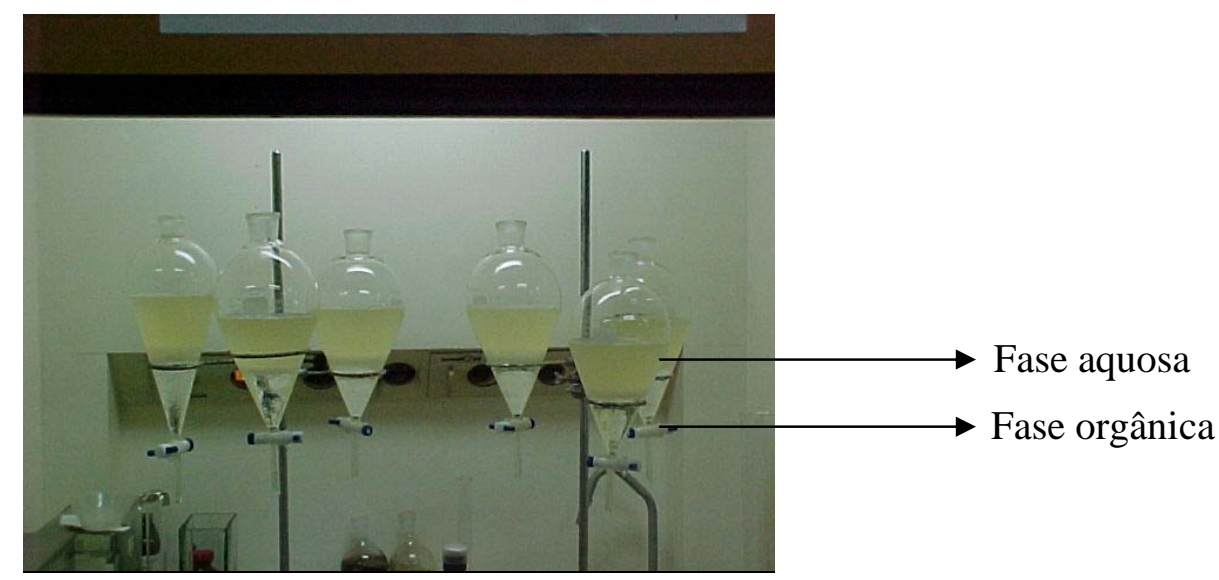

Figura 2 - Extração dos metabólitos secundários da bactéria selecionada com diferentes solventes: Hexano, Dicloromentano e Acetato de etila.

\subsection{Teste de antibiose utilizando-se os extratos EB-1, EB-2 e EB-3.}

Rhizoctonia, Pythium e Sclerotium rolfsii foram inoculados em meio BDA em placa à $25^{\circ} \mathrm{C}$ por 24 horas, separadamente. Após crescimento inicial, $20 \mu \mathrm{L}$ dos extratos EB-1, EB-2 e EB-3, produzido pela bactéria endofítica MAIIIM4a, Bacillus pumilus, foram aplicados em discos S\&S (diâmetro 1/4 IN) autoclavados para análise de antibióticos, previamente inseridos em placas de Petri contendo os fungos fitopatogênicos. Após dois dias observou-se se houve ou não a formação de halos de inibição. O procedimento foi feito em triplicata para cada um dos fungos fitopatogênicos em estudo.

\subsection{Análise dos extratos orgânicos das bactérias endofíticas por métodos cromatográficos}

\subsubsection{Cromatografia em Camada delgada}

A cromatografia em camada delgada (CCD) foi realizada para avaliação analítica qualitativa dos componentes dos extratos EB-1, EB-2 e EB-3, utilizando-se cromatoplacas de sílica $\mathrm{GF}_{254}$ em suporte de alumínio, da MERCK. Os extratos (EB-1, EB-2 e EB-3) foram aplicados nas cromatoplacas na quantidade máxima de 10 L, tendo 
sido aplicado o controle (extrato do meio de cultura) como referência. O eluente usado para o desenvolvimento dos cromatogramas foi diclorometano/acetato de etila (9:1). As manchas foram identificadas sob luz ultravioleta no comprimento de onda de $254 \mathrm{~nm}$ e 366 nm e o cálculo dos Rfs (frente de retenção) realizado, segundo a seguinte equação:

$\mathrm{R}_{\mathrm{f}}=$ Distância do centro da mancha à linha de partida

Distância da frente do eluente à linha de partida

A análise foi feita observando-se a velocidade de migração dos constituintes da mistura e que foram caracterizados por um valor numérico, $\mathrm{R}_{\mathrm{f}}$, que exprime a relação entre as distâncias percorridas pelo composto e pela frente do solvente.

\subsubsection{Bioautografia}

Para testar a atividade dos compostos presentes no cromatograma, inoculou-se uma suspensão de $10^{6}$ celsmL $^{-1}$ do fungos testes em $20 \mathrm{~mL}$ de meio de cultura BDA ainda líquido e pulverizou-se o cromatograma o qual foi colocado em uma placa de Petri de 90mm de diâmetro. A placa contendo o cromatograma pulverizado com a suspensão dos fungos testes foi incubada a $25^{\circ} \mathrm{C}$. Observou-se diariamente o crescimento desses fungos testes, verificando-se a formação de halo de inibição sobre alguns componentes das frações obtidas pelas cromatografias realizadas.

- Fungos testados: Aspergillus niger, Fusarium moniliforme e Fusarium oxysporium

\subsubsection{Cromatografia em coluna}

O extrato em acetato de etila EB-3 foi fracionado em coluna de SEPHADEX-LH 20 (polímero gelatinoso), usando hexano, diclorometano e acetona nas proporções de 1,5: 2:0,5. Das 50 frações obtidas, fez-se cromatografia em camada delgada e estas foram agrupadas de acordo com a semelhança das frações, quando visualizadas em câmara UV e também quando reveladas por reveladores químicos (Fig.3).

A fase móvel, quando está passando através do adsorvente na coluna, arrasta consigo os componentes da amostra que está sendo cromatografada. Quanto maior a diferença entre os coeficientes de adsorção, mais completa será a separação do composto 
(terá maior grau de pureza). A separação dos componentes de uma mistura é devido às diferenças nas forças de adsorção entre cada componente. Quanto menor for a afinidade de um dado soluto com a fase estacionária, menor é o tempo que o mesmo despende durante o fenômeno de eluição.

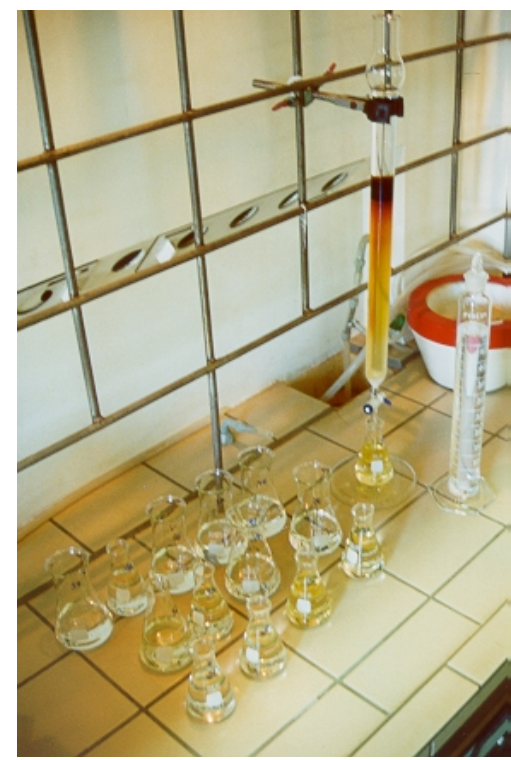

Figura 3 - Frações coletadas pela técnica de cromatografia em coluna

\subsubsection{Derivatização das amostras dos extratos brutos com Diazometano $\left(\mathrm{CH}_{2} \mathrm{~N}_{2}\right)$ para posterior análise no CG-EM}

Os extratos brutos (extrato hexânico - EB1, extrato diclorometânico - EB 2, e extrato de acetato de etila - EB 3) foram submetidos à prévia metilação com diazometano para posterior análise no CG-EM.

\subsubsection{Preparação do Diazometano}

Para se preparar diazometano utilizou-se o esquema mostrado na Fig. 4. No balão foram dissolvidos 5,0 g de hidróxido de potássio em 8,0 $\mathrm{mL}$ de água destilada. Após a adição de $25 \mathrm{~mL}$ de etanol, esta solução (solução A) foi aquecida a $65^{\circ} \mathrm{C}$ em um banho 
de água, 21,0 g de Diazald ${ }^{\circledR}$ e 200,0 mL de éter etílico foram adicionados a um funil de adição (solução B). A solução B foi adicionada lentamente à solução A, a uma temperatura constante de $65^{\circ} \mathrm{C}$. O frasco Erlenmeyer e o kitassato foram envolvidos em papel alumínio e obrigatoriamente em banho de gelo.

Esse reagente é extremamente tóxico e explosivo e deve ser armazenado no freezer. O diazometano residual pode ser destruído com etanol ou ácido acético.

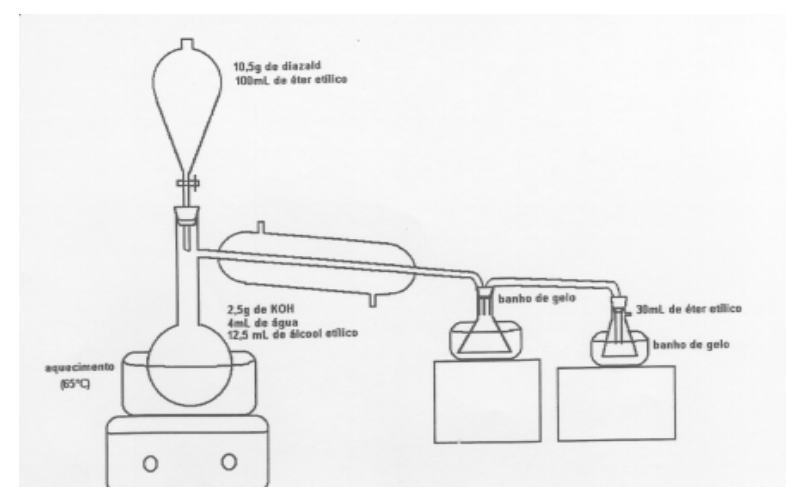

Figura 4 - Equipamento utilizado na preparação do Diazometano

\subsubsection{Metilação dos extratos com diazometano}

Cerca de $10 \mathrm{mg}$ dos extratos (EB -1, EB -2 e EB -3) foram dissolvidos em 1,0 mL de éter etílico, separadamente, e resfriados em banho de gelo por 10 minutos. A solução etérea contendo o diazometano foi adicionada lentamente aos extratos, em um intervalo de 15 - 20 minutos. A completa metilação destes extratos foi confirmada por CCD.

\subsubsection{Análise por cromatografia gasosa acoplada ao espectrômetro de massa (CG-EM)}

As análises por CG-EM foram realizadas utilizando-se um cromatógrafo a gás modelo Shimadzu acoplado a um detector seletivo de massas QP-5000 cuja fonte de impacto de elétrons opera com energia de ionização de 70 eV. No CG foi utilizada uma 
coluna capilar de sílica fundida DB-5 (30 m x 0,25 mm x 0,25 $\mu \mathrm{m}$ ). Utilizou-se Hélio como gás de arraste $\left(1 \mathrm{mlmin}^{-1}\right)$ e split $1 / 20$. As injeções foram da ordem de $1 \mu \mathrm{L}$ de solução $\left(10 \mathrm{mgml}^{-1}\right)$.

As programações de temperatura empregadas foram as seguintes:

- Temperatura do injetor: $240^{\circ} \mathrm{C}$;

- Temperatura do detector: $230^{\circ} \mathrm{C}$;

- Faixa de massas: 40- $550 \mathrm{~nm}$

- Programação de temperatura: $40^{\circ} \mathrm{C}-280^{\circ} \mathrm{C}\left(10^{\prime}\right) ; 8^{\circ} \mathrm{Cmin}^{-1}$.

Os extratos, através de um sistema de injeção, foram introduzidos em uma coluna contendo a fase estacionária. O uso de temperaturas convenientes no local de injeção da amostra e na coluna possibilitou a vaporização desta substância que, de acordo com suas propriedades e as da fase estacionária, são retidas por tempos determinados e chegam á saída da coluna em tempos diferentes. O uso de um detector adequado na saída da coluna torna possível a detecção e quantificação destas substâncias. A cromatografia gasosa é, atualmente, uma das técnicas de analise de maior uso. O uso de um espectrômetro de massas acoplado ao cromatógrafo a gás (CG-EM) permitiu a identificação de quase todos os compostos (exceto isômeros), em nível de microgramas. A identificação dos possíveis metabólitos presentes nos extratos foi feita através da comparação de seus espectros de massas com dados da biblioteca Nist 12 e Wiley. Também procedeu - se a extração do meio de cultura sem a bactéria, que serviu como controle.

\subsubsection{Cromatografia Líquida acoplada ao espectrômetro de massas}

As análises por cromatografia líquida acoplada ao espectrômetro de massas foram realizadas através da infusão continua de amostra empregando uma bomba de seringa. Os espectros foram obtidos em espectrômetro de massas QTof II (Micromass, Manchester, UK) operando com interface electrospray em modo positivo e negativo. As temperaturas da fonte e do gás de desolvatação foram 100 e $200^{\circ} \mathrm{C}$, respectivamente. Os espectros EM, tanto em modo positivo quanto modo negativo, foram obtidos em 
condições experimentais idênticas, para capilrary 3200 kV, voltagem do cone 25 V. A faixa de varredura para os espectros de EM foi de 100-2000 m/z. Para os espectros EM/EM foi feita uma varredura da energia de colisão entre 10-45 eV tendo argônio como gás de colisão.

\subsection{Inoculação da suspensão de Bacillus pumilus em plantas de mandioca obtidas pela técnica de cultura de tecidos}

Plantas de mandioca livres de microrganismos foram obtidas pela técnica de cultura de tecidos - uma técnica destinada a crescer células de um organismo multicelular em um meio líquido ou sólido para pesquisa (Fig. 5). Particularmente no caso de vegetais, cultura de tecidos consiste em um conjunto de técnicas que compreendem desde o crescimento de células até a regeneração in vitro de plantas inteiras a partir de células, tecidos ou órgãos.

Em câmara de fluxo laminar preparou-se uma suspensão bacteriana de $10^{8}$ celsmL $^{-1}$ quantificada em espectrofotômetro (Perki Elmer) com absorbância de 530 nm em 9 mL de solução salina. Após a preparação da suspensão bacteriana inoculou-se esta em 6 vidros autoclavados; 3 vidros contendo $400 \mathrm{~mL}$ de água mineral autoclavada e 3 vidros contendo $400 \mathrm{~mL}$ de meio de cultura Murashige \& Skoog autoclavado. Após este procedimento as plantas de mandioca obtidas pela técnica de cultura de tecidos foram lavadas com solução salina e transplantadas para os 6 vidros contendo as soluções com a suspensão bacteriana (Fig. 6). Após 5 dias retirou-se as diferentes partes da planta e as preparou para que se observasse a colonização da bactéria endofítica pela técnica de microscopia eletrônica de varredura (Fig. 7). 


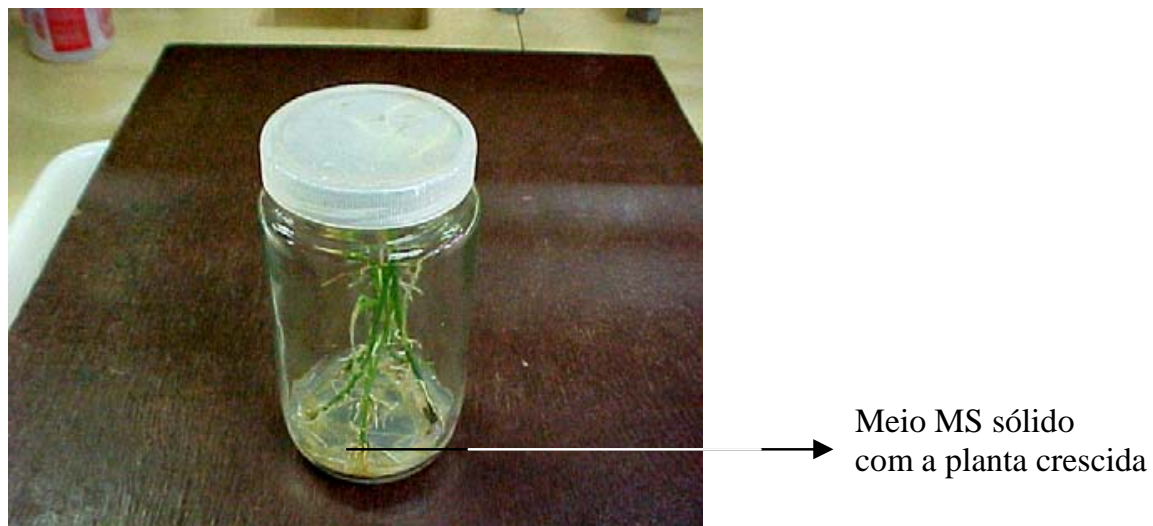

Figura 5 - Planta de mandioca cultivada em meio MS (Murashige, T \& SKOOG).
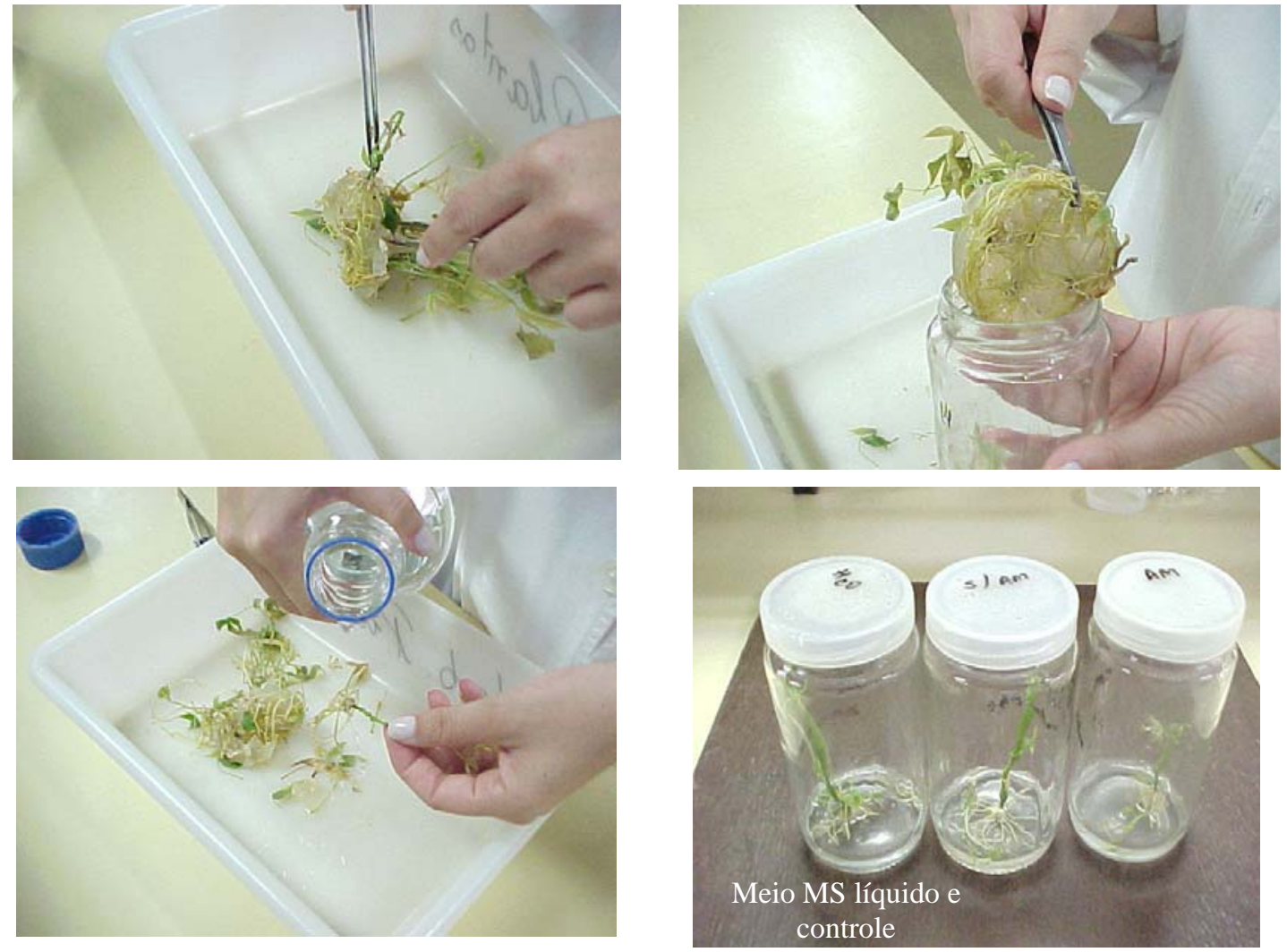

Figura 6 - Transferência da planta do meio sólido, limpeza das plantas com água esterilizada e inoculação das plantas em meio MS líquido. 

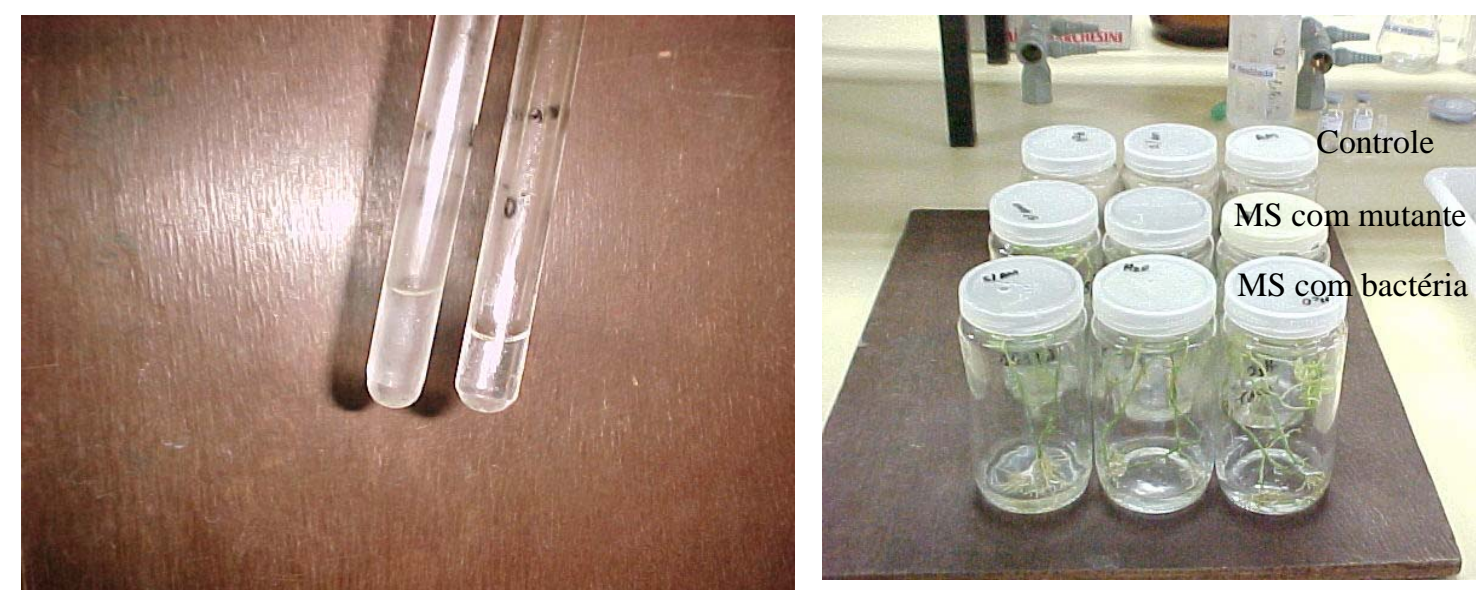

Figura 7 - Inoculação de $10^{8}$ cels/mL da bactéria no meio MS líquido para posterior observação da colonização nas diferentes partes da planta.

\subsubsection{Preparação da amostra para microscopia eletrônica}

Retirou-se as plantas, que foram colonizadas pela bactéria Bacillus pumilus in vitro e cortou-se os fragmentos em aproximadamente $2 \times 2 \mathrm{~cm}$ de folhas, manivas e raiz de cada amostra, com estilete esterelizado. Os fragmentos foram fixados usando a solução Karnovksy modificada e armazenou as amostras fixadas com a solução, na geladeira por uma noite.

\subsubsection{Solução Karnovksy modificado (Técnica padrão segundo Kitajima \& Leite,} 1999)

Glutaraldeído 2,5\%

Formaldeído 2,5\%

Tampão cacodilato de sódio 0,05 M, pH 7,2

$\mathrm{CaCl}_{2}$ 0,001 M

- Lavou-se 3 vezes cada amostra com tampão cacodilato (0,05 M) por 10 minutos. Foi preparado para este experimento $50 \mathrm{~mL}$ do tampão para as lavagens;

- Seccionou-se as amostras para exposição do interior dos tecidos (Fig. 8);

- Após as lavagens preparou-se $\mathrm{OsO}_{4}$ 1\% (Tamponado em tampão cacodilato 0,05 M, pH 7,2) para a fixação das amostras, onde permaneceu por 1 hora; 
-Lavou-se as amostras 5 vezes com água destilada em intervalos de 15 minutos para cada lavada.

- Após sucessivas lavagens desidratou-se as amostras em série crescente de acetona (30, 50, 70, 90 e 100\%) por 15 minutos cada. A última etapa repetiu-se 3 vezes.

- Após as desidratações com acetona secou-se as amostras ao ponto crítico e metalizou durante 3 minutos com o gás argônio.

Depois da metalização das amostras, estas foram guardadas em dessecador para posterior análise em MEV.
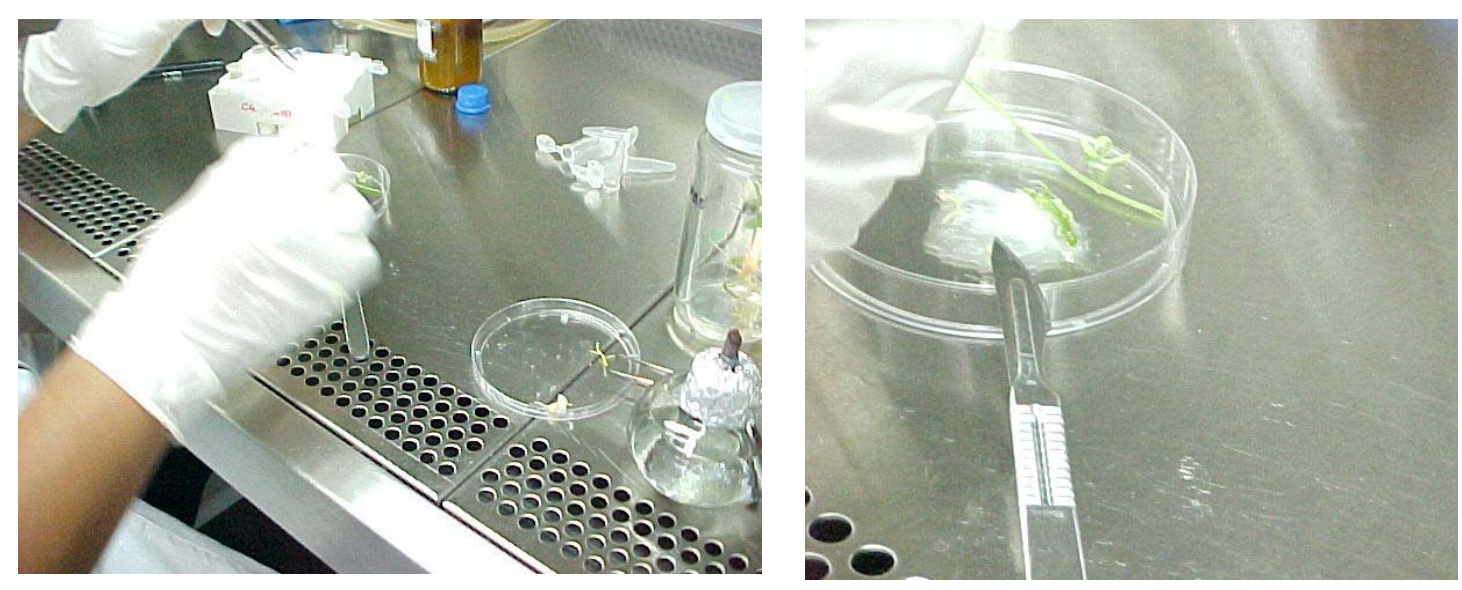

Figura 8 - Secção das amostras em fragmentos pequenos (2x2) e fixadas em solução Karnovksy modificado.

\subsection{Resistência do Bacillus pumilus a diferentes antibióticos em diferentes concentrações}

Para a obtenção de mutantes, a bactéria Bacillus pumilus, MAIIIM4a foi colocada em placas contendo meio de cultura Nutriente Ágar com diferentes antibióticos cada, Ácidos Nalidíxico, Rifampicina, Tetraciclina, Eritromicina e Penicilina em concentrações de 50/100/150 ppm. As placas com meio de cultura NA contendo os antibióticos e a bactéria inoculada foi incubada na temperatura de $28^{\circ} \mathrm{C}$ por 
aproximadamente três dias, até o aparecimento de colônias. O experimento foi realizado em triplicata. Diz-se que uma bactéria é resistente a um antibiótico quando consegue sobreviver e multiplicar-se na sua presença. Por outro lado, se não consegue multiplicarse na presença de um antibiótico, apesar de conseguir sobreviver, diz-se tolerante. Acredita-se que a tolerância a um antibiótico seja um passo intermediário no sentido da resistência. 


\section{RESULTADOS E DISCUSSÃO}

\subsection{Coleta e isolamento de bactérias endofíticas de mandioca}

Um total de 67 bactérias endofíticas foram isoladas de cerca de 6 plantas de mandioca coletadas no estado da Amazônia (Tabela 1). Este isolamento provavelmente subestima a população total de microrganismos, em termos de diversidade, uma vez que foram somente selecionadas as bactérias capazes de se desenvolverem nos meios de cultura utilizados. Tais limitações se aplicam à maioria dos estudos baseados em métodos de plaqueamento, embora eles forneçam indicações relativas da estrutura da população microbiana.

Tabela 1 - Bactérias endofíticas isoladas de variedades selvagens de mandioca da Amazônia.

\begin{tabular}{cccccc}
\hline Região & Microrganismo & Raízes & Manivas & Folhas & Total \\
\hline Amazônia & Bactérias & 19 & 26 & 22 & 67 \\
\hline
\end{tabular}

\subsection{Métodos de identificação utilizando perfil de ácidos graxos (FAME) e o gene 16s rDNA.}

Os resultados relacionados à taxonomia mostraram que dos 67 isolados submetidos a identificação utilizando o gene 16S rDNA e por análise de ácidos graxos, apenas 37 apresentaram similaridade satisfatória nas duas técnicas moleculares (Tabela 2). As plantas de mandioca coletadas no estado do Amazonas apresentaram grande diversidade de bactérias endofíticas, com 17 gêneros identificados, ou seja: Bacillus, Enterobacter, Stenotrophomonas, Salmonella, Serratia, Burkholderia, Kluyvera, Brevibacillus, Streptomyces, Brachybacterium, Clavibacter, Klebsiella, Acidovorax, Microbacterium, Pseudomonas, Ralstonia e Bradyrhizobium, Curtobacterium (Tabela 3). 
Tabela 2 - Identificação de algumas bactérias endofíticas, por FAME e por análise do gene 16S rDNA.

\begin{tabular}{|c|c|c|}
\hline Código & Identificação & Técnica \\
\hline MAIIR2b & Kluyvera cryocrescens & FAME \\
\hline MAIVR1b & B. cereus-GC-subgrupo A & FAME \\
\hline MAIVR2a & Streptomyces olivaceus & 16S rDNA \\
\hline MAIIIR1b & Bacillus cereus & 16S rDNA e FAME \\
\hline MAIIIR3b & Stenotrophomonas malttophilia & $16 \mathrm{~S}$ rDNA \\
\hline MAIR1b & B. cereus-GC-subgrupo A & FAME \\
\hline MAIIR1a & B. cereus-GC-subgrupo A & FAME \\
\hline MAIVR3b & Burkholderia cepacia & 16S rDNA \\
\hline MAIIIR4a & Enterobacter aerogenes & 16S rDNA e FAME \\
\hline MAIR2f & Burkholderia cepacia-GC-subgrupo B & FAME \\
\hline MAIIIR4a-b & Klebsiella penumoniae-GC-subgrupo B & FAME \\
\hline MAIR2b & Bacillus cereus & 16S rDNA \\
\hline MAIIIR4b & Acidovorax avenae-avenae & FAME \\
\hline MAIIIR2a & Stenotrophomonas maltophilia & FAME \\
\hline MAIIIR2b & Burkholderia cepacia GC subgrupo B & FAME \\
\hline MAIR2a & Bacillus cereus & 16S rDNA \\
\hline MAIIIR3a & Bradyrhizobium japonicum GC subgrupo A & FAME \\
\hline MAIIIM2b & Bacillus antracis & $16 \mathrm{~S}$ rDNA \\
\hline MAIM1b & Brachybacterium paraconglomeratum & $16 \mathrm{~S}$ rDNA \\
\hline MAIIIM2a & Enterobacter aerogenes & $16 \mathrm{~S}$ rDNA \\
\hline MAIVMЗа & Bacillus anthracis & 16S rDNA \\
\hline MAIIIM1a & Salmonella enteritidis & FAME \\
\hline MAIMЗa & Brevibacillus brevi & FAME \\
\hline MAIVM2a & Enterobacter cancerogenus & FAME \\
\hline MAIIM2b & Salmonella bongori & FAME \\
\hline MAIIIM4a & B. pumilus subgrupo B & FAME e 16s rDNA \\
\hline MAIVM2b & Salmonella choleraesius & FAME \\
\hline MAIM1b & Rastonia sp. & 16S rDNA \\
\hline MAIF2b & B.cereus-GC-subgrupo A & FAME \\
\hline MAIIIF1a & Stenotrophomonas maltophilia & 16S rDNA \\
\hline MAIF2b & B. cereus - GC-subgrupo A & FAME \\
\hline MAIF6b & Clavibacter michiganensis isidiosum & FAME \\
\hline MAIIIF2b & Curtobacterium luteum & $16 \mathrm{~S}$ rDNA \\
\hline MAIF1b & Bacillus pumilus & 16S rDNA \\
\hline MAIF1a & Microbacterium aerborescens & 16S rDNA \\
\hline MAIVR1f & Pseudomonas rhodesiae & 16S rDNA \\
\hline MAIIIR1f & Enterobacter cloacae & 16S rDNA \\
\hline
\end{tabular}

As espécies de bactérias acima foram codificadas de acordo com a colonização nos tecidos, R- Raiz / M- Manivas / F- Folhas, no estado da Amazônia. 
Após a triagem das bactérias endofíticas pelo teste de antagonismo (ver item abaixo) frente aos diferentes fitopatógenos, procedeu-se novamente a identificação da bactéria MAIIIM4a pela técnica de análise de ácidos graxos, para se ter a confirmação da linhagem com forte potencial inibitório. Uma vez confirmada a identificação, conforme Tabela 2.1, esta bactéria endofítica foi alvo dos demais estudos realizados.

Tabela 2.1 - Análise da linhagem MAIIIM4a pela técnica de análise de ácidos graxos (FAME).

\begin{tabular}{|c|c|c|c|c|c|c|}
\hline $\begin{array}{l}\text { Tempo de } \\
\text { Retenção }\end{array}$ & Resposta & Área/Altura & RFact & ECL & Nomes dos Picos & $\begin{array}{l}\text { Porcentagem } \\
\text { (\%) }\end{array}$ \\
\hline 1,705 & $3,593 \mathrm{E}+8$ & 0,029 & ---- & 7,014 & SOLVENT & $\begin{array}{ll}--- \\
\end{array}$ \\
\hline 1,813 & 4159 & 0,023 & $\begin{array}{ll}--- \\
\end{array}$ & 7,230 & & $\begin{array}{ll}--- \\
\end{array}$ \\
\hline 6,797 & 874 & 0,035 & 0,993 & 13,619 & 14:0 ISO & 0,76 \\
\hline 7,316 & 1420 & 0,038 & 0,982 & 13,999 & $14: 0$ & 1,22 \\
\hline 8,277 & 50981 & 0,040 & 0,967 & 14,624 & 15:0 ISO & 43,20 \\
\hline 8,415 & 26540 & 0,039 & 0,965 & 14,714 & 15:0 ANTEISO & 22,44 \\
\hline 9,505 & 627 & 0,041 & 0,952 & 15,389 & 16:1 w7c alcohol & 0,52 \\
\hline 9,901 & 2546 & 0,043 & 0,948 & 15,627 & 16:0 ISO & 2,11 \\
\hline 10,121 & 2795 & 0,043 & 0,946 & 15,759 & $16: 1 \mathrm{w} 11 \mathrm{c}$ & 2,32 \\
\hline 10,521 & 7206 & 0,044 & 0,942 & 15,999 & $16: 0$ & 5,95 \\
\hline 11,198 & 3282 & 0,044 & 0,937 & 16,390 & ISO $17: 1 \mathrm{w} 10 \mathrm{c}$ & 2,69 \\
\hline 11,351 & 776 & 0,042 & 0,936 & 16,478 & Sum In Feature 4 & 0,64 \\
\hline 11,615 & 14403 & 0,044 & 0,934 & 16,631 & 17:0 ISO & 11,79 \\
\hline 11,775 & 7760 & 0,044 & 0,933 & 16,723 & 17:0 ANTEISO & 6,35 \\
\hline \multirow[t]{3}{*}{---} & 776 & --- & ---- & ---- & Summed Feature 4 & 0,64 \\
\hline & \multicolumn{2}{|c|}{ Biblioteca } & & \multicolumn{2}{|c|}{ Nome encontrado } & \\
\hline & \multicolumn{2}{|c|}{ TSBA50 5.00} & & Bacillus- $p$ & -GC & \\
\hline
\end{tabular}

O resultado final acima foi apresentado de acordo com a similaridade entre o banco de dados e as áreas nomeadas, identificando dessa forma, a bactéria em questão. Baseado na composição dos ácidos graxos das bactérias foi construído um dendograma com os isolados de Bacillus obtidos nos três estados Amazonas, São Paulo e Bahia (Figura 9). Os perfis FAME indicaram que os isolados de B. pumilus de São Paulo (AMCCA36b, AMCAC12) são da mesma subespécie ou biotipo. O isolado do Amazonas (MAIIIM4a) assemelhou-se aos de São Paulo somente em nível de espécie. No dendograma também foi verificado que existe similaridade entre os isolados dos três estados em nível de espécie, subespécie ou biótipo. 


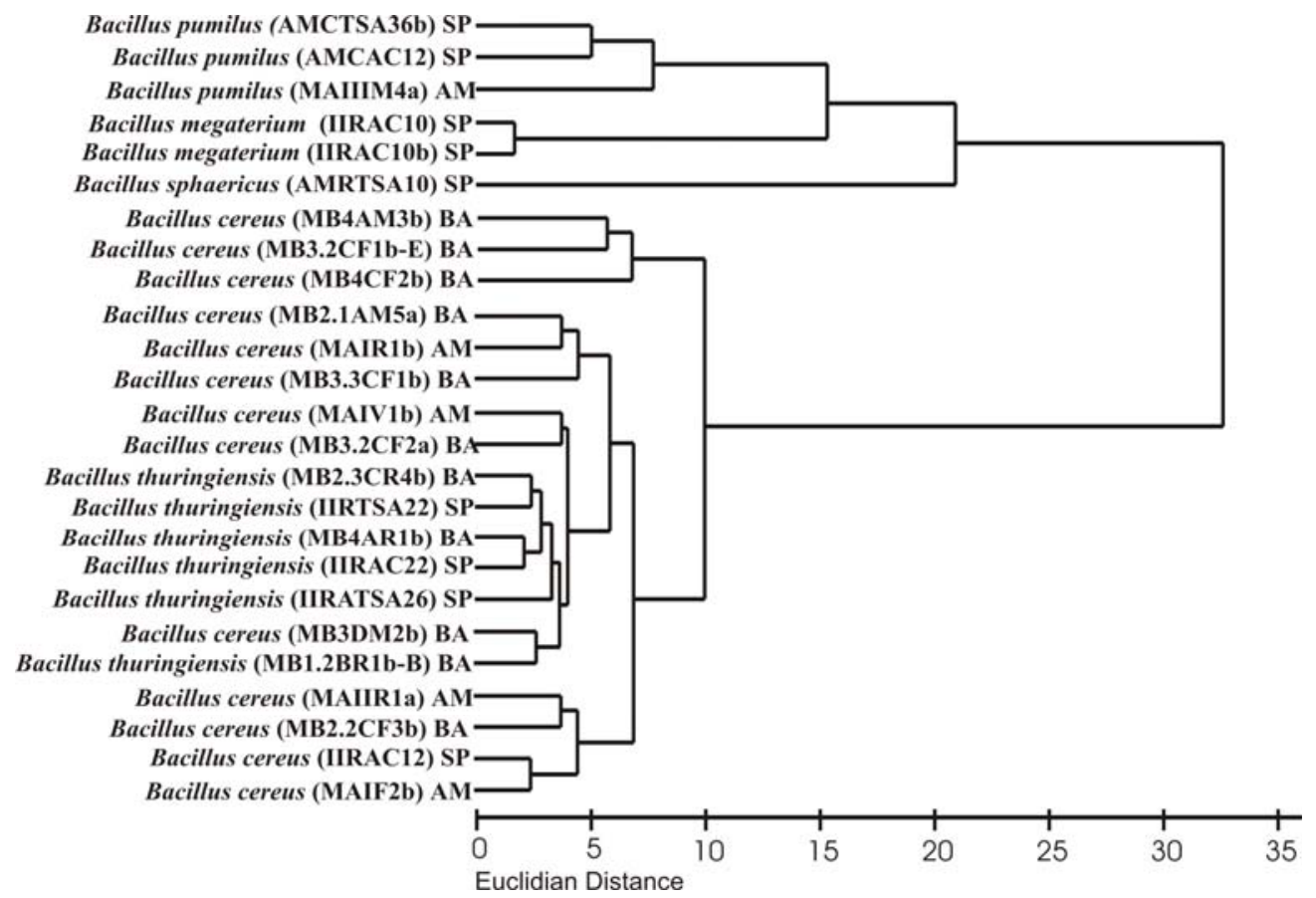

Figura 9 - Dendrograma baseado na composição de ácidos graxos das bactérias do gênero Bacillus

A seqüência parcial de nucleotídeos obtida usando os iniciadores F968/R1387, cujo tamanho esperado era de aproximadamente 450 pb, foi de 366 pb devido à baixa qualidade das extremidades dessa sequiência, as quais foram retiradas. Essa seqüência apresentou $98 \%$ de identidade com seqüências de Bacillus pumilus (AF526907, AY289549, AY496869, AY167886) pela análise BLAST.

Identidade de sequiência de $16 \mathrm{~S}$ rRNA acima de 97,5\% indica que a linhagem pertence a mesma espécie (Stackebrandt \& Goebel 1994). Assim, baseando-se nesse resultado e no obtido pela análise FAME pode-se dizer que o organismo isolado é o Bacillus pumilus, porém, deve ser uma nova linhagem. As relações filogenéticas da seqüência obtida com outras depositadas no GenBank (Fig. 10) e analisadas por meio do método da distância ("neighbor-joining”) mostraram que a bactéria isolada neste estudo forma um clado monofilético com todos os Bacillus pumilus selecionados do GenBank. Entretanto, a seqüência dessa bactéria apresenta uma maior distância evolutiva quando comparada com as dos outros quatro Bacillus pumilus analisados. Isso é evidenciado pelo tamanho do ramo formado na árvore filogenética. Esse fato também reforça a idéia de que essa bactéria representa uma nova linhagem. 


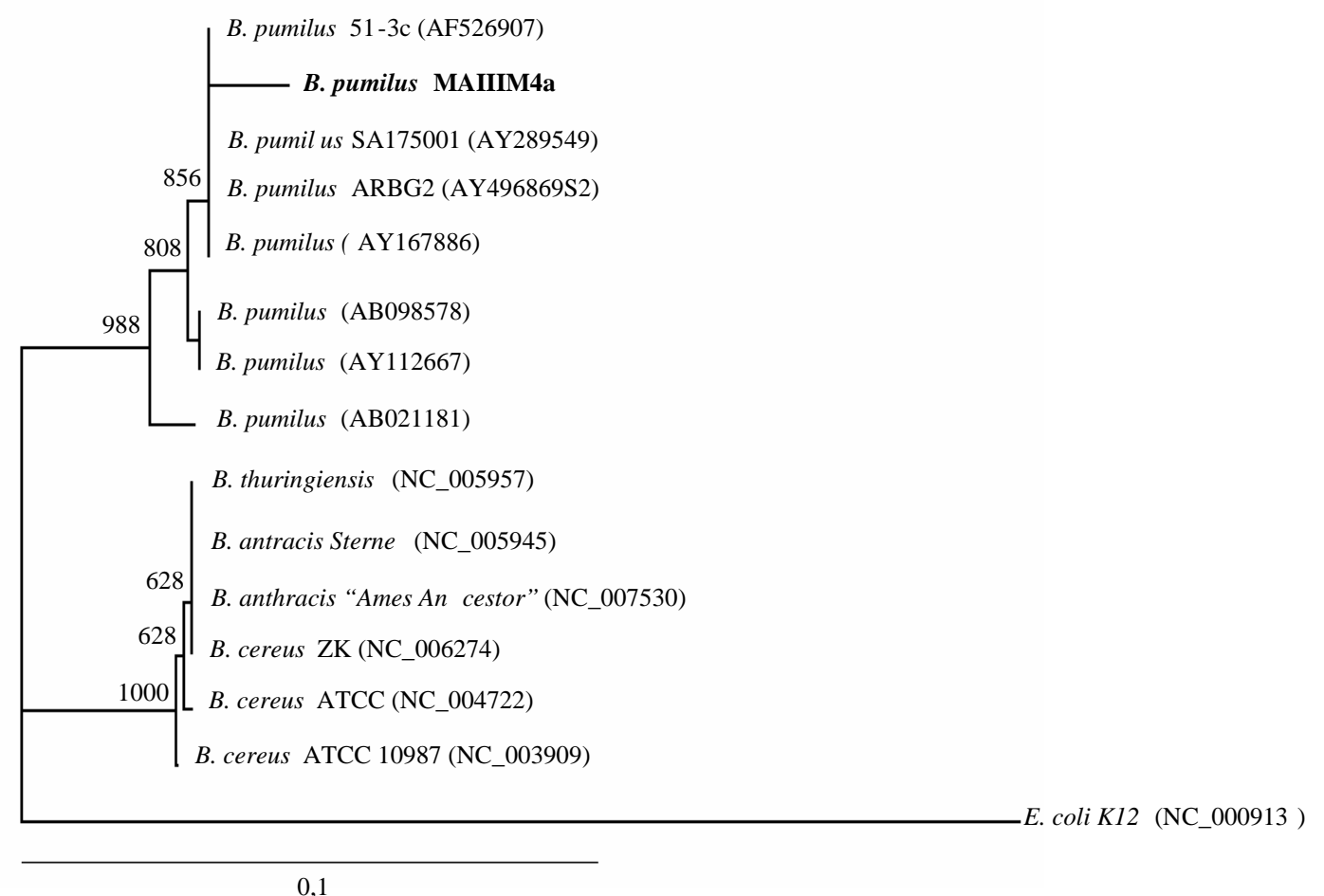

Figura 10 - Relações filogenéticas entre a seqüência parcial de 16S rRNA do endofítico B. pumilus MAIIIM4a e de outras linhagens de Bacillus retiradas do GenBank. O organismo cuja região do 16S rRNA foi seqüenciada neste estudo está em negrito. A árvore foi enraizada usando a região do 16S rRNA de Escherichia coli como um grupo externo. Valores superiores a 50\% na reamostragem de 1000 árvores são indicados nos clados.

\subsection{Colonização da bactéria endofíticas em diferentes partes da mandioca}

As bactérias endofíticas das plantas de mandioca mostraram-se capazes de colonizar todos os tecidos da planta. No tecido radicular foram obtidos cerca de $28 \%$ do total de bactérias isoladas, seguido pelo caule com, aproximadamente, 39\% e pelas folhas, com $32 \%$. A presença de alguns dos gêneros encontrados são comuns em todas as partes da planta, enquanto outros são mais específicos (Tabela 3).

Na mandioca proveniente da Amazônia o gênero Bacillus identificado foi encontrado com 32\% de freqüência, ao passo que estudos realizados em outros dois estados Bahia e São Paulo obtiveram-se uma freqüência de 64\% e 53\% respectivamente. 
De 12 isolados e identificados do gênero Bacillus, 67\% eram pertencentes à espécie $B$. cereus e $17 \%$ à espécie B. pumilus, os outros $17 \%$ pertencentes a espécie $B$. anthracis,. Embora a maior diversidade de gêneros de bactérias endofíticas fosse encontrada no Estado do Amazonas, a maior diversidade de espécies de Bacillus foi encontrado no Estado de São Paulo (Gomes, 1987).Alguns trabalhos relatam o gênero Bacillus como a principal bactéria endofítica de determinadas plantas (Hallmann et al., 1997). As espécies de Bacillus mais freqüentemente citadas como endófitos são: Bacillus cereus (Araújo et al., 2002, Araújo et al., 2001, Pleban et al., 1995), Bacillus subtilis (Bai et al., 2002, Araújo et al., 2001), Bacillus megaterium (Sturz et al., 1997, Elvira-Recuenco \& van Vuurde, 2000, Araújo et al., 2001), Bacillus insolitus (Sturz et al., 1997), Bacillus brevis (Sturz et al., 1997), Bacillus pumilus (Araújo et al., 2002, Araújo et al., 2001) e Bacillus lentus (Araújo et al., 2001), sendo encontradas nas mais diversas espécies vegetais tais como: Zea mays L. (Lalande et al., 1989), Gossypium hirsutum L. (Misaghi \& Donndelinger, 1990), Beta vulgaris (Jacobs et al., 1985), e Solanum tuberosum L. (Hollis 1951). Bacillus juntamente com o gênero Pseudomonas têm sido considerados agentes de biocontrole de doenças de plantas (Cook et al., 1996), o que demonstra o seu grande potencial para utilização na agricultura. A estirpe de B. cereus, por exemplo, isolada como endófito de planta de mostarda, quando inoculada em mudas de algodão, é capaz de reduzir a incidência da doença de podridão da raiz causada pela Rhizoctonia solani (Pleban et al., 1995). 
Tabela 3 - Gêneros de bactérias endofíticas identificados de diferentes partes da planta de mandioca, na Amazônia.

\begin{tabular}{|c|c|c|}
\hline Gêneros & Tecido vegetal utilizado no isolamento & $\begin{array}{l}\text { Porcentual (\%) em relação ao número } \\
\text { total de Bactérias endofíticas identificadas }\end{array}$ \\
\hline & Folha & \\
\hline \multirow[t]{3}{*}{ Bacillus } & Maniva & 32,4 \\
\hline & Raiz & \\
\hline & Folha & \\
\hline \multirow[t]{4}{*}{ Enterobacter } & Maniva & 10,8 \\
\hline & Raiz & \\
\hline & Folha & \\
\hline & Maniva & \\
\hline \multirow[t]{3}{*}{ Stenotrophomonas } & Raiz & 8,11 \\
\hline & Raiz & \\
\hline & Raiz & \\
\hline Pseudomonas & Folha & 2,7 \\
\hline Microbacterium & Folha & 2,7 \\
\hline Brachybacterium & Maniva & 2,7 \\
\hline Curtobacterium & Folha & 2,7 \\
\hline Ralstonia & Raiz & 3,22 \\
\hline Burkholderia & Raiz & 8,10 \\
\hline kluyvera & Maniva & 2,7 \\
\hline Salmonella & Maniva & 5,4 \\
\hline Klebsiella & Raiz & 2,7 \\
\hline Clavibacter & Folha & 2,7 \\
\hline Streotomyces & Raiz & 2,7 \\
\hline Acidovorax & Raiz & 2,7 \\
\hline
\end{tabular}

As bactérias endofíticas são conhecidas pelo seu enorme potencial para utilização em programas de controle biológico. Conforme apresentado na tabela acima, o gênero Bacillus apresentou um grande porcentual (\%) em relação ao número total de bactérias endofíticas identificados, de colonização nas três partes da planta. Este gênero possui um grande potencial antagônico contra fitopatógenos de planta de mandioca, onde se pode comprovar através de testes de antagonismo.

\subsection{Teste de antagonismo}

Resultados de ensaios realizados em condições de laboratório mostraram que a produção de metabólitos antifúngicos pelas bactérias endofíticas de mandioca frente ao Pythium aphanidermatum apresentaram valores significativos (Tabela 4), onde as melhores linhagens foram escolhidas para uma posterior análise contra outros dois fitopatógenos, Rhizoctonia solani 
e Sclerotium rolfsii. A melhor linhagem isolada de mandioca que apresentou um potencial de biocontrole pelo método em Plaqueamento de Petri com meio agarizado foi o Bacillus pumilus, MAIIIM4a, o qual apresentou um alto percentual de inibição de 54,2\% comparando com o controle, caracterizando assim uma linhagem excelente para melhores estudos.

Tabela 4 - Triagem das bactérias pelo teste de antagonismo frente ao patógeno Pythium aphanidermatum.

\begin{tabular}{|c|c|c|c|}
\hline Bactérias endofíticas de mandioca & $\begin{array}{c}P . a \\
\text { (\% inibição) }\end{array}$ & Bactérias endofíticas de mandioca & $\begin{array}{c}\text { P.a } \\
\text { (\% inibição) }\end{array}$ \\
\hline $\begin{array}{l}\text { MAIF1b } \\
\text { B.pumilus }\end{array}$ & - & $\begin{array}{c}\text { MAIIIR4b } \\
\text { Klebsiella pnumoniae-GC-subgrupo B }\end{array}$ & - \\
\hline $\begin{array}{c}\text { MAIVR1f } \\
\text { Pseudomonas rhodeseae }\end{array}$ & - & $\begin{array}{c}\text { MAIF2b } \\
\text { B. cereus-GC-Subgrupo A }\end{array}$ & - \\
\hline $\begin{array}{c}\text { MAIIIR2b } \\
\text { Burkholderia cepacia }\end{array}$ & - & $\begin{array}{c}\text { MAIIIR4b } \\
\text { Klebsiella pnumoniae-GC-subgrupo B }\end{array}$ & - \\
\hline $\begin{array}{c}\text { MAIVR2b } \\
\text { Não identificado } \\
\end{array}$ & $* 26,25$ & $\begin{array}{l}\text { MAIR2a } \\
\text { B. cereus } \\
\end{array}$ & - \\
\hline $\begin{array}{c}\text { MAIVM2a } \\
\text { Enterobacter cancerogenus }\end{array}$ & $* * 32,5$ & $\begin{array}{l}\text { MAIIIR3a Bradyrhizobium japonicum -GC- } \\
\text { Subgrupo A }\end{array}$ & $* * 35$ \\
\hline $\begin{array}{c}\text { MAIF1a } \\
\text { Microbacterium aerborescens }\end{array}$ & - & $\begin{array}{c}\text { MAIIIR4a } \\
\text { Enterobacter aerogenes }\end{array}$ & - \\
\hline $\begin{array}{l}\text { MAIIIR1b } \\
\text { B. cereus }\end{array}$ & - & $\begin{array}{c}\text { MAIF3b } \\
\text { Curtobacterium luteum }\end{array}$ & - \\
\hline $\begin{array}{c}\text { MAIVR1b } \\
\text { B. cereus-GC-Subgrupo A }\end{array}$ & - & $\begin{array}{c}\text { MAIR1b } \\
\text { B. cereus-GC-Subgrupo A }\end{array}$ & \\
\hline $\begin{array}{l}\text { MAIVM3a } \\
\text { B. antracis }\end{array}$ & $* 26,25$ & $\begin{array}{c}\text { MAIIIF1a } \\
\text { Stenotrophomonas maltophilia }\end{array}$ & \\
\hline $\begin{array}{c}\text { MAIIIR3b } \\
\text { Stenotrophomonas maltophilia }\end{array}$ & - & $\begin{array}{c}\text { MAIIIM4a } \\
\text { Bacillus pumilus }-G C-\text { Subgrupo B }\end{array}$ & $* * * 54,2 \%$ \\
\hline $\begin{array}{r}\text { MAIR2b } \\
\text { B. cereus } \\
\end{array}$ & - & $\begin{array}{c}\text { MAIF4b } \\
\text { B. cereus-GC-Subgrupo A }\end{array}$ & $* * 32,5$ \\
\hline $\begin{array}{c}\text { MAIIM2b } \\
\text { Salmonella bongori }\end{array}$ & - & $\begin{array}{c}\text { MAIF6b } \\
\text { Clavibacter michiganensis isidiosum }\end{array}$ & $* * 33,75$ \\
\hline $\begin{array}{c}\text { MAIMЗа } \\
\text { Brevibacillus brevi }\end{array}$ & - & $\begin{array}{c}\text { MAIVM2b } \\
\text { Salmonella choleraesius }\end{array}$ & - \\
\hline $\begin{array}{c}\text { MAIIIM2b } \\
\text { B. antracis } \\
\end{array}$ & $* * * 47,9 \%$ & $\begin{array}{c}\text { MAIR1b } \\
\text { B. cereus-GC-Subgrupo A }\end{array}$ & - \\
\hline $\begin{array}{c}\text { MAIIIR1f } \\
\text { Enterobacter cloacae }\end{array}$ & - & $\begin{array}{c}\text { MAIVM1b } \\
\text { B. cereus } \\
\end{array}$ & $* * * 51 \%$ \\
\hline $\begin{array}{c}\text { MAIIIR2a } \\
\text { Stenotrophomonas maltophilia }\end{array}$ & - & $\begin{array}{c}\text { MAIIM2b } \\
\text { Salmonella bongori }\end{array}$ & - \\
\hline $\begin{array}{c}\text { MAIIR2b } \\
\text { Kluyvera cryocrescens }\end{array}$ & - & $\begin{array}{c}\text { MAIVR3b } \\
\text { Burkholderia cepacia }\end{array}$ & **35 \\
\hline $\begin{array}{c}\text { MAIIR2b } \\
\text { Kluyvera cryocrescens } \\
\end{array}$ & $* 28,75$ & $\begin{array}{c}\text { MAIR2f } \\
\text { Burkholderia cepacia-GC-Subgrupo B }\end{array}$ & - \\
\hline $\begin{array}{c}\text { MAIIIM1a } \\
\text { Salmonella enteritidis }\end{array}$ & - & $\begin{array}{l}\text { MAIIIMIb } \\
\text { Não identificado }\end{array}$ & $* * 36,25$ \\
\hline $\begin{array}{c}\text { MAIIIM2a } \\
\text { Enterobacter aerogenes }\end{array}$ & - & $\begin{array}{c}\text { MAIIR1a } \\
\text { B. cereus-GC-Subgrupo A }\end{array}$ & - \\
\hline $\begin{array}{c}\text { MAIVR2a } \\
\text { Streptomyces olivaceus }\end{array}$ & - & $\begin{array}{c}\text { MAIM1b } \\
\text { Brachybacterium paraconglomeratum }\end{array}$ & - \\
\hline $\begin{array}{c}\text { MAIF2b } \\
\text { B. cereus-GC-Subgrupo A }\end{array}$ & - & $\begin{array}{c}\text { MAIM1a } \\
\text { Gastonia sp. }\end{array}$ & - \\
\hline
\end{tabular}


Desta avaliação 3 bactérias endofíticas apresentaram melhor atividade antagônica frente aos fungos fitopatogênicos $R$. solani , Pythium e Sclerotium rolfsii em meio BDA, ou seja, estas bactérias estudadas foram capazes de inibir o crescimento miceliano (Tabela 5).

Tabela 5 - Inibição do crescimento miceliano de fungos fitopatogênicos por bactéria endofíticas, isoladas de mandioca.

\begin{tabular}{cccc}
\hline Bactérias selecionadas & $\begin{array}{c}\text { Halo de inibição } \\
\text { Rhizoctonia solani }\end{array}$ & $\begin{array}{c}\text { Halo de inibição } \\
\text { Pythium }\end{array}$ & $\begin{array}{c}\text { Halo de inibição } \\
\text { Sclerotium rolfsii }\end{array}$ \\
\hline $\begin{array}{c}\text { MAIIIM4a }- \\
\text { Bacillus pumilus }\end{array}$ & $46,9 \%$ & $\mathbf{5 4 , 2 \%}$ & $51,6 \%$ \\
\hline $\begin{array}{c}\text { MAIIIM2b } \\
\text { Bacillus antracis }\end{array}$ & $43,7 \%$ & $\mathbf{4 7 , 9 \%}$ & $37,5 \%$ \\
\hline $\begin{array}{c}\text { MAIVM1b } \\
\text { Bacillus cereus }\end{array}$ & $41,7 \%$ & $\mathbf{5 1 \%}$ & $35,7 \%$ \\
\hline
\end{tabular}

Bactéria do gênero Bacillus produz vários antibióticos e alguns com atividades antifúngicas (Katz \& Demain, 1977, Koryzybski et al., 1978).

\subsection{Cinética de crescimento da bactéria B. pumilus}

\subsubsection{Produção de biomassa de B. pumilus em diferentes meios de cultura.}

A curva de crescimento, (Fig. 11), representa uma situação próxima da real quando se cultiva a bactéria $B$. pumilus em um meio de cultura rico e sob condições aeróbicas.

A partir dos resultados que mostraram a forte inibição desta bactéria frente aos fitopatógenos, decidiu-se estudar a biomassa da bactéria MAIIIM4a (Bacillus pumilus) em diferentes meios de cultura, a fim de avaliar o melhor meio de cultura que a bactéria necessita para crescer e posteriormente produzir seus metabólitos secundários. Os resultados estão descritos nas Figuras 12, 13, 14, 15 e 16.

Nesta análise pôde-se observar que os 4 meios de cultura apresentaram crescimento com tempo de 6 a 24 hs, com exceção do meio CN, os outros meios foram semelhantes para o crescimento. Os meios de cultura TS, CN E BD apresentaram contaminação, já o meio KB apresentou resultado bom e esperado. 


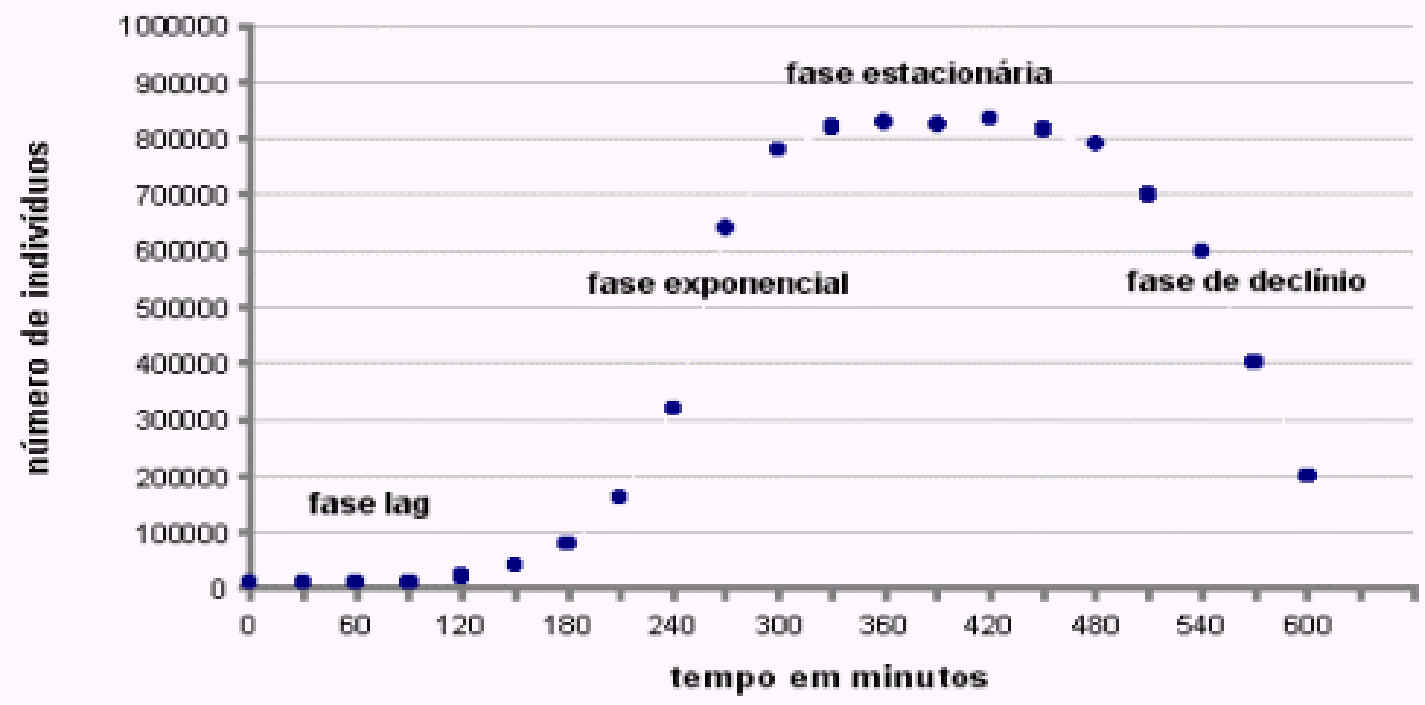

Figura 11 - Padrão típico de crescimento de uma cultura bacteriana em sistema fechado

O crescimento de uma cultura bacteriana pôde ser monitorado através da estimativa do aumento da biomassa total em determinados intervalos de tempo. O aumento da biomassa total de uma cultura bacteriana em crescimento em meio líquido pode ser monitorado por medidas da densidade óptica da cultura. Alíquotas da cultura em crescimento são retiradas em determinados intervalos de tempo e mede-se a absorbância da cultura contra um comprimento de onda de $600 \mathrm{~nm}$ (cor laranja). Para tal utiliza-se um espectrofotômetro "zerado" com meio de cultura isento de inóculo que é denominado "branco".

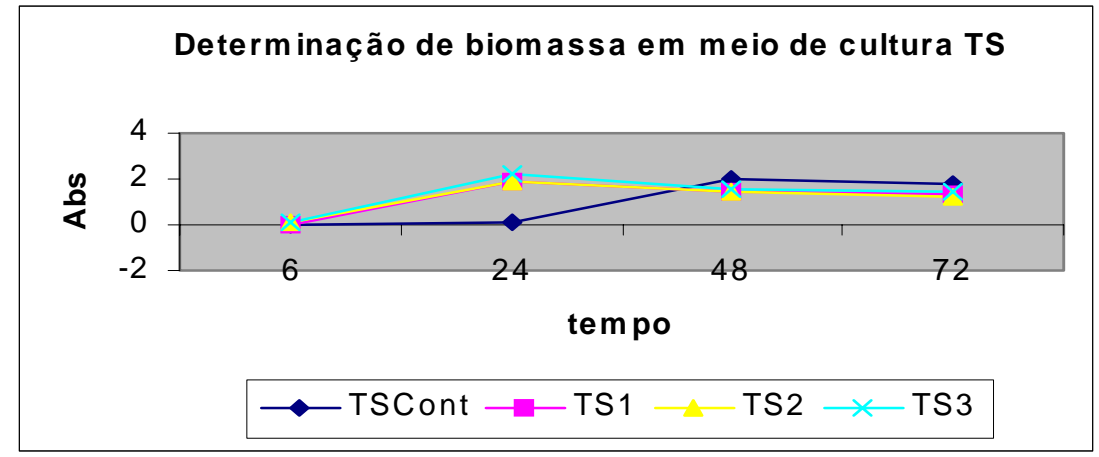

Figura 12 - Biomassa em meio de cultura TS em diferentes tempos de incubação 


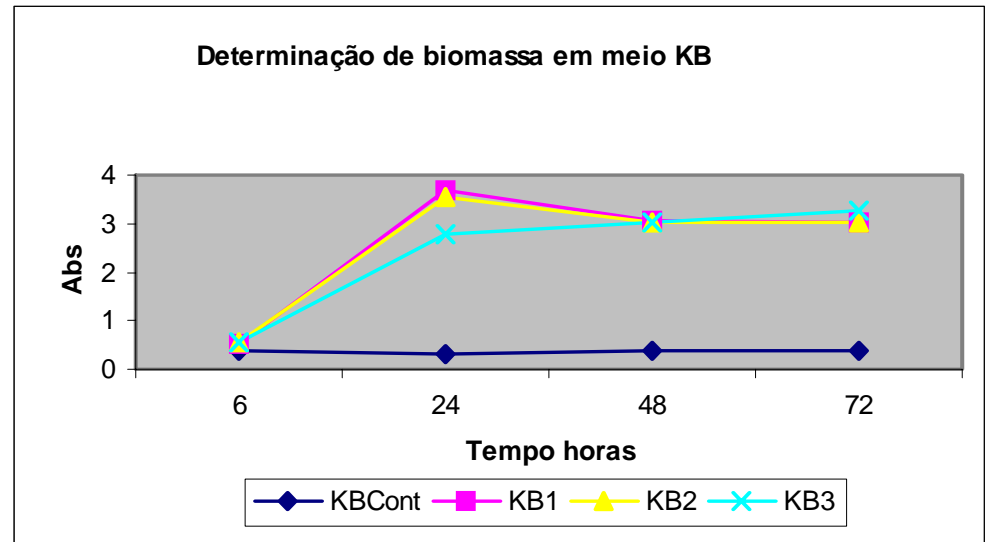

Figura 13 - Biomassa em meio de cultura KB em diferentes tempos de incubação

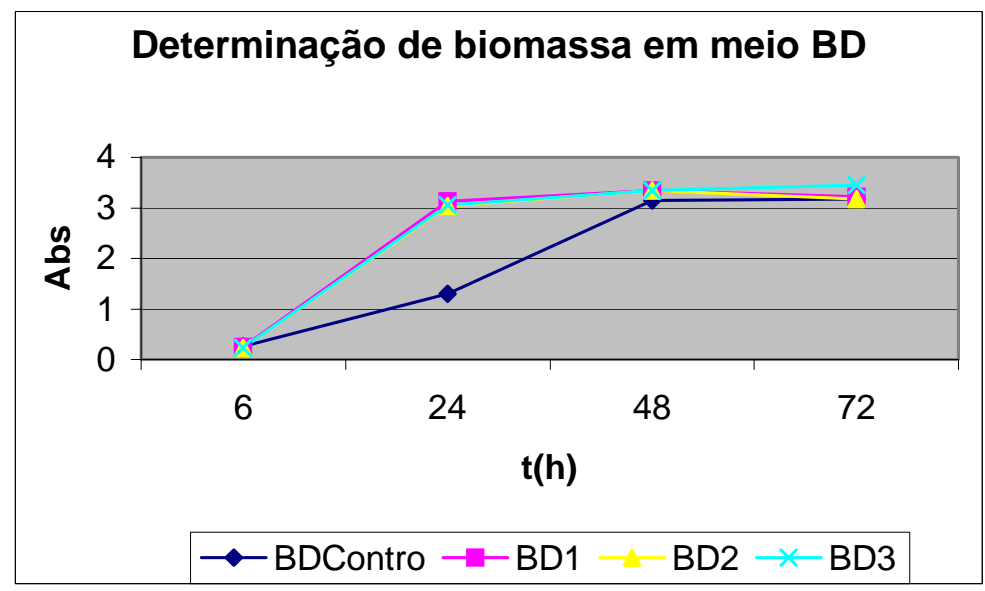

Figura 14 - Biomassa em meio de cultura BD em diferentes tempos de incubação 


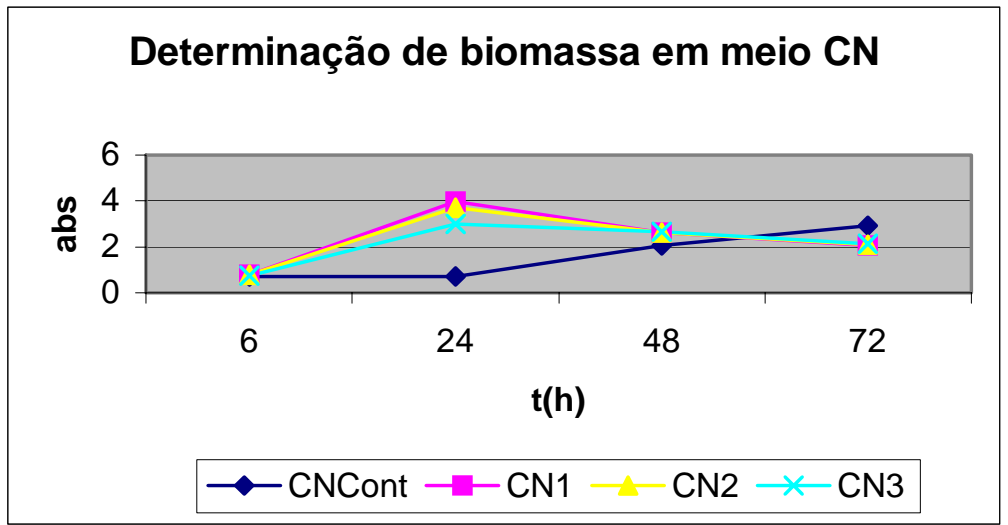

Figura 15- Biomassa em meio de cultura $\mathrm{CN}$ em diferentes tempos de incubação.

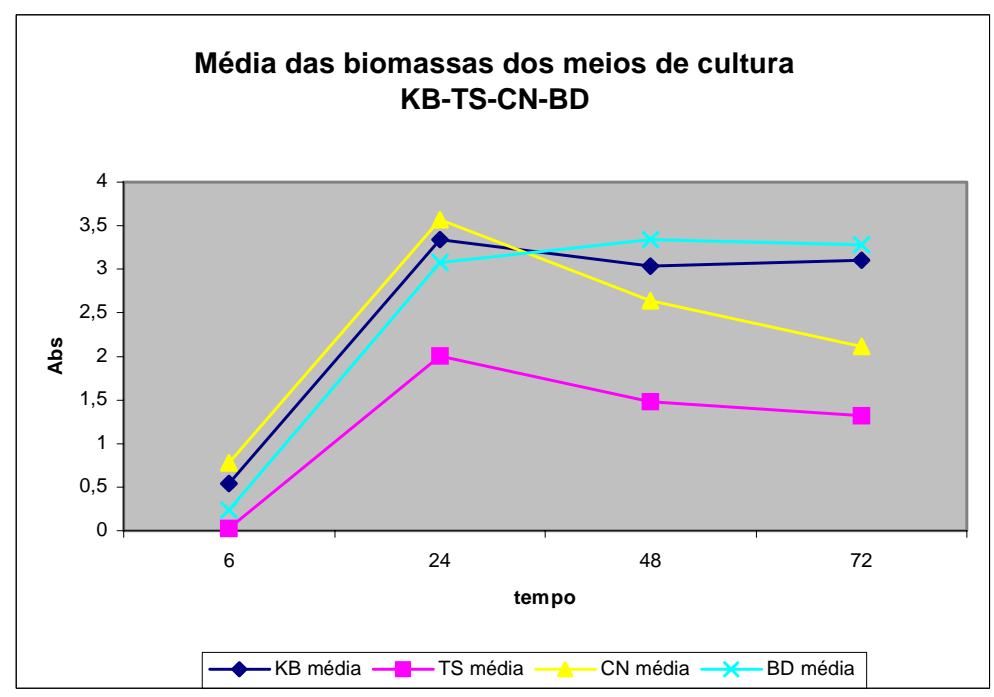

Figura 16 - Biomassa de todos os meios de cultura, TS, CN, BD e KB em diferentes tempos de incubação. 


\subsection{Extração de metabólitos secundários de B. pumilus, MAIIIM4a.}

Para este estudo os resultados apresentados na Figura 17 mostram a capacidade dos solventes escolhidos (hexano, diclorometano e acetato de etila) de extraírem os metabólitos antifúngicos. O hexano é um solvente alifático, apresentando hidrocarbonetos isômeros com 6 átomos de carbono. É um líquido incolor com odor característico insolúvel em água. Uma das características principais deste produto é possuir alto poder extrativo e rápida evaporação é considerado na escala de polaridade como apolar e tendo a capacidade de extrair compostos como ácidos graxos e outros compostos afins, a amostra extraída com este solvente não apresentou atividade antifúngica quando comparado com o controle.

O diclorometano é um líquido incolor, muito volátil, de odor etéreo geralmente perceptível entre 200 e 300 ppm. É pouco solúvel na água (1,32 g em 100 g de água a $20^{\circ} \mathrm{C}$ ) embora miscível com a maioria dos solventes orgânicos. Por outro lado, o diclorometano dissolve um grande número de substâncias tais como as gorduras, óleos e resinas e foi um bom solvente para extrair compostos antifúngicos da amostra, pois através do teste de antibiose observou-se uma boa formação do halo de inibição contra os fitopatógenos. Acetato de etila é um bom solvente, dissolve um grande número de substâncias tais como as gorduras, óleos e resinas e foi o solvente que apresentou melhor resultado no teste de antibiose, pois este conseguiu extrair com maior eficiência compostos antifúngicos frente aos 3 fitopatógenos (Tabela 6).

Os solventes acetato de etila e dicolorometano apresentaram resultados semelhantes devido às polaridades serem próximas, já o hexano não apresentou eficiência no resultado.

Com as extrações dos meios de cultura com os diferentes solventes determinou-se qualitativamente a habilidade dos metabólitos extraídos de inibir o crescimento miceliano de várias espécies de Rhizoctonia solani, Pythium aphanidermatum e Sclerotium rolfsii. 
Tabela 6 - Avaliação da atividade dos diferentes extratos de B. pumilus sobre os fungos fitopatogênicos R.. solani, P. aphanidermatum e S. rolfsii.

\begin{tabular}{cccc}
\hline Extratos & R. solani & P. aphanidermatum & S. rolfsii \\
\hline EB-1(hexano) & - & + & - \\
EB-2 (diclorometano) & +++ & ++ & ++ \\
EB-3 (acetato de etila) & +++ & ++ & ++ \\
\hline
\end{tabular}

- = Inativo; + = Ativo, ++ = Muito Ativo

Como pode ser observado na tabela 6, os extratos em diclorometano (EB-2) e em acetato de etila (EB-3) apresentaram uma forte atividade contra as linhagens fitopatogênicas dos fungos $P$. aphanidermatum e S. rolfsii, e o extrato hexânico (EB-1) apresentou atividade fraca contra o fungo $P$. aphanidermatum. Esses resultados positivos incentivaram o estudo dos compostos químicos dos respectivos extratos, comparando-os entre si.

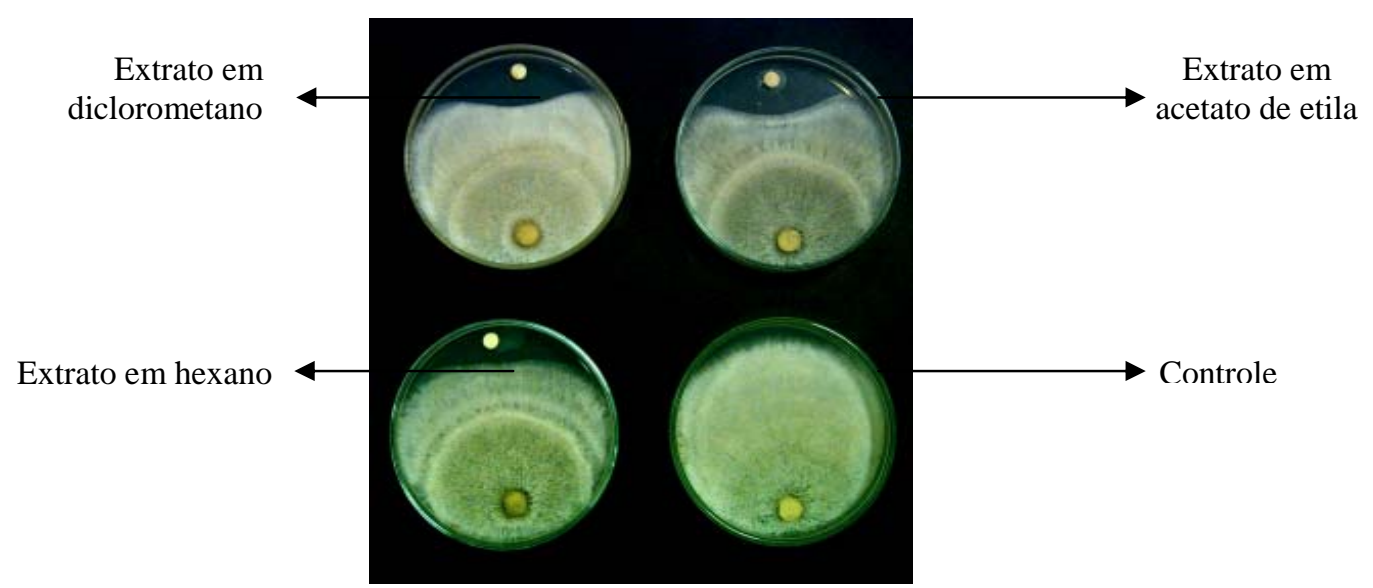

Figura 17 - Teste de antibiose frente ao fitopatógeno P. aphanidermatum com os extratos em diclorometano, em acetato de etlia, em hexano e o controle respectivamente.

5.7 Estudos dos metabólitos secundários produzidos por Bacillus pumilus, MAIIIM4a por diferentes métodos de análise.

\subsubsection{Cromatografia em camada Delgada (CCD)}

Os extratos foram submetidos a um minucioso estudo por cromatografia em camada delgada (CCD) com diferentes sistemas de solventes, na tentativa de otimização na separação dos compostos presentes. Em função de todas estas interações entre 
amostra/fase móvel/fase estacionária, o sistema foi otimizado para cada amostra. Dos ensaios realizados em CCD os solventes que apresentaram melhor resolução foi a mistura de eluentes diclorometano/ acetato de etila (9:1). Na técnica de CCD pôde-se constatar a presença no extrato em hexano de 2 "spots"; no extrato em diclorometano de 6 “spots" diferentes e no extrato em acetato de etila de 10 "spots”, todas visíveis sob lâmpada UV nos comprimentos de onda a 254 nm e 366 nm e reveladas com dois tipos de reveladores químicos - anisaldeído e ácido fosfomolibdico - que resultaram em manchas muito intensas, indicando a alta concentração da substância detectada (Figura 18). Os "spots" dos respectivos extratos foram visualizadas e suas distâncias de migração calculadas (Tabela 7).

Tabela 7 - Rfs das frações dos extratos visualizadas sob lâmpada UV com dois comprimentos de onda 254/366 nm.

\begin{tabular}{ccccccccccc} 
Extratos & Rf 1 & Rf 2 & Rf 3 & Rf4 & Rf 5 & Rf 6 & Rf7 & Rf 8 & Rf 9 & Rf 10 \\
\hline Controle & 0,89 & 0,618 & 0,527 & 0,230 & & & & & & \\
\hline EB-1 & 0,327 & 0,236 & & & & & & & & \\
\hline EB-2 & 0,89 & 0,80 & 0,654 & 0,6 & 0,527 & 0,234 & & & & \\
\hline EB-3 & 0,89 & 0,781 & 0,709 & 0,672 & 0,618 & 0,563 & 0,49 & 0,418 & 0,29 & 0,254
\end{tabular}

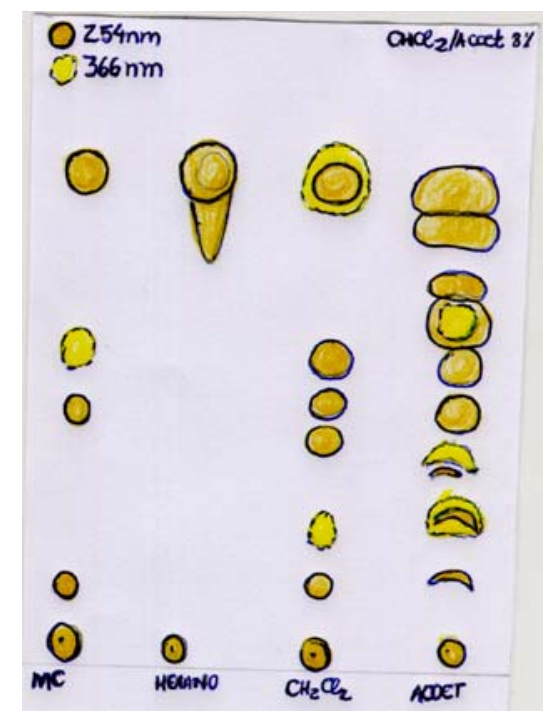

Figura 18 - Cromatografia em camada delgada utilizando os diferentes extratos da bactéria e também o controle, placa visualizada em câmara de UV com dois comprimentos de ondas (254/366 nm). 


\subsubsection{Bioautografia}

Após a realização da técnica de CCD realizou-se a bioautografia, onde foram utilizados 3 fungos testes para que se observasse o halo de inibição sobre o composto visualizado na placa de cromatografia. Através de biomonitoramento com o fungo, verificou-se que as 3 frações mais apolares apresentaram atividade. Os extratos aplicados na placa obtiveram os seguintes resultados (Tabela 8).

Tabela 8 - Resultados dos testes de bioautografia com os extratos da bactéria MAIIIM4a que apresentaram atividade antifúngica.

\begin{tabular}{llll}
\hline Extratos & Fusarium moniliforme & Fusarium oxysporium & Aspergillus niger \\
\hline${ }^{*}$ EB-1 & - & - & + \\
\hline${ }^{*}$ EB-2 & + & + & + \\
\hline${ }^{*}$ EB-3 & + & + & + \\
\hline
\end{tabular}

EB-1 Extraído com hexano; EB2- Extraído com diclorometano; EB3- Extraído com acetato de etila

A bioautografia foi considerada um ensaio eficiente e sensível na determinação da atividade antimicrobiana, pois menos de 2,5 $\mu$ g de substância utilizada foi suficiente para a formação do halo de inibição, pois as frações hexânica, diclorometânica e acetato de etila apresentaram resultados positivos para Aspergillus niger e as frações em diclorometano e acetato de etila apresentaram resultados positivos ao Fusarium moniliforme e Fusarium oxysporium em bioautografia.

Os dados apresentados não estabelecem a natureza dos compostos responsáveis pela ação antifúngica, porém estudos realizados com esta bactéria demonstram que a mesma é rica em compostos fenólicos e óleos fixos, substâncias que podem ser responsáveis pela ação verificada. As 3 frações ativas contra os fungos-teste na técnica de bioautografia foram analisadas novamente no teste de antibiose e não apresentaram atividade frente ao Pythium aphanidermatum, Rhizoctonia solani e Sclerotium rolfsii, o que leva acreditar que exista uma sinergia entre os compostos. O objetivo desta técnica foi identificar a fração que era responsável pela ação antimicrobiana. 


\subsubsection{Cromatografia em coluna}

O extrato em acetato de etila foi fracionado em coluna de SEPHADEX-LH 20 (polímero gelatinoso), usando metanol, diclorometano e acetona como eluentes. Das cinqüenta frações obtidas, fez-se cromatografia em camada delgada e estas foram agrupadas de acordo com a semelhança das frações; destas frações 4 apresentaram compostos diferentes quando visualizadas em câmara UV e quando reveladas .

Portanto, quanto maior for a diferença entre os coeficientes de adsorção, mais completa será a separação do composto (terá maior grau de pureza). Esta separação dos componentes de uma mistura é devido às diferenças nas forças de adsorção entre eles e o adsorvente. Esta técnica não apresentou eficiência nos resultados estes, verificados no teste de antibiose com os fitopatógenos testes.

\subsubsection{Cromatografia gasosa acoplada ao espectrômetro de massas}

Os resultados obtidos pela técnica de cromatografia gasosa acoplada ao espectrômetro de massas estão representadas nas Tabelas 9, 10 e 11.

As análises por CG-EM do extrato de acetato de etila, diclorometano, hexano e controle foram realizadas uma vez que através desta técnica utilizada para a separação e quantificação de produtos diversos, são também usadas como técnica de identificação, em casos especiais, principalmente quando acoplada a um espectrômetro de massas ou outro detector qualitativo.

A identificação dos metabólitos presentes nos extratos foi feita por CG-EM através da comparação de seus espectros de massa com dados da biblioteca Nist 12 e Wiley. Também procedeu - se o estudo dos compostos do meio de cultura sem a bactéria a qual serviu como controle para as análises obtidas. Para serem analisados por CG-EM os extratos EB-1, EB2 e EB-3 foram previamente metilados com Diazometano.

A espécie Bacillus pumilus estudada neste trabalho foi eficiente na produção de metabólitos secundários quando crescidos em meio de cultura líquido Batata Dextrose (BD). Geralmente o meio BD estimula a grande produção de metabólitos comparados com outros meios estudados como, TSB. 
Tabela 9 - Substâncias identificadas no extrato hexânico utilizando CG/EM

\begin{tabular}{cccc}
\hline $\mathbf{N}^{\circ}$ de picos da amostra & Tempo de Retenção & Porcentagem Relativa (\%) & Atribuição \\
\hline 1 & 3,663 & 1,16 & MC \\
\hline 2 & 4,147 & 4,51 & MC \\
\hline 3 & 4,183 & 1,85 & $\begin{array}{c}\text { ACETATO DE N- } \\
\text { PROPILA }\end{array}$ \\
\hline 4 & 5,680 & 26,79 & MC \\
\hline 5 & 13,556 & 2,18 & N-DODECANO \\
\hline 6 & 15,480 & 5,10 & N-TRIDECANO \\
\hline 7 & 17,298 & 24,15 & N-TETRADECANO \\
\hline 8 & 18,372 & 2,96 & NI* \\
\hline 9 & 18,997 & 12,35 & N-PENTADECANO \\
\hline 10 & 20,603 & 12,94 & N-HEXADECANO \\
\hline 11 & 22,105 & 3,19 & N-HEPTADECANO \\
\hline 12 & 22,201 & 2,83 & 2,6 DIMETIL \\
\hline
\end{tabular}

NI* - Não identificado

MC* - Compostos presentes no meio de cultura

Com base neste estudo pode-se concluir que o extrato hexânico EB1 da bactéria MAIIIM4a era constituído em sua maioria de hidrocarbonetos de cadeia longa.

Tabela 10 - Substâncias identificadas no extrato diclorometano utilizando CG/EM.

\begin{tabular}{cccc}
\hline $\begin{array}{c}\mathbf{N}^{\circ} \text { de picos da } \\
\text { amostra }\end{array}$ & Tempo de Retenção & $\begin{array}{c}\text { Porcentagem } \\
\text { Relativa (\%) }\end{array}$ & Atribuição \\
\hline 1 & 3,699 & 1,11 & MC \\
\hline 2 & 4,250 & 41,64 & 3-HIDROXI 2-BUTANONA \\
\hline 3 & 4,360 & 0,57 & N * \\
\hline 4 & 5,284 & 25,64 & $N^{*}$ \\
\hline 5 & 5,383 & 1,03 & $N^{*}$ \\
\hline 6 & 5,475 & 0,80 & METILPROPENILCARBINOL \\
\hline 7 & 5,602 & 5,76 & MC \\
\hline 8 & 5,707 & 6,50 & ACETATO DE ISOPROPILA \\
\hline 9 & 5,796 & 2,13 & 2,3BUTANODIONA \\
\hline 10 & 9,089 & 1,78 & MLCONOOXIMA BENZÍLICO \\
\hline 11 & 10,197 & 4,27 & 2,6 DIMETIL MORFOLINA \\
\hline 12 & 12,065 & 1,20 & METILFENILACETATO \\
\hline 13 & 13,155 & 1,13 & DIETIL FTALATO \\
\hline 14 & 20,623 & 3,36 & BUTIL FTALATO \\
\hline 15 & 25,855 & 3,08 &
\end{tabular}

NI* - Não identificado

MC* - Compostos presentes no meio de cultura

Com base neste estudo pode-se concluir que o extrato diclorometânico da bactéria MAIIIM4a era constituído de derivados do ftalato, compostos aromáticos e diferentes classes de compostos oxigenados (ésteres, alcoois, dióis, cetonas e outros). 
Tabela 11 - Substâncias identificadas no extrato acetato de etila utilizando CG/EM.

\begin{tabular}{cccc}
\hline $\mathbf{N}^{\circ}$ de picos da amostra & Tempo de Retenção & $\begin{array}{c}\text { Porcentagem } \\
\text { Relativa (\%) }\end{array}$ & Atribuição \\
\hline 1 & 3,824 & 0,28 & MC \\
\hline 2 & 4,263 & 1,44 & MC \\
\hline 3 & 5,547 & 46,77 & NI \\
\hline 4 & 5,620 & 2,78 & MC \\
\hline 5 & 5,767 & 5,80 & 1- PENTADECENO \\
\hline 6 & 17,163 & 8,32 & 1- HEXADECENO \\
\hline 7 & 20,506 & 10,41 & 1- OCTODECENO \\
\hline 8 & 23,450 & 5,64 & 14 METIL - \\
\hline 9 & 23,789 & 0,81 & PENTADECANOATO \\
\hline 10 & 25,238 & 0,82 & MC \\
\hline 11 & 25,896 & 6,19 & NI* \\
\hline 12 & 26,111 & 3,86 & MC \\
\hline 13 & 26,402 & 4,23 & DIOCTIL FITALATO \\
\hline 14 & 28,546 & 1,02 & \\
\hline 15 & 33,053 & 1,36 & \\
\hline 14 & & & MCIOL \\
\hline
\end{tabular}

NI* - Não identificado

MC* - Compostos presentes no meio de cultura

Com base neste estudo pode-se concluir que o extrato de acetato de etila da bactéria MAIIIM4a era constituído derivados do ftalato, ésteres graxos, hidrocarbonetos insaturados de cadeia longa e dióis.

A técnica de CG/EM forneceu-nos os prováveis componentes presentes nos extratos, de acordo com o tempo de retenção e com a biblioteca do equipamento (Nist 12; Nist 62 e Wiley 139).

\subsubsection{Cromatografia líquida acoplada ao espectrômetro de massas (LC-EM/EM)}

De todas as técnicas cromatográficas utilizadas neste trabalho, esta foi a técnica de melhor eficiência e precisão para se identificar através da fragmentação compostos químicos, entre as mais importantes a PUMILACIDINA, cadeia de ácidos graxos ligadas a uma cadeia peptídica, denominada de metabólito antifúngico. Abaixo segue os espectros de massas obtidos para a pumilacidina, visando sua confirmação. (Figs. 19 a 28). 


\section{Pumilacidina m/z 1051.0 (C16)}

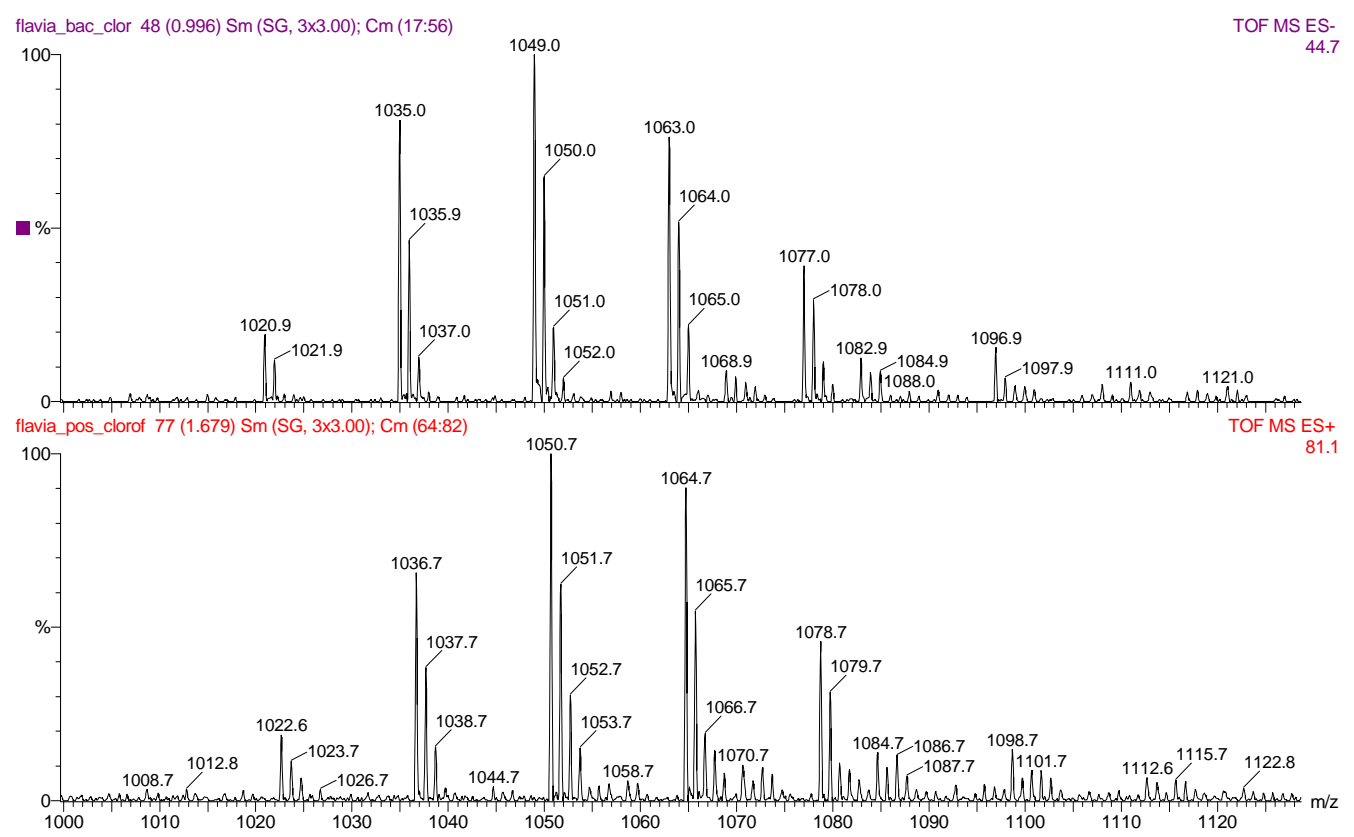

Figura 19 - Espectros de eletrospray (ESI) do pumilacidina: a) modo negativo e b) modo positivo

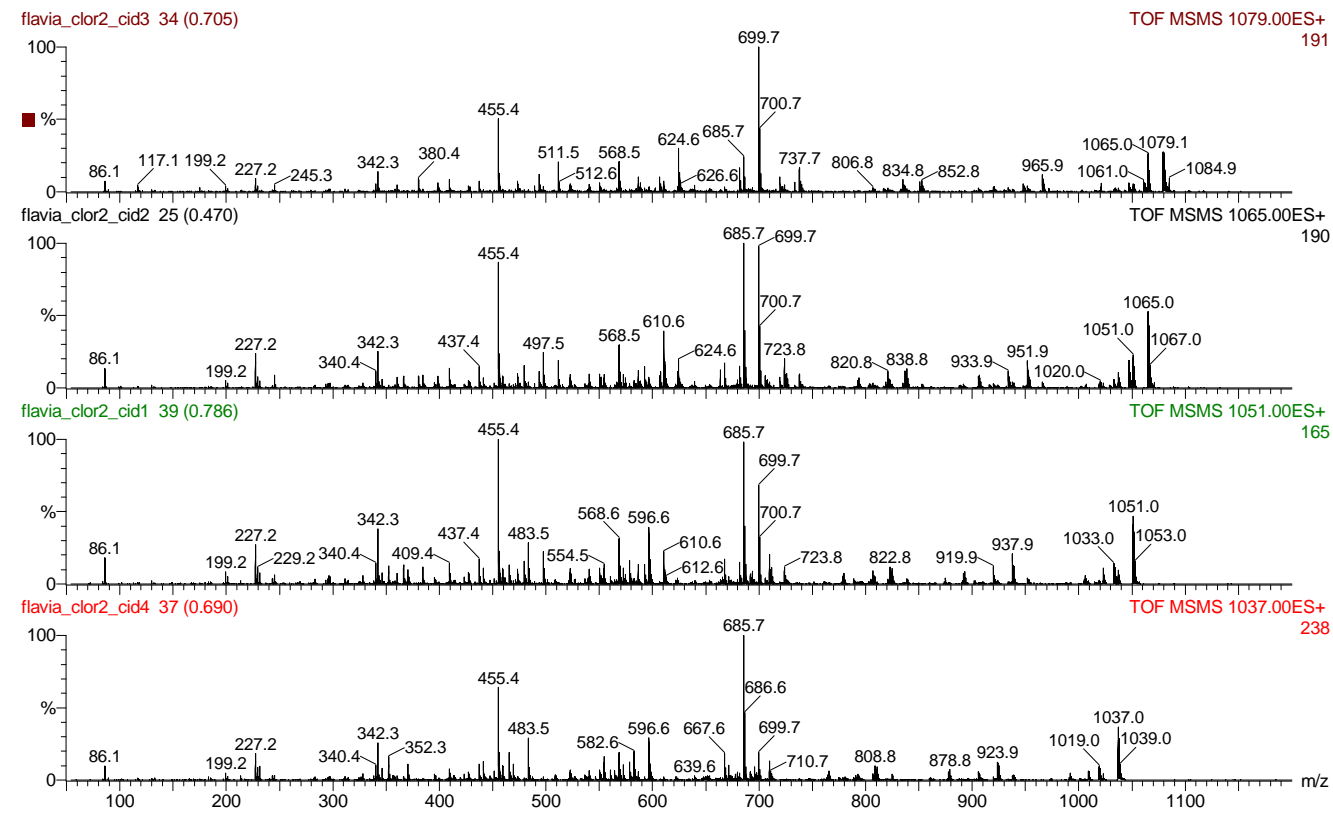

Figura 20 - Espectros MS/MS de fragmentação induzida por colisão (CID) (dos pumilacidina a) CID do composto m/z 1079.1; b) CID do composto m/z 1065.0; c) CID do composto m/z 1051.0 e d) CID do composto m/z 1037.0 
flavia_clor2_cid3 34 (0.705)

TOF MSMS 1079.00ES+

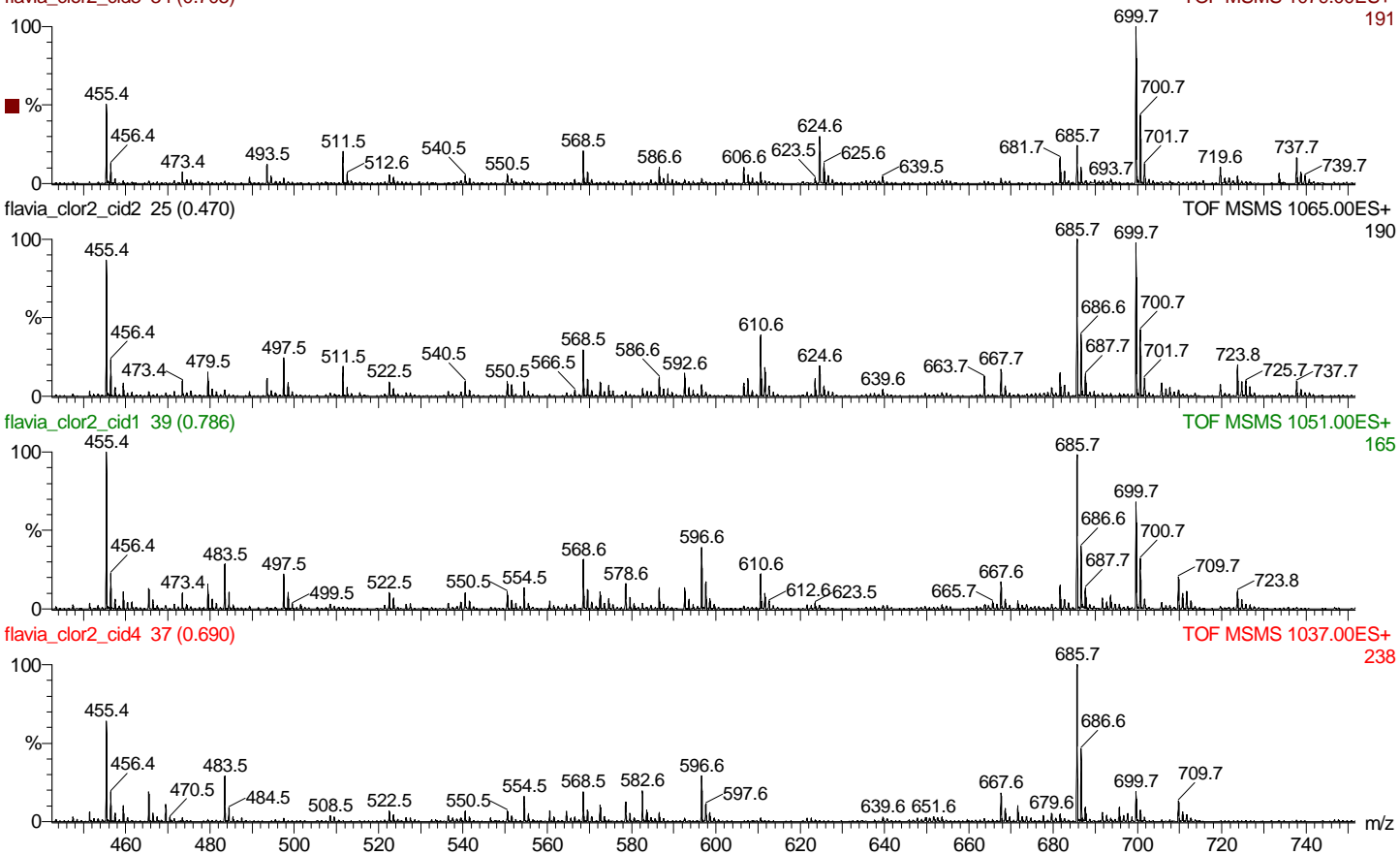

Figura 21 - Expansão dos espectros MS/MS de fragmentação induzida por colisão (CID) dos pumilacidina.

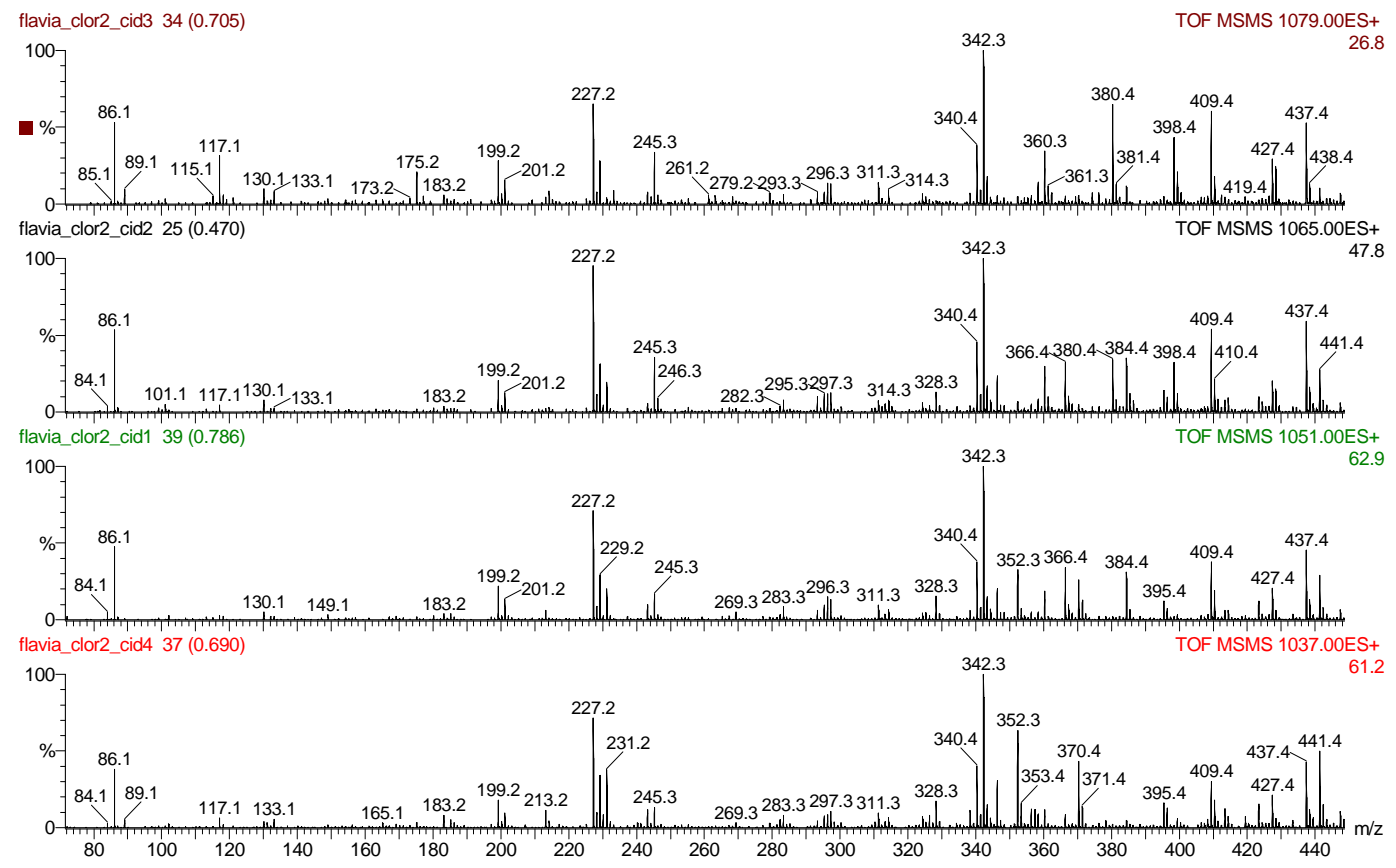

Figura 22 - Expansão dos espectros MS/MS de fragmentação induzida por colisão (CID) dos pumilacidina. 


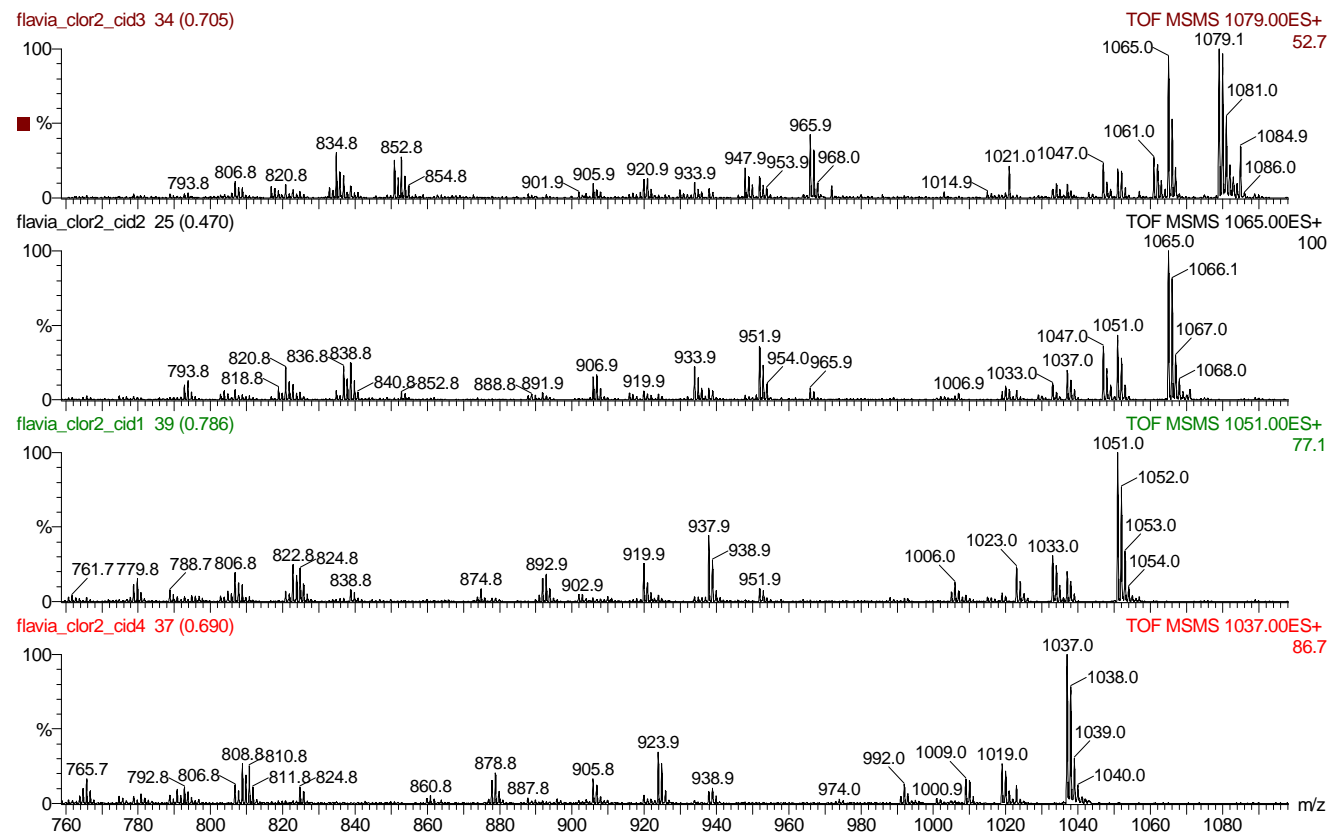

Figura 23 - Expansão dos espectros MS/MS de fragmentação induzida por colisão (CID) dos pumilacidina

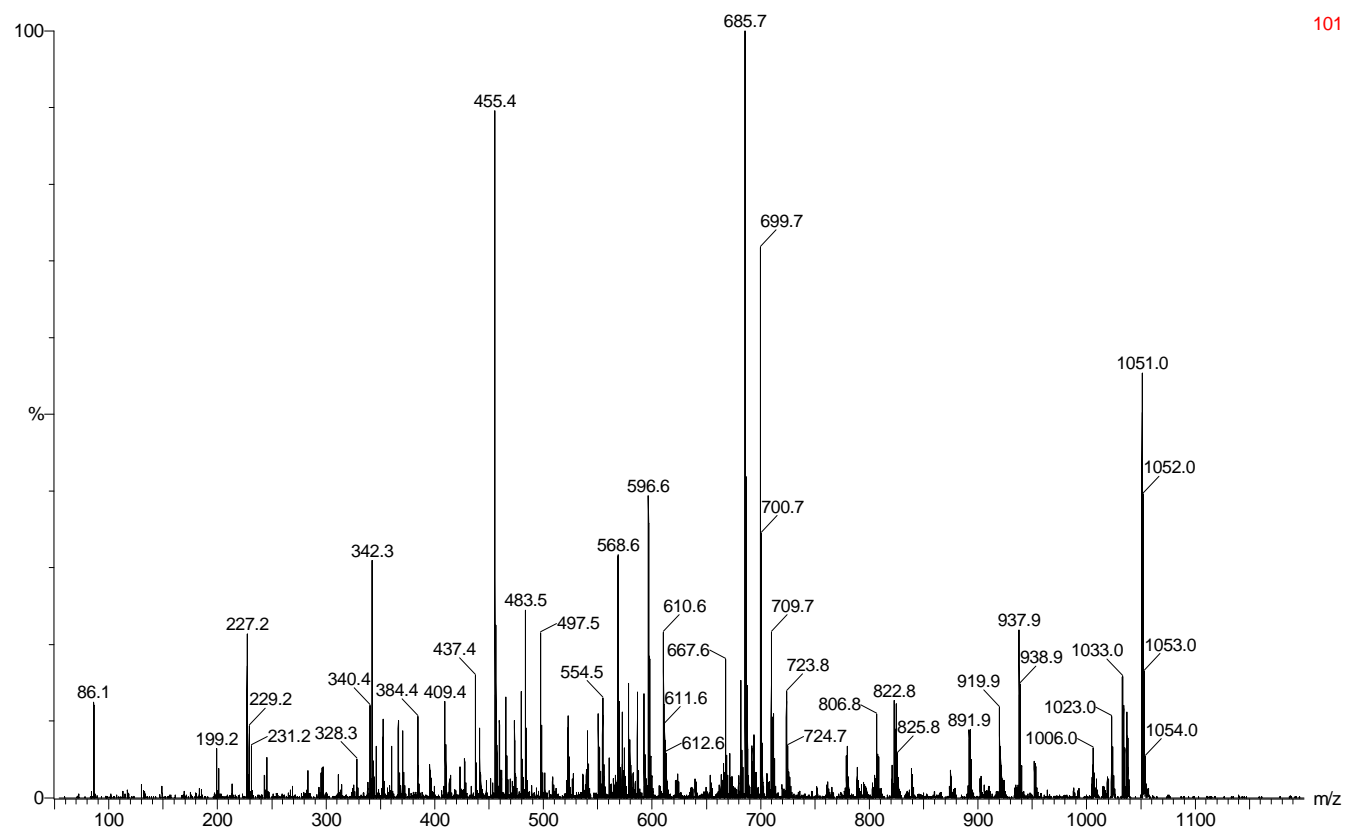

Figura 24 - Expansão dos espectros MS/MS de fragmentação induzida por colisão (CID) dos pumilacidina 


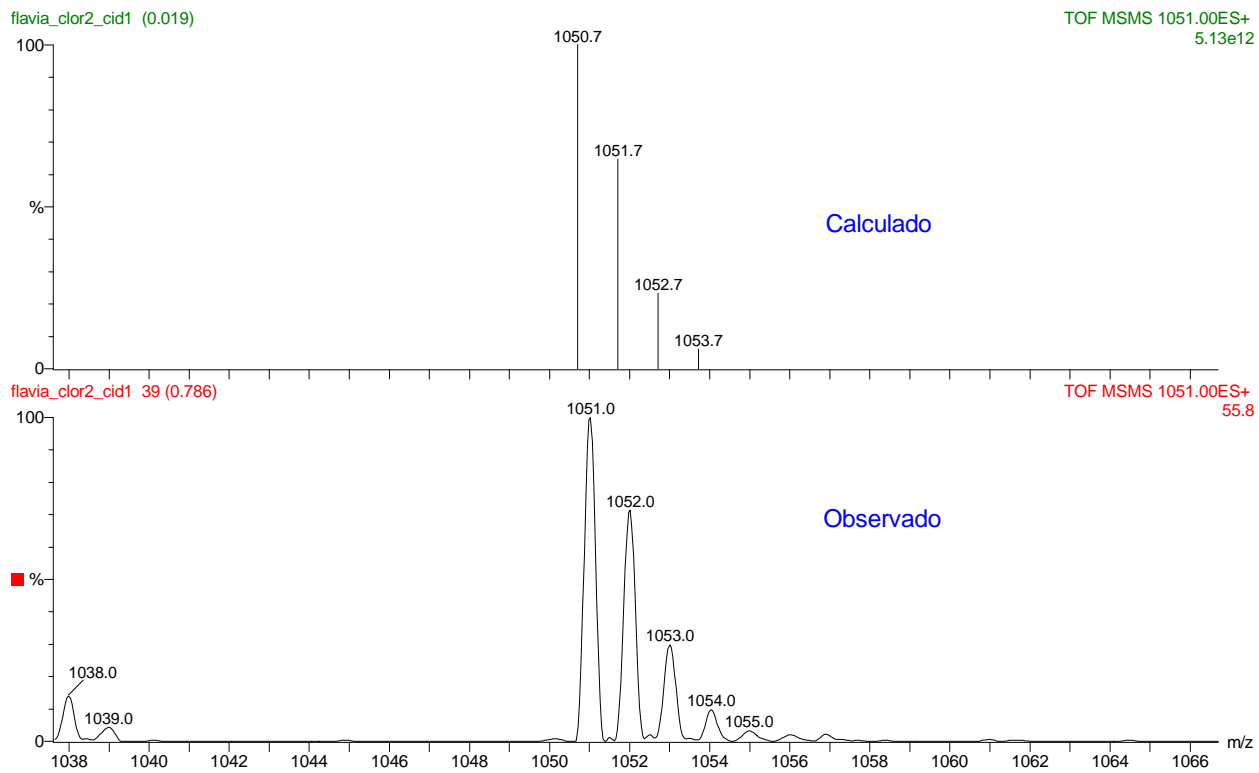

Figura 25 - Valores calculados e observados para o pumilacidina $C_{16}$

Depois de obtido o espectro buscou-se em literaturas específicas a estrutura do composto, pumilacidina. A estrutura pode ser observada nas Figuras 26, 27 e 28.

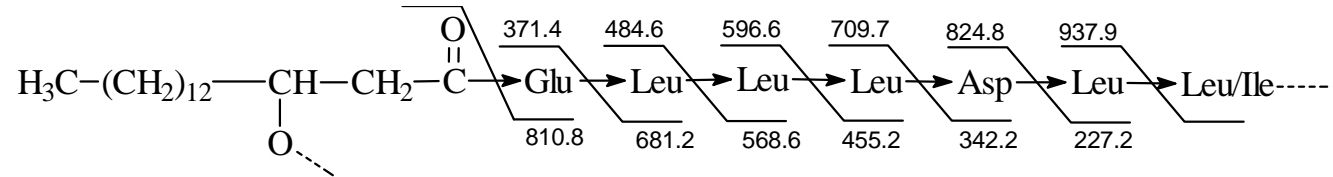

Figura 26 - Seqüência de aminoácidos ligados a uma cadeia de ácidos graxos. Pumilacidina m/z 1051.0 (C16) 


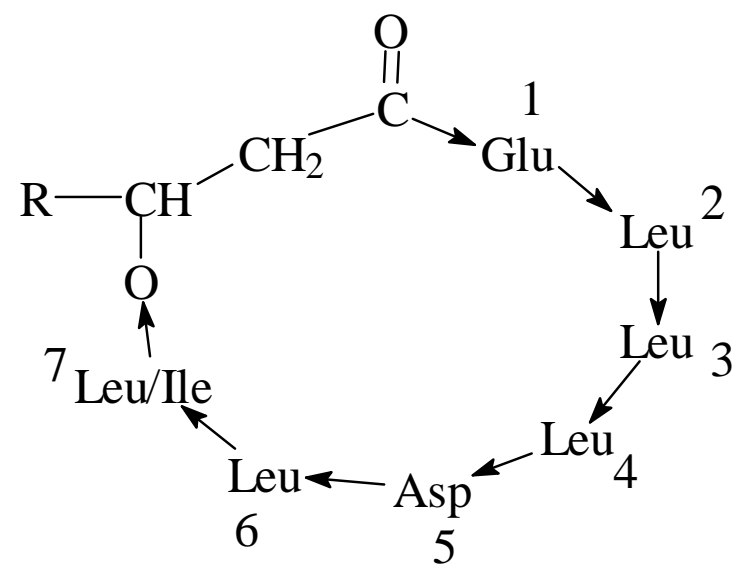

Figura 27 - Pumilacidina, metabólito antifúngico produzido pelo Bacillus pumilus, estrutura cíclica.

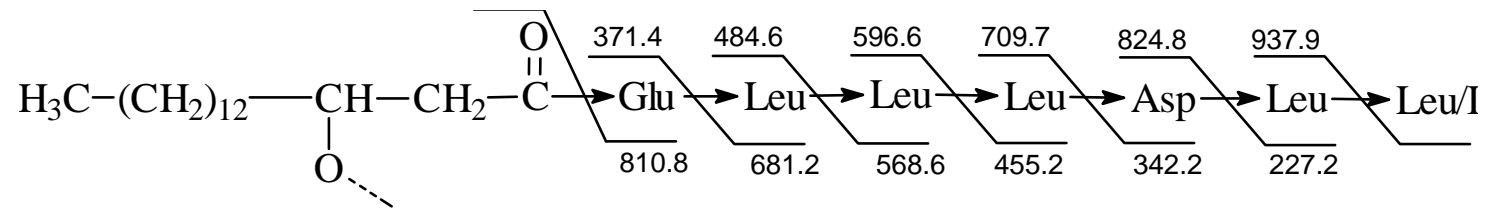

Figura 28 - Caracterização estrutural e sequenciamento dos aminoácidos para o pumilacidina $\mathrm{m} / \mathrm{z} 1051.0$

\subsection{Obtenção de mutantes da bactéria $B$. pumilus resistentes a antibióticos}

A bactéria endofítica Bacillus pumilus foi resistente ao antibiótico Eritromicina na concentração de 50 ppm, supondo-se que a bactéria foi capaz de produzir quantidades suficientes de uma enzima que destrói ou modifica a estrutura do antibiótico. O antibiótico, eritromicina $50 \mathrm{ppm}$, foi incapaz de penetrar na superfície das células bacterianas; a bactéria assumiu uma via bioquímica alternativa que desvia a reação particular inibida pelo antibiótico e a bactéria possui componentes celulares não afetados pelos antibióticos (Tabela 12). 
Tabela 12 - Resistência da bactéria MAIIIM4a, a diferentes concentrações de antibióticos.

\begin{tabular}{cccc}
\hline Antibióticos testados & $\mathbf{5 0} \mathbf{p p m}$ & $\mathbf{1 0 0} \mathbf{~ p p m}$ & $\mathbf{1 5 0} \mathbf{~ p p m}$ \\
Ácido Nalidíxico & - & - & - \\
Rifampicina & - & - & - \\
Tetraciclina & - & - & - \\
Eritromicina & $*$ & - & - \\
Penicilina & - & - & -
\end{tabular}

- Sensível

* Resistente

Estes mutantes resistentes a eritromicina também foram avaliados quanto ao potencial inibitório contra o Pythiun e quanto à colonização na planta de mandioca.

\subsection{Colonização de B. pumilus em raízes, manivas, e folhas da mandioca in vitro.}

A microscopia eletrônica de varredura detectou colonização de bactérias em todos os tratamentos. Entretanto, houve variações quantitativas.

As fotos da Figura 29 mostram a distribuição espacial das bactérias na região do caule da mandioca: (A) Esc de B. pumilus mostrou a abundância de células bacterianas colonizando a região interna do caule em meio de cultura MS (Murashige \& Skoog); (B) Vista panorâmica da colonização de B. pumilus no tecido vascular do caule em meio de cultura MS; (C) Controle realizado em meio de cultura MS sem a presença de células bacterianas; (D) Corte transversal da região interna do caule onde observou-se a colonização do B. pumilus.

As fotos da Figura 30 mostram a larga distribuição das bactérias na região das raízes de mandioca. (A) B. pumilus mostrou o potencial de colonização na região vascular da raiz em meio MS; (B) Vista panorâmica da região vascular da raiz onde observou-se colonização de B. pumilus em meio MS; (C) Controle realizado em meio MS sem a presença de células bacterianas; (D) Corte transversal da região interna da raiz onde observou - se a colonização do B. pumilus. 
A s fotos da Figura 31 mostram a distribuição das bactérias nos tecidos vasculares, xilema. (A) B. pumilus mostrou o potencial de colonização na região vascular do xilema na raiz, em outro tratamento; (B) Vista panorâmica da região vascular, xilema, na raiz onde observou-se colonização de B. pumilus; (C) Corte transversal da região do xilema em outro tratamento; (D) Corte longitudinal da região do xilema na raiz em outro tratamento; (E) Controle realizado em meio MS sem a presença de células bacterianas na região do caule; (F) Corte transversal da região interna da raiz onde não observou a colonização do B. pumilus, Controle.

Bacillus pumilus colonizou tanto a rizosfera como o caule, concordando com diversos trabalhos, principalmente, $P$. fluorescens e $P$. putida (Lugtemberg et al., 2001). Portanto, Bacillus pumilus, indicaram colonizadoras eficientes e boas candidatas como agentes no biocontrole.

A microscopia eletrônica de varredura permitiu a observação da superfície de certas estruturas, proporcionando assim uma visão tridimensional do objeto, diferentemente do microscópio eletrônico tradicional, que só permite a observação de cortes finíssimos da estrutura estudada. 


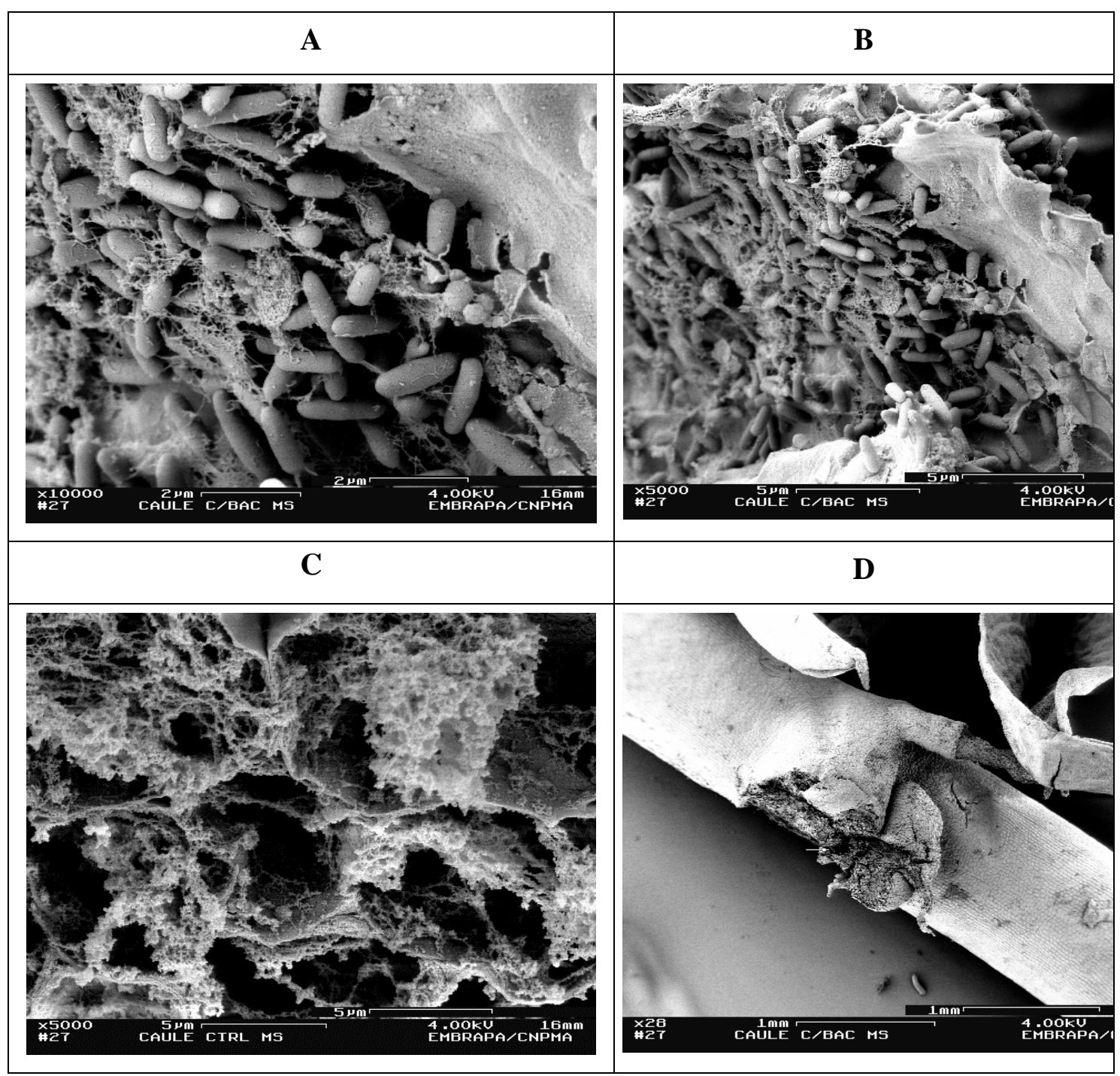

Figura 29 - Microscopia eletrônica de varredura da região do caule. (A) Esc de B. pumilus mostrou a abundância de células bacterianas colonizando a região interna do caule em meio de cultura MS; (B) Vista panorâmica da colonização de B. pumilus no tecido vascular do caule em meio de cultura MS; (C) Controle realizado em meio de cultura MS sem a presença de células bacterianas; (D) Corte transversal da região interna do caule onde observou a colonização do B. pumilus. 


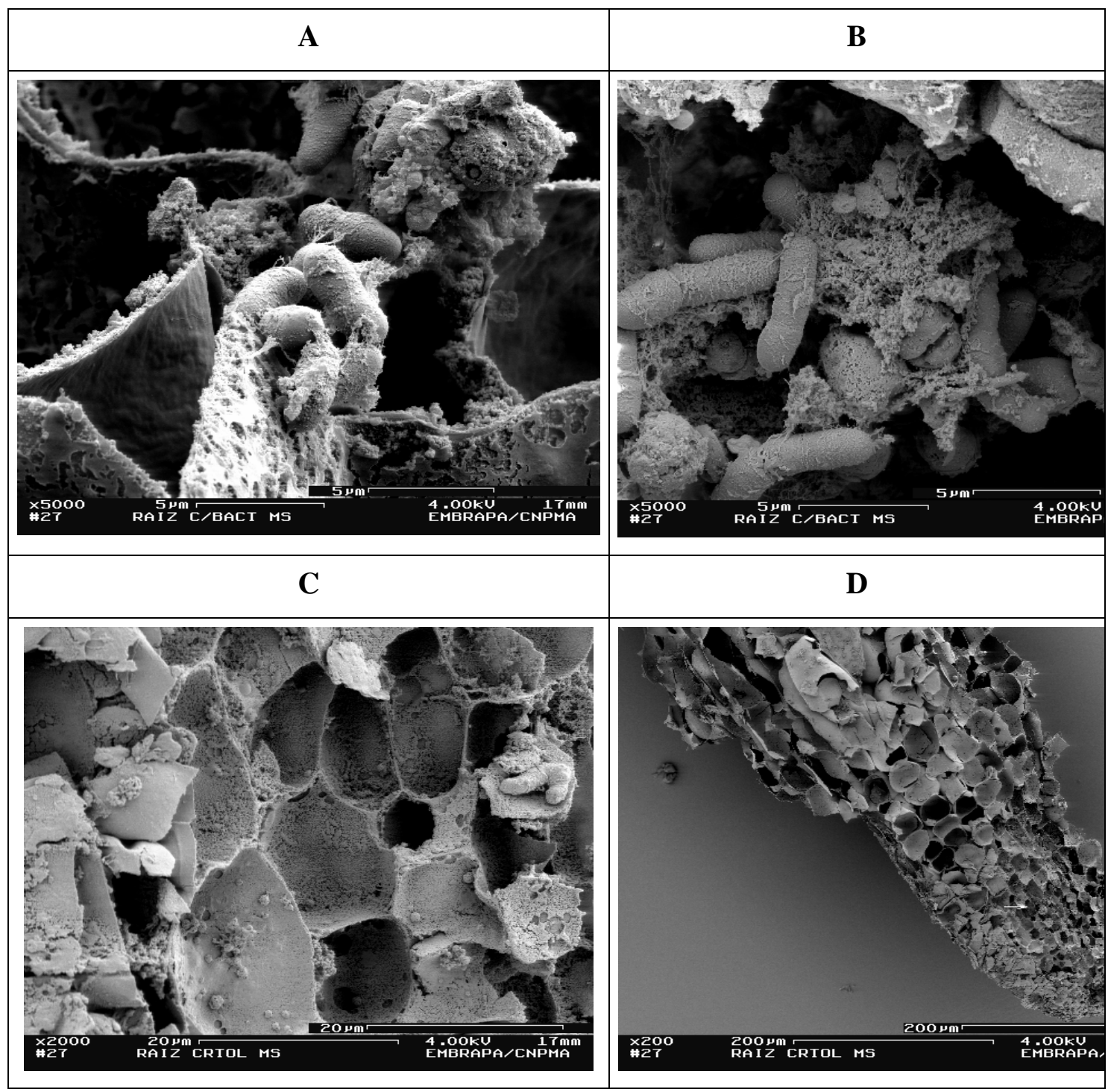

Figura 30 - Microscopia eletrônica de varredura da região da raiz. (A) B. pumilus mostrou o potencial de colonização na região vascular da raiz, em meio MS; (B) Vista panorâmica da região vascular da raiz onde observou colonização de B. pumilus em meio MS; (C). Controle realizado em meio MS sem a presença de células bacterianas; (D) Corte longitudinal da região interna da raiz onde observou - se a colonização do B. pumilus. 


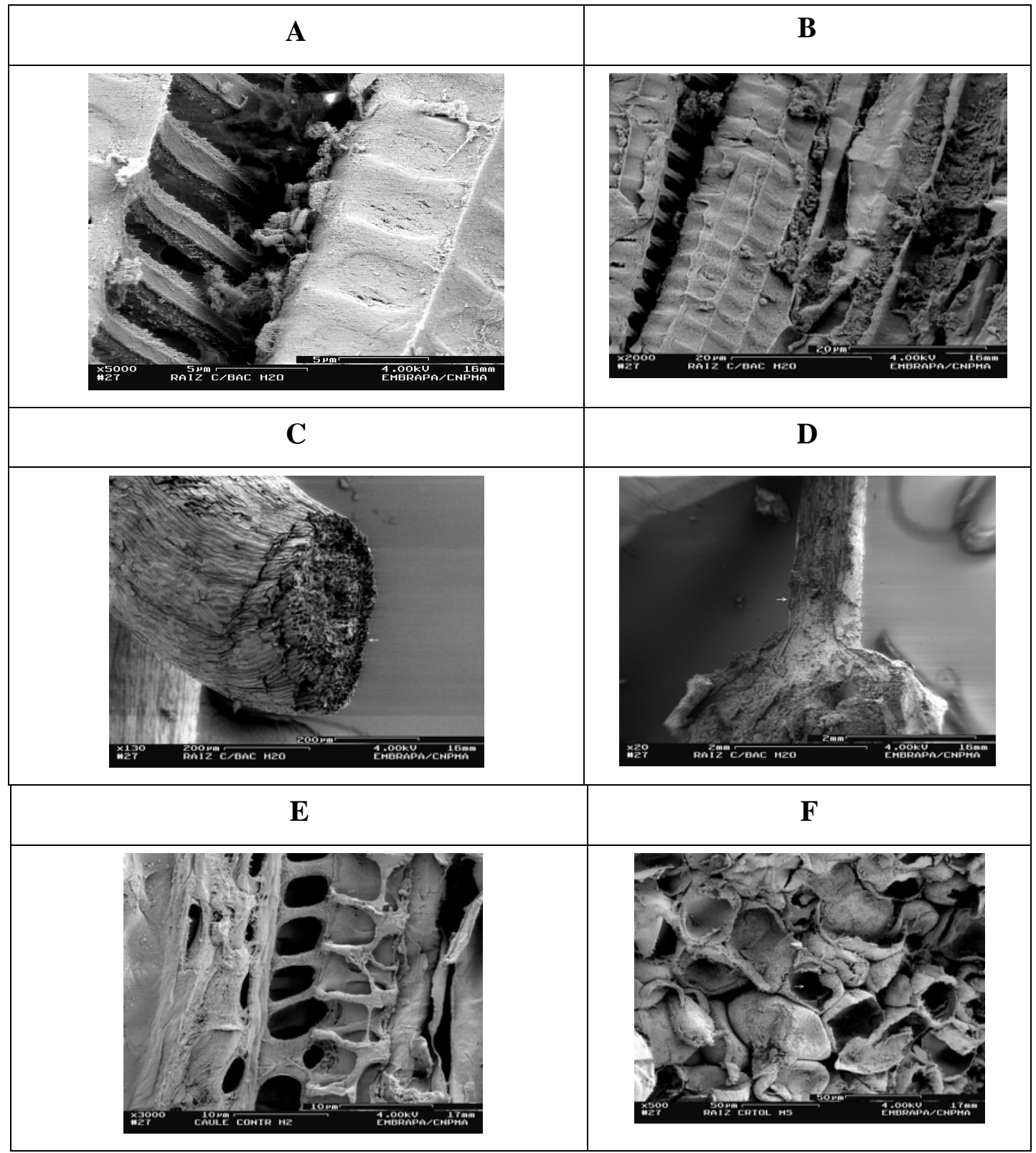

Figura 31 - Microscopia eletrônica de varredura da região da raiz e do caule. (A) B. pumilus mostrou o potencial de colonização na região vascular do xilema na raiz, em outro tratamento; (B) Vista panorâmica da região vascular do xilema na raiz onde observou-se colonização de B. pumilus; (C) Corte transversal da região do xilema em outro tratamento; (D) Corte longitudinal da região do xilema na raiz em outro tratamento; (E) Controle realizado em meio MS sem a presença de células bacterianas no caule; (F) Corte transversal da região interna da raiz onde não observou - se a colonização do B. pumilus, Controle. 


\section{CONCLUSÕES}

- A diversidade de bactérias endofíticas (67 isolados, 18 gêneros) encontrada na cultura de sub-existência estudada, mostrou que sistema agrícola não intensivo propicia condições favoráveis para o desenvolvimento de um grande número de bactérias.

- Dois terços das bactérias endofíticas isoladas da mandioca inibiram a germinação do micélio de fungos fitopatogênicos ( $R$. solani, P. aphanidermatum e S. rolfsii) causadores de podridões radiculares de mandioca, possivelmente devido à produção de compostos bioativos.

- A bactéria endofítica de mandioca B. pumilus apresentou o maior efeito inibitório de crescimento dos fungos patogênicos testados.

- Os solventes diclorometano e acetato de etila apresentaram alta eficiência na obtenção de extratos celulares de bactérias com atividades antifúngicas.

- O método cromatográfico CL/EM apresentou capacidade de resolução suficiente que permitiu a identificação da substância antifúngica pumilacidina produzida pela bactéria endofítica B. pumilus.

- O endofitismo do B. pumilus na mandioca pode ser facilmente comprovado pela análise estrutural dos tecidos vegetais por meio de microscopia eletrônica de varredura. 
ANEXO 
Meios de cultura e Soluções

Meios de Cultura utilizados para Isolamento e Cultivo de Bactérias Endofíticas (King et al., 1948) Tryptona Soya Agar (TSA) e amido caseína.

Tryptona Soya Agar (500mL)

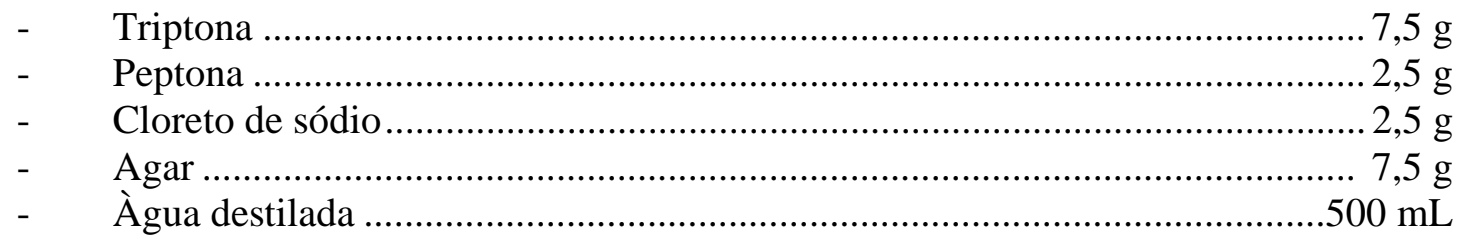

Amido Caseína (500 mL)

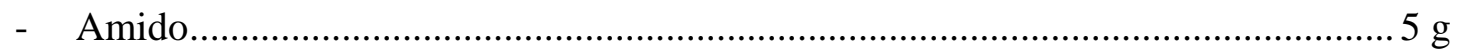

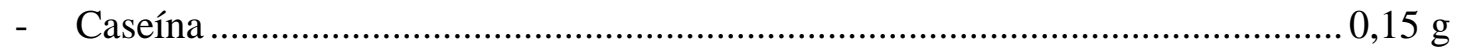

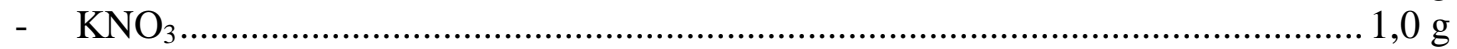

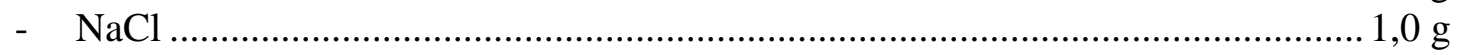

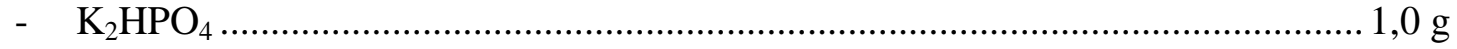

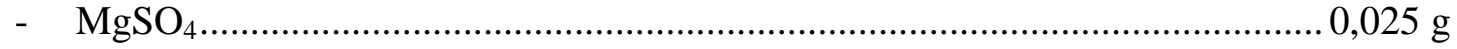

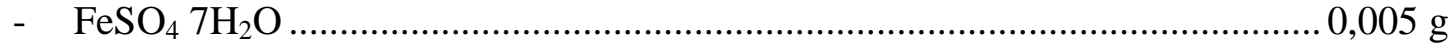

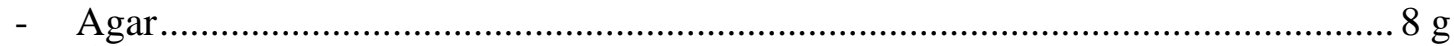

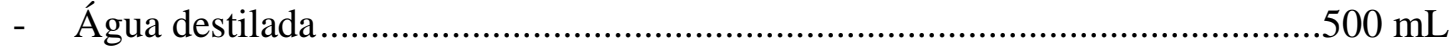

Meio de cultura utilizado para o teste de antagonismo (King et al., 1948).

Batata - Dextrose- Ágar (500mL)

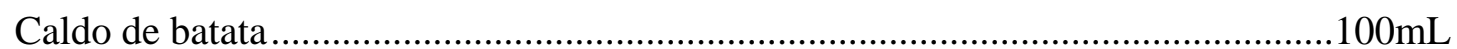

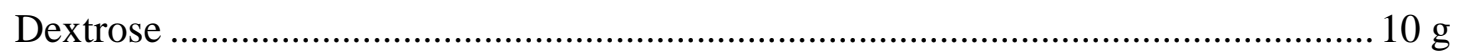

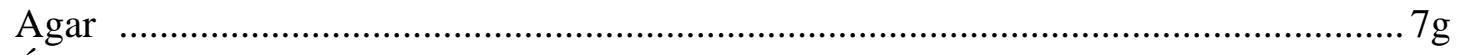

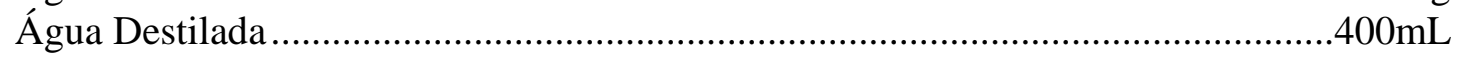

Meios de cultura utilizados para análise de Biomassa

Meio líquido Caldo Nutriente CN

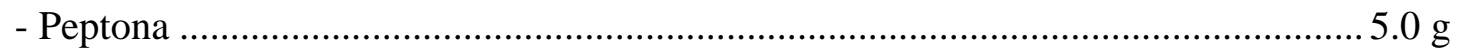

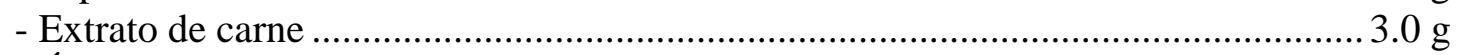

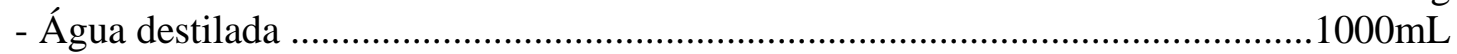

Meio líquido Nutriente Agar-NA

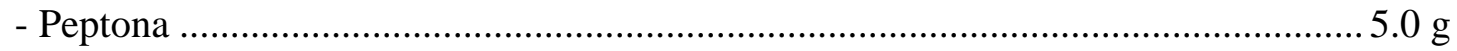

- Extrato de carne ....................................................................................................... $3.0 \mathrm{~g}$ 
- Água destilada

$1000 \mathrm{~mL}$

Meio líquido LB (LURIO \& Burrous, 1957).

- Triptona $10.0 \mathrm{~g}$

- Extrato de levedura . $.5 \mathrm{~g}$

- $\mathrm{NaCl}$ $5.0 \mathrm{~g}$

- Água destilada $1000 \mathrm{~mL}$

Meio líquido Czapek - Dox

- $\mathrm{NaNO}_{3}$ $3.0 \mathrm{~g}$

- $\mathrm{KeHPO}_{4}$ $1.0 \mathrm{~g}$

- $\mathrm{MgSO}_{4}$ $0.5 \mathrm{~g}$

- $\mathrm{FeSO}_{4} \cdot 7 \mathrm{H}_{2} \mathrm{O}$ $0.01 \mathrm{~g}$

- Sacarose $30.0 \mathrm{~g}$

- Água destilada $.1000 \mathrm{~mL}$

Meio líquido Batata Dextrose -BD

- Caldo de batata. $200 \mathrm{~mL}$

- Dextrose $20 \mathrm{~g}$

- Agua destilada $800 \mathrm{~mL}$

Composição do meio de cultura de Murashige \& Skoog (1962).

\begin{tabular}{|c|c|}
\hline \multirow[t]{2}{*}{ CONSTITUINTES } & \multirow[t]{2}{*}{ QUANTIDADES mg/L } \\
\hline & \\
\hline $\mathrm{NH}_{4} \mathrm{NO}_{3}$ & 1650 \\
\hline $\mathrm{KNO}_{3}$ & 1900 \\
\hline $\mathrm{CaCl}_{2} 2 \mathrm{H}_{2} \mathrm{O}$ & 440 \\
\hline $\mathrm{MgSO}_{4} 7 \mathrm{H}_{2} \mathrm{O}$ & 370 \\
\hline $\mathrm{KH}_{2} \mathrm{PO}_{4}$ & 170 \\
\hline $\mathrm{KI}$ & 0,83 \\
\hline $\mathrm{H}_{3} \mathrm{BO}_{3}$ & 6,2 \\
\hline $\mathrm{MnSO}_{4} 4 \mathrm{H}_{2} \mathrm{O}$ & 22,3 \\
\hline $\mathrm{ZnSO}_{4} 7 \mathrm{H}_{2} \mathrm{O}$ & 8,6 \\
\hline $\mathrm{Na}_{2} \mathrm{MoO}_{4} 2 \mathrm{H}_{2} \mathrm{O}$ & 0,25 \\
\hline $\mathrm{CuSO}_{4} 5 \mathrm{H}_{2} \mathrm{O}$ & 0,025 \\
\hline $\mathrm{CoCl}_{2} 6 \mathrm{H}_{2} \mathrm{O}$ & 0,025 \\
\hline $\mathrm{FeSO}_{4} 7 \mathrm{H}_{2} \mathrm{O}$ & 27,8 \\
\hline $\mathrm{Na}_{2}$ EDTA $2 \mathrm{H}_{2} \mathrm{O}$ & 37,3 \\
\hline \multicolumn{2}{|r|}{ ORGÂNICOS } \\
\hline Inositol & 100 \\
\hline Tiamina $\mathrm{Hl}$ & 0,1 \\
\hline Piridoxina $\mathrm{HCl}$ & 0,5 \\
\hline Ácido Nicotínico & 0,5 \\
\hline Glicina & 2,0 \\
\hline Sacarose & 30000 \\
\hline Ágar & $0,8 \%$ \\
\hline
\end{tabular}




\section{REFERÊNCIAS BIBLIOGRÁFICAS}

ADACHI, K.; NAKATANI, M.; MOCHIDA, H. Isolation an endophytic diazotroph, Klebsiella oxytoca, from sweet potato stems in Japan. Soil Science and Plant Nutrition, v. 48, p. 889-895, 2002.

ANDRADE-MONTEIRO, C.; MACCHERONI JÚNIOR., W.; ROSSI, A.; MARTINEZ-ROSSI, N. M. A simplified method for the isolation of high molecular weight DNA from Aspergillus nidulans. Brazilian Journal of Genetics, v. 17, p. 447-448, 1994.

ARAÚJO, W. L.; MACCHERONI JÚNIOR, W.; AGUILLAR-VILDOSO, C. I.; BARROSO, P. A. V.; SARIDKIS, H. O.; AZEVEDO, J. L. Variability and interations between endophytic bacteria and fungi isolated from leaf tissues of citrus rootstocks. Canadian Journal of Microbiology, v. 47, p. 229-236, 2001.

ARAÚJO, W. L.; MARCON, J.; MACCHERONI JÚNIOR, W.; VAN ELSAS, J. D.; VAN VUURDE, J. W. L.; AZEVEDO, J. L. Diversity of endophytic bacterial populations and theirs interactions with Xylella fastidiosa in Citrus plants: Applied and Environmental Microbiology, v. 68, p. 4906-4914, 2002.

ASAKA, O.; SHODA, M. Biocontrol of Rhizoctonia solani damping-off of tomato with Bacillus subtilis RB14. Applied and Environmental Microbiology, v. 62, p. 408415, 1996. 
AZEVEDO, J. L. Biodiversidade microbiana e potencial biotecnológico. In: MELO, I. S. de; AZEVEDO, J. L. (Ed.). Ecologia microbiana. Jaguariúna: Embrapa Meio Ambiente, 1998a. cap.18, p. 445-461.

AZEVEDO, J. L. Microrganismos endofíticos. In: MELO, I. S. de; AZEVEDO, J. L. (Ed.). Ecologia microbiana. Jaguariúna: Embrapa Meio Ambiente, 1998b. cap. 4, p. 445-461.

AZEVEDO, J. L.; ARAÚJO, W. L.; MACCHERONI JÚNIOR, W. Importância dos microrganismos endofíticos no controle de insetos. In: MELO, I. S. de; AZEVEDO, J. L. (Ed.). Controle biológico. Jaguariúna: Embrapa Meio Ambiente, 2000. v. 3, p. 57-94.

BAI, Y.; DÁOUST, F.; SMITH, D. L.; DRISCOLL, B. T. Isolation of plant-growthpromoting Bacillus strains from soybean root nodules. Canadian Journal of Microbiology, v. 48, p. 230-238, 2002.

BARBIERI, R. L.; McSHANE, P. M.; RYAN, K. J. Constituents of cigarette smoke inhibit human granulosa cell aromatase. Fertility and Sterility,v. 46, p. 232-236, 1986.

BEIJERINCK AND VAN DELDEN. Rhizobium radiobacter. International Journal of Systematic Bacteriology, v. 51, p.99, 1902.

BELL, C. R.; DICKIE, G. A.; CHAN, J. W. Y. F. Variable response of bacteria isolated from grapevine xylem to control grape crown gall disease in plant. American Journal of Enology and Viticulture, v. 46, p. 499-508, 1995. 
BELL, C. R.; DICKIE, G. A.; HARVEY, W. L. G.; CHAN, J. M. Y. F. Endophytic bacteria in grapevine. Canadian Journal of Microbiology, v. 41, p. 46-53, 1995.

BENHAMOU, N; GAGNE, S; LE QUERE, D.; DEHBI, L. Bacterial-mediated induced resistance in cucumber: Beneficial effect of the endophytic bacterium Serratia plymuthica on the protection against infection by Pythium ultimum. Phytopathology, v. 90, p. 45-56, 2000.

BENHAMOU, N.; KLOEPPER, J. W.; QUADT-HALLMAN, A.; TUZUN, S. Induction of defense-related ultrastructural modifications in pea root tissues inoculated with endophytic bacteria. Plant Physiology, v. 112, p. 919-929, 1996.

BOCHOW, H. Mode of action and practical use of the Bacillus subtilis as complex acting bioproduct. In: MANKA, M. (Ed.). Environmental biotic factors in integrated plant disease control. Poznan: The Polish Phytopathological Society, 1995. p. 97-104.

BURDMAN, S.; SARIG, S.; KIGEL, J. Y.; OKON, Y. Field inoculation of common bean ( $P$. vulgaris) and chickpea (Cicer arietinum) with Azospirillum brasilense strain Cd. Symbiosis, v. 21, p. 41-48, 1996.

BURGES, H. D.; COPPLESTONE, J. F.; DUBITSKIJ, A.; HAMON, J.; MACKENZIE, D. W. R.; ROGOFF, M. H.; TAYLOR, T. A.; TINSLEY, T. W.; VANDEKAR, M.; VERNES, A. J. M.; WRIGHT, A. E. Mammalian safety of microbial agents for vector control: a WHO Memorandum. Bulletin of the World Health Organization, v. 59, p. 857-863, 1981.

CAMACHO, F. J.; LISTON, A. Population structure and genetic diversity of Botrychium pumicola (Ophioglossaceae) based on inter-simple sequence repeats (ISSR). American Journal of Botany, v. 88, p. 1065-1070, 2001. 
CAVALCANTE, V. A.; DÖBEREINER, J. A new acid tolerant nitro-gen-fixing bacterium associated with sugarcane. Plant and Soil, v. 108, p. 23-31, 1988.

CHEN, C.; BAUSKE, E. M.; MUSSON, G.; RODRÍGUEZ-KÁBANA, R.; KLOEPPER, J. W. Biological control of Fusarium wilt on cotton by use of endophytic bacteria. Biological Control, v. 5, p. 83-91, 1995.

CLAUS, D.; BERKELEY, R. C. W. Genus Bacillus Cohn. In: SNEATH, P. H. A. (Ed.). Bergey's manual of systematic bacteriology. Baltimore: Williams \& Wilkins, 1986. v. 2, p.110-539.

COOK, R. J. Plant health and the sustainability of agriculture, with special reference to disease control by beneficial microorganisms. Biological Agriculture \& Horticulture, v. 3, p. 211-232, 1986.

COLLINS. H. C; BRAGA. L. G; BONATO, S. P. Introdução a métodos cromatográficos. Campinas: Editora da UNICAMP, 1990. p. 9-279.

DUIJFT, B. J.; GIANINAZZI-PEARSON, V.; LEMANCEAU, P. Involvement of the outer membrane lipopolysaccharides in the endophytic colonization of tomato roots by biocontrol Pseudomonas fluorescenses strain WCS417r. New Phytologist, v. 135, p. 325-334, 1997.

DUNLEAVY, J. Control of damping-off of sugar beet by Bacillus subtilis. Phytopathology, v. 45, p. 252-258, 1955.

ELBELTAGY, A.; NISHIOKA, K.; SATO, T.; SUZUKI, H.; YE, B.; HAMADA, T.; ISAWA, T, MITSUI, H.; MINAMIZAWA, K. Endophytic colonization and in plant nitrogen fixation by a Herbaspirillum sp. isolated from wild rice species. Applied and Environmental Microbiology, v. 67, p. 5285-5293, 2001. 
ELVIRA-RECUENCO, M.; VAN VUURDE, J. W. L. Natural incidence of endophytic bacteria in pea cultivars under field conditions. Canadian Journal of Microbiology, v. 46, p.1036-1041, 2000.

FAHEY, J. W. Endophytic bacteria for the delivery of agrochemicals to plants. In: CUTLER, H. G. (Ed.). Biologically active natural products: potential use in agriculture. New York: American Chemical Society, 1988. p. 120-128. (ACS Symposium Series, 380).

FRAVEL, D. R.; MAROIS, J. J.; LUMSDEN, R. D.; CONNICK, W. J. Jr. Encapsulation of potential biocontrol agents in an alginate clay matrix. Phytopathology, v. 69, p. 64-68, 1985.

FROMMEL, M. I.; NOWAK, J.; LAZAROVITS, G. Growth enhancement and developmental modifications of in vitro growth potato (Solanum tuberosum spp. tuberosum as affected by a nonfluorescent Pseudomonas sp. Plant Physiology, v. 96, p. 928-936, 1991.

GAGNE, D.; PONS, M.; PHILIBERT, D. RU 38486: a potent anti-glucocorticoid $\underline{\text { in}}$ $\underline{\text { vitro }}$ and in vivo. Journal of Steroid Biochemistry, v. 23, p. 247, 1985.

GANTAR, M.; KERBY, N. W.; ROWELL, P. Colonization of wheat (Triticum vulgare L.) by $\mathrm{N}_{2}$-fixing cyanobacteria. II. An ultrastrutural study. New Phytologist, v. 118, p. 485-492, 1991. 
GILLIS, M.; DÖBEREINER, J.; POT, B.; GOOR, M.; FALSEN, E.; HOSTE, B.; REINHOLD, B.; KERSTERS, K. Taxonomic relationships between [Pseudomonas] rubrisubalbicans, some clinical isolates (EF group 1), Herbaspirillum seropedicae and [Aquaspirillum] autotrophicum. In: POLSINELLI, M.; MATERASSI, R.; VICENZINI, M. Nitrogen fixation associated with non-legumes. Melbourne: s. ed., 1990. p. 293-294.

GOEL, A.; ELLENBERGER, T.; FRANK-KAMENETSKII, M. D.; HERSCHBACH, D. Unifying themes in DNA replication: reconciling single molecule kinetic studies with structural data on DNA polymerases. Journal of Biomolecular Structure and Dynamics, v. 19, p. 571-84, 2002.

GOMES, R. Efeito da solarização do solo no nemátodo Heterodera carotae Jones, 1950. In: JORNADAS NACIONAIS DE PLÁSTICOS PARA A AGRICULTURA, 1988, Anais... [s.l.: s.n.], p.10.

GOMES, J. C. Considerações sobre adubação e calagem para a cultivar da mandioca. Revista Brasileira de. Mandioca, v. 6, p. 99-107, 1987.

HABIB, M. E. M.; FERNANDES, W. D.; FAVARO JÚNIOR., A.; ANDRADE, C. F. S. Eficiência do feromônio de agregação e inseticidas químicos no combate ao bicudo Anthonomus grandis Boheman, 1843 (Coleoptera, Curculionidae). Revista de Agricultura, v. 59, p. 239-251, 1984.

HALLMANN, J.; QUADT-HALLMANN, A.; MAHAFFEE, W. F.; KLOEPPER, J. W. Bacterial endophytes in agricultural crops. Canadian Journal of Microbiology, v. 43, p. 895-914, 1997. 
HALVERSON, L. J.; HANDELSMAN, J. Enhancement of soybean nodulation by Bacillus cereus UW85 in the field and in a growth chamber. Applied and Environmental Microbiology, v. 57, p. 2767-2770, 1991.

HEUER, H.; KRSEK, M.; BAKER, P.; SMALLA, K.; WELLINGTON, E.M. Analysis of actinomycete communities by specific amplification of genes encoding 16S rRNA and gel-electrophoretic separation in denaturing gradients. Applied and Environmental Microbiology, v. 63, p. 3233-32341, 1997.

HOLLIS, J. P. Bacteria in healthy potato tissue. Phytopathology, v. 41, p. 350-367, 1949.

HOWELER, R. H. Mineral nutrition and fertilization of cassava (Manihot esculenta Crantz). Cali: Centro Internacional de Agricultura Tropical, 1981. 52 p.

HOWELER, R. H. Cassava. In: PLUCKNETT, D. L.; SPRAGUE, H. B. (Ed.). Detecting mineral nutrient deficiencies in tropical and temperate crops. Boulder: Westview, 1989. p. 167-177.

HUANG, J.S. Ultrastructure of bacterial penetration in plants. Annual Review Phytopathology, v. 24, p. 141-157, 1986.

HUREK, T.; REINHOLD-HUREK, B.; VAN MONTAGU, M.; KELLENBERGER, E. Root colonization and systemic spreading of Azoarcus sp. Strain BH72 in grasses. Journal of Bacteriology, v. 176, p. 1913-1923, 1994.

JACOBS, M. J.; BUGDEE, W. M.; GABRIELSON, D. A. Enumeration, location, and characterization of endophytic bacteria within sugar beet roots. Canadian Journal of Botany, v. 63, p. 1262-1265, 1985. 
JAMES, E. K.; REIS, V. M.; OLIVARES, F. L.; BALDANI, J. I.; DÖBEREINER, J. Infection of sugar cane by the nitrogen-fixing bacterium Acetobacter diazotrophicus. Journal of Experimental Botany, v. 45, p. 757-766, 1994.

JIMENEZ-SALGADO, T.; FUENTES-RAMIREZ, L. E.; TAPIA-HERNANDEZ, A.; MASCARUA-ESPARZA, M. A.; MARTINEZ-ROMERO, E.; CABALLEROMELLADO, J. Coffea arabica L., a new host plant for Acetobacter diazotrophicus, and isolation of other nitrogen-fixing acetobacteria. Applied and Environmental Microbiology, v. 63, p. 3676-83, 1997.

KING, J. V.; CAMPELL, J. J. R.; EAGLES, B. A. The mineral requeriment for fluorescein production. Canadian Journal of Research, v. 26, p. 514-519, 1948.

KITAJIMA, E. W.; LEITE, B. Curso introdutório de microscopia eletrônica de varredura. 2. ed. Piracicaba: NAP/MEPA- Esalq/USP, 1999. 46 p.

KLISH, M. A.; LAX, A. R.; BLAND, J. M.; SCHARFENSTEIN, L. L. Jr. Influence os iturin A on mycelial weight and aflatoxin production by Aspergillus flavus and Aspergillus parasiticus in shake culture. Mycopathologia, v. 123, p. 35-38, 1993.

KLOEPPER, J. W.; RODRUGUES-KABANA, R.; ZEHNDER, G. W.; MURPHY, F.; SIKODA, E.; FERNANDEZ, C. Plant root bacterial interactions in biological control of soilborne disases and potential extension to systemic and foliar diseases. Australian Plant Pathology, v. 28, p. 21-26, 1999.

KREBS, B.; HÖDING, B.; KÜBART, S.; ALEMAYEHU-WORKIE, M.; JUNGE, H.; SCHMIEDEKNECHT, G.; GROSCH, R.; BOCHOW, H.; HEVESI, M. Use of Bacillus subtilis as biological control agent. I. Activities and characterization of Bacillus subtilis strains. Journal of Plant Disease and Protection, v. 105, p. 18-1 97, 1998. 
KRYWIENCZYK, J.; DULMAGE, H. T.; FAST, P. G. Occurrence of two serologically distinct groups within Bacillus thuringiensis serotype 3ab variety kurstaki. Journal of Invertebrate Pathology, v. 37, p. 372-375, 1978.

KLUGER, M. J. Fever: role of pyrogens and cryogens. Physiological Reviews, v. 71, p. 93-127, 1991.

KOBAYASHI, D.Y.; PALUMBO, J. D. Bacterial endophytes and their effects on plants and uses in agriculture. In: BACON, C. W.; WHITE, J. F. (Ed.). Microbial endophytes. Washington: Marcel Dekker, 2000. p. 199-233.

LALANDE, R.; BISSONNETTE, N.; COUTLÉE, D.; ANTOUN, H., Identification of rhizobacteria from maize and determination of their plant-growth promoting potential. Plant and Soil, v. 115, p. 7-11, 1989.

LAMPEL, J. S.; GANTES, G. L.; DIMACK, M. B.; KELLY, J. L.; ANDERSON, J. J.; URATANI, B. B.; FOUEKE-JR, J. S.; TURNER, J. T. Integrate cloning, expression, and stability of the crylA (C) gene Bacillus thurigiensis sbsp. Kurstaki in a recombinant strain of Clavitobacter Xyli sbsp, cynodontis. Applied and Environmental Microbiology, v. 60, p. 501-508, 1994.

LEBBADI, M.; GÁLVEZ, A.; MAQUEDA, M.; MARTÍNEZ-BUENO, M.; VALDIVIA, E. Fungicin M4: a narrow spectrum peptide antibiotic from Bacillus licheniformis M-4. Journal of Applied Bacteriology, v. 77, p. 4953, 1994.

LEIFERT, C.; WORKMAN, S.; LI, H. Antibiotic production and biocontrol activity by Bacillus subtilis CL27 and Bacillus pumilus CL45 . Journal of Applied Bacteriology, v. 78, p. 97 108, 1995. 
LOEFFLER, W.; TSCHEN, S.-M.; VANITTANAKOM, N.; KUGLER, M.; KNORPP, E.; HSIEH, T.-F.; WU, T.-G. Antifungal effects of bacilysin and fengymycin from Bacillus subtilis F-29-3: a comparison with activities of other Bacillus antibiotics. Journal of Phytopathology, v. 115, p. 204-213, 1986.

LUGTENBERG, B. J. J; DEKKERS, L.; BLOEMBERG, G. V. Molecular determinants of rhizosphere colonization by Pseudomonas. Annual Review of Phytopathology, v. 39, p. 461-490, 2001.

MAHAFFEE, W. F.; KLOEPPER, J. W.; VAN VUURDE, J. W. L.; VAN DER WOLF, J. M.; VAN DEN BRINK, M. Endophytic colonization of Phaseolus vulgaris by Pseudomonas fluorescens strain 89B-27 and Enterobacter asburiae strain JM22. In: RYDER, M. H.; STEPHENS, P. M.; BOWEN, G. D. (Ed.). Improving plant productivity in rhizosphere bacteria. New York: CSIRO, 1997. p. 180.

MANNINGER, E.; ANTAL, M. Rhizobium and other bacteria in the root nodules of leguminous plants. I. Sterilization of the surface of root nodules of Soja max. Zentralblatt fur Bakteriologie, Parasitenkunde, Infektionskrankheiten und Hygiene, v. 124, p. 684-687, 1970.

MCKEEN, C. D.; REILLY, C. C.; PUSEY, P. L. Production and partial characterization of antifungal substances antagonistic to Monilinia fructicola. Phytopathology, v. 76, p. 136-138, 1986.

McINROY, J. A.; KLOEPPER, J. W. Analysis of population densities and identification of endophytic bacteria of maize and cotton in the field. Bulletin SROP, v. 14, p. 328-331, 1991. 
MELO, I. S. de. Agentes microbianos de controle de fungos fitopatogênicos. In: MELO, I. S. de; AZEVEDO, J. L. (Ed.). Controle biológico. Jaguariúna: Embrapa Meio Ambiente, 1998. v. 1, p. 17-67.

MISAGHI, I. J.; DONNDELINGER, C. R. Endophytic bacteria in symptom-free coton plants. Phytopathology, v. 80, p. 808-811, 1990.

M'PIGA, P.; BELANGER, R. R.; PAULITZ, T. C.; BENHAMOU, N. Increased resistance to Fusarium oxysporum f. sp. radicis-lycopersici in tomato plants treated with the endophytic bacterium Pseudomonas fluorescens strain 63-28. Physiological and Molecular Plant Pathology, v. 50, p. 301-320, 1997.

MURASHIGE, T.; SKOOG, F. A revised medium for rapid growth and bioassays with tobacco tissue cultures. Physiologia Plantarum, v. 15, p. 473-497, 1962.

MUKHOPADHYAY, S.; SINGH, M.; CARTER, J. I.; FRANKLIN, M.; OLVER, R. E. The terapy antibiótical with anti-pseudomonal de Nebulised no fibrosis cystic; analysed with benefits ad males. Thorax, v. 51, p. 364-368, 1996.

NAKANO, M. M.; ZUBER, P. Molecular biology of antibiotic pro duction in Bacillus. CRC Critical Reviews in Biotechnology, v. 10, p. 223-240, 1990.

NÜBEL, U.; ENGELEN, B.; FELSKE, A.; SNAIDR, J.; WIESHUBER, A.; AMANN, R.I.; LUDWIG, W.; BACKHAUS, H. Sequence heterogeneities of genes encoding 16S rRNAs in Paenibacillus polymyxa detected by temperature gradient gel electrophoresis. Journal of Bacteriology, v. 178, p. 5636-5643, 1996. 
OEHRLE, N. W.; KARR, D. B.; KREMER, R. J.; EMERICH, D. W. Enhanced attachment of Bradyrhizobium japonicum to soybean through reduced root colonization of internally seedborne microorganisms. Canadian Journal of Microbiology, v. 46, p. 600-606, 2000.

PEDERSEN, J. C.; DAMGAARD, P. H.; EILENBERG, E.; HANSEN, B. M. Dispersal of Bacillus thuringiensis var. kurstaki in an experimental cabbage field. Canadian Journal of Microbiology, v. 41, p. 118-125, 1995.

PEREIRA, J. O. Fungos endofíticos dos hospedeiros tropicais Stylosanthes guinamensis e Musa cavandish. Piracicaba, 1993. 105 p. Tese (Doutorado) - Escola Superior de Agricultura Luiz de Queiroz, Universidade de São Paulo.

PETRINI, O. Fungal endophyte of tree leaves. In: ANDREWS, J.; HIRANO, S. S. (Ed.). Microbial ecology of leaves. Washington: Springer Verlag, 1991. p. 179-97.

PHAE, C. G.; SHODA, M.; KUBOTA, H. Suppressive effect of Bacillus subtilis and its products on phytopathogenic microorganisms. Journal of Fermentation and Bioengineering, v. 69, p. 1-7, 1990.

PLEBAN, S.; CHERNIN, L.; CHET, I. Chitinolytic activity of an endophytic strain of Bacillus cereus. Letters in Applied Microbiology, v. 25, p. 284-288, 1997.

PLEBAN, S.; INGEL, F.; CHET, I. Control of Rhyzoctonia solani and Sclerotium rolfsii in greenhouse using endophytic Bacillus spp. European Journal of Plant Pathology, v. 101, p. 665-672, 1995. 
POTERA, C. From bacteria: a new weapon against fungal infection. Science, v. 265, p. $605,1994$.

QUADT-HALLMANN, A.; KLOEPPER, J. W. Immunological detection and localization of the cotton endophyte Enterobacter asburiae JM22 in different plant species. Canadian Journal of Microbiology, v. 42, p. 1144-1154, 1996.

REINHOLD, B.; HUREK, T. Location of diazotrophs in the interior with special attention to the kallar grass association. Plant and Soil, v. 110, p. 259-268, 1988.

REITER, B.; PFEIFER, U.; SCHWAB, H.; SESSITSCH, A. Response of endophytic bacterial communities in potato plants to infection with Erwinia carotovora subsp. atroseptica. Applied and Environmental Microbiology, v. 68, p. 2261-2268, 2002.

SILO-SUH, L. A.; LETHBRIDGE, B. J.; RAFFEL, S. J.; HE, H.; CLARDY, J.; HANDELSMAN, J. Biological activities of two fungistatic antibiotics produced by Bacillus cereus UW85. Applied and Environmental Microbiology, v. 60, p. 20232030, 1994.

SIVAN, A.; ELAD, Y.; CHET, I. Biological control effects of a new isolate of Trichoderma harzianum on Pythium aphanidermatum. Phytopathology, v. 74, p. 498-501, 1984.

SPRENT, J. I.; DE FARIA, S. M. Mechanisms of infection of plants by nitrogen fixing organisms. Plant and Soil, v. 110, p. 157-165, 1988.

STABB, E. V.; JACOBSON, L. M.; HANDELSMAN, J.; ZWITTERMICIN, A. Producing strains of Bacillus cereus from diverse soils. Applied and Environmental Microbiology, v. 60, p. 4404-4412, 1994. 
STACKEBRANDT, E.; GOEBEL, B.M. Taxonomic note: a place for DNA-DNA reassociation and 16S rRNA sequence analysis in the present species definition in bacteriology. International Journal of Systematic and Bacteriology, v. 44, p. 846849, 1994.

STURZ, A. V.; CHRISTIE, B. R.; MATHESON, B. G. Association of bacterial endophyte populations from red clover and potato crops with potential for beneficial allelopathy. Canadian Journal of Microbiology, v. 44, p. 162-167, 1998.

STURZ, A. V.; CHRISTIE, B. R.; NOWAK, J. Bacterial endophytes: potential role in developing sustainable system of crop production. CRC Critical Reviews in Plant Scienses, v. 19, p. 1-30, 2000.

STURZ, A. V.; CHRISTIE, B. R.; MATHESON, B. G.; NOWAK, J. Biodiversity of endophytic bacteria which colonize red clover nodules, roots, stems and foliage and their influence on host growth. Biology and Fertility of Soils, v. 25 , p. 13-19, 1997.

SY, A.; GIRAUD, E.; JOURAND, P.; GARCIA, N.; WILLEM, A.; DE LAJUDIE, P.; PRIN, Y.; NEYRA, M.; GILLIS, M.; BOIVIN-MASSON, B.; DREYFUS, B. Methylotrophic Methylobacterium bacteria nodulate and fix nitrogen in symbiosis with legumes. Journal of Bacteriology, v. 183, p. 214-220, 2001.

URATANI, Y. Immunoaffinity purification and reconstitution of sodium-coupled branched-chain amino acid carrier of Pseudomonas aeruginosa. Journal of Biological Chemistry, v. 267, p. 5177-5183, 1992.

VANKOVA, J.; PURRINI, K. Natural epizootics caused by bacilli of the species Bacillus thuringiensis and Bacillus cereus. Zeitschrift fuer Angewandt Entomologie, v. 88, p. 216-221, 1979. 
WEBBER, J. A natural control of Dutch elm disease. Nature, v. 292, p. 449-451, 1981.

WEBER, O. B; BALDANI, J. I.; DÖBEREINER, J. Bactérias diazotróficas em mudas de bananeira. Pesquisa Agropecuária Brasileira, v. 35, p. 2277-2285, 2000.

WEBSTER, G.; GOUGH, C.; VASSE, J.; BATCHELOR, C. A.; O'CALLAGHAN, K. J.; KOTHARI, S. L.; DAVEY, M. R.; DÉNARIÉ, J.; COCKING, E. C. Interactions of rhizobia with wheat and rice. Plant and Soil, v. 194, p. 115-122, 1997.

XU, L. M.; GE, C.; CUI, Z.; LI, J.; FAN, H. Bradyrhizobium liaoningense sp. nov., isolated from the root nodules of soybeans. International of Journal of Systematic Bacteriology, v. 45, p. 706-711, 1995.

YANG, C.; CROWLEY, D. E.; MENGE, J. A. 16S rDNA fingerprinting of rhizosphere bacterial communities associated with healthy and Phytophthora infected avocado roots. FEMS Microbiology Ecology, v. 35, p. 129-136, 2001.

YOU, C.; ZHOU, F. Non-nodular endorhizospheric nitrogen fixation in wetland rice. Canadian Journal of Microbiology, v. 35, p. 403-408, 1989.

YOU, C. B.; LIN, M.; FANG, X. J.; SONG, W. Attachment of Alcaligenes to rice roots. Soil Biology and Biochemistry, v. 27, p. 463-466, 1995.

ZINNIEL, D. K.; LAMBRECHT, N.; HARRIS, B.; FENG, Z.; KUEZMARSKI, D.; HIGLEY, P.; ISHIMARU, C. A.; ARUNAKUMARI, A.; BARLETTA, R. G.; VIDAVER, A. K. Isolation and characterization of endophytic colonizing bacteria from agronomic crops and prairie plants. Applied and Environmental Microbiology, v. 68 , p. 2198-2208, 2002. 